\title{
Capacities of the Nutrition Sector in Senegal
}

Gabriel Deussom N., Victoria Wise, Marie Solange Ndione, Aida Gadiaga

Cellule de Lutte contre la Malnutrition

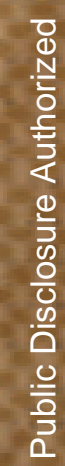

*

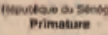

CLM

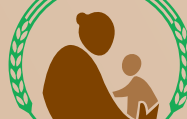





\section{Capacities of the Nutrition Sector in Senegal}

December 2018

Gabriel Deussom N., Victoria Wise, Marie Solange Ndione, Aida Gadiaga

Analysis \& Perspective: 15 Years of Experience in the Development of Nutrition Policy in Senegal

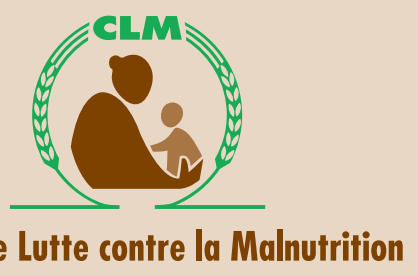


(C) 2018 International Bank for Reconstruction and Development / The World Bank

1818 H Street NW

Washington DC 20433

Telephone: $202-473-1000$

Internet: www.worldbank.org

Attribution-Please cite the work as follows: Deussom N., Gabriel, Victoria Wise, Marie Solange Ndione, and Aida Gadiaga. 2018. "Capacities of the Nutrition Sector in Senegal." Analysis \& Perspective: 15 Years of Experience in the Development of Nutrition Policy in Senegal. World Bank, Washington, DC; CLM, Dakar, Sénégal. License: Creative Commons Attribution CC BY 3.0 IGO

This work is a product of the staff of The World Bank with external contributions. The findings, interpretations, and conclusions expressed in this work do not necessarily reflect the views of The World Bank, its Board of Executive Directors, or the governments they represent. The World Bank does not guarantee the accuracy of the data included in this work. The boundaries, colors, denominations, and other information shown on any map in this work do not imply any judgment on the part of The World Bank concerning the legal status of any territory or the endorsement or acceptance of such boundaries.

Rights and Permissions

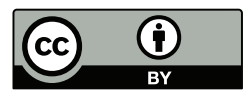

The material in this work is subject to copyright. Because The World Bank encourages dissemination of its knowledge, this work may be reproduced, in whole or in part, for noncommercial purposes as long as full attribution to this work is given.

Any queries on rights and licenses, including subsidiary rights, should be addressed to World Bank Publications, The World Bank Group, 1818 H Street NW, Washington, DC 20433, USA; fax: 202-522-2625; e-mail: pubrights@worldbank.org.

Cover photo: Adama Cissé/CLM

Cover design: The Word Express, Inc. 


\section{Acknowledgments}

his assessment was conducted with the technical support of the World Bank, REACH and UNICEF within the framework of support to the Senegalese government and the Nutrition Coordination Unit (CLM). The team of consultants would like to specifically thank the Assessment Steering Committee composed of CLM, World Bank, UNICEF, and REACH which assisted the team throughout its work. Our deep gratitude also goes to all institutions and people at the central, regional and community level for their generous contribution to the accomplishment of this diagnostic through their availability and collaboration. We express our appreciation to the entire team of the National Executive Bureau for Nutrition (BEN), the Regional Executive Bureau for Nutrition (BER) and to members of the CLM for their incommensurable support to the organization of data gathering and the sectoral analysis units for their openness and invaluable contribution.

Reviewers. We are grateful to all reviewers of the reports of the series-Elodie Becquey (IFPRI), Patrick Eozenou (World Bank), Dominic Haazen (World Bank), Derek Headey (IFPRI), Abdoulaye Ka (CLM), Jakub Kakietek (World Bank), Ashi Kohli Kathuria (World Bank), Christine Lao Pena (World Bank), Biram Ndiaye (UNICEF), Jumana Qamruddin (World Bank), Claudia Rokx (World Bank). They each generously dedicated their time and effort, and their invaluable input played an important role in the evolution of the series.

Partners. We would also like to give thanks to the following members of the task force of development partner organizations, who provided guidance on the conceptualization, implementation and finalization of the series: Sophie Cowpplibony (REACH), Aissatou Dioum (UNICEF), George Fom Ameh (UNICEF), Julie Desloges (Government of Canada), Aida Gadiaga (WFP), Laylee Moshiri (UNICEF), Aminata Ndiaye (Government of Canada), Marie Solange N'Dione (Independent Consultant), and Victoria Wise (REACH).

Client. Finally, our greatest appreciation is extended to the dedicated staff of the CLM, whose work is chronicled in the series, and the thousands of health workers and volunteers who are daily delivering life-saving nutrition services to vulnerable populations throughout Senegal.

This work was conducted under the guidance of Menno Mulder-Sibanda (Task Team Lead and Senior Nutrition Specialist, World Bank). The series was prepared by Andrea L. Spray (Consultant), Janice Meerman (Consultant), and Aline Deffry (Consultant). Aaron Buchsbaum (World Bank) led on publishing and dissemination, along Laura Figazzolo (Consultant).

Information regarding the financial support for the series is provided at the end of the report. 


\section{About the Series}

he government of Senegal, through the Cellule de Lutte contre la Malnutrition (Nutrition Coordination Unit) (CLM) in the Prime Minister's Office is embarking on the development of a new Plan Stratégique Multisectoriel de Nutrition (Multisectoral Strategic Nutrition Plan) (PSMN), which will have two broad focus areas: (1) expanding and improving nutrition services; and (2) a reform agenda for the sector. The reform agenda will include policy reorientation, governance, and financing of the PSMN. The PSMN will discuss the framework and timeline for the development of a nutrition financing strategy, which will require specific analysis of the sector spending and financial basis, linking it to the coverage and quality of nutrition services.

Senegal is known for having one of the most effective and far-reaching nutrition service delivery systems in Africa. Chronic malnutrition has dropped to less than 20 percent, one of the lowest in continental Sub-Saharan Africa. Government ownership of the nutrition program has grown from US $\$ 0.3$ million a year in 2002 to US $\$ 5.7$ million a year in 2015 , increasing from approximately 0.02 percent to 0.12 percent of the national budget. Yet, these developments have not led to enhanced visibility of nutrition-sensitive interventions in relevant sectors such as agriculture, education, water and sanitation, social protection, and health. The absence of nutrition-sensitive interventions in the relevant sectors, combined with the recent series of external shocks, has favored continued fragmentation of approaches, discourse, and interventions that address nutrition. In addition, there is no overall framework for investment decision making around nutrition, which puts achievements made to date in jeopardy. Meanwhile, nutrition indicators are stagnating and other issues with major implications (such as low birth weight, iron deficiency anemia, maternal undernutrition, and acute malnutrition) have received little or no attention.

A review of policy effectiveness can help raise the importance of these issues, including household and community resilience to food and nutrition insecurity shocks, as a new priority in nutrition policy development. This series of analytical and advisory activities, collectively entitled Analysis \& Perspective: 15 Years of Experience in the Development of Nutrition Policy in Senegal ("the series"), aims to support the government of Senegal in providing policy and strategic leadership for nutrition. Further, the series will inform an investment case for nutrition (The Case for Investment in Nutrition in Senegal) that will: (1) rationalize the use of resources for cost-effective interventions; (2) mobilize actors and resources; (3) strengthen the visibility of nutrition interventions in different sectors; and (4) favor synergy of interventions and investments.

The series was produced with guidance from a task force of development partner organizations under the leadership of the World Bank, and in close collaboration with the CLM. The task force comprised representatives from the following organizations: Government of Canada, REACH, UNICEF and the World Bank. 


\section{Documents in the series:}

\begin{tabular}{|c|c|}
\hline Report & Description \\
\hline $\begin{array}{l}\text { Nutrition Situation in Senegal } \\
\text { Marc Nene }\end{array}$ & $\begin{array}{l}\text { An analysis of the nutritional status of key demographic groups } \\
\text { in Senegal, including the geographic and sociodemographic } \\
\text { inequalities in nutrition outcomes and their determinants. }\end{array}$ \\
\hline $\begin{array}{l}\text { Evolution of Nutrition Policy in } \\
\text { Senegal } \\
\text { Andrea L. Spray }\end{array}$ & $\begin{array}{l}\text { An historical analysis of the nutrition policy landscape in Senegal, } \\
\text { including the evolution of nutrition policies and institutions and } \\
\text { their respective implications for programming and prioritization of } \\
\text { interventions. }\end{array}$ \\
\hline $\begin{array}{l}\text { Political Economy of Nutrition } \\
\text { Policy in Senegal } \\
\text { Ashley M. Fox }\end{array}$ & $\begin{array}{l}\text { An analysis of the policy and political levers that can be used } \\
\text { in Senegal to foster government leadership and galvanize the } \\
\text { intersectoral coordination needed to mainstream nutrition into } \\
\text { government policies and programs, and effectively, efficiently, and } \\
\text { sustainably deliver nutrition interventions. }\end{array}$ \\
\hline $\begin{array}{l}\text { Nutrition Financing in Senegal } \\
\text { Marie-Jeanne Offosse } N \text {. }\end{array}$ & $\begin{array}{l}\text { An analysis of the allocated funding to nutrition interventions in } \\
\text { Senegal from } 2016 \text { to } 2019 \text {, estimates of budgetary capacity for } \\
\text { financing nutrition by government, and estimated costs for selected } \\
\text { high-impact interventions. }\end{array}$ \\
\hline $\begin{array}{l}\text { Capacities of the Nutrition } \\
\text { Sector in Senegal } \\
\text { Gabriel Deussom N., Victoria } \\
\text { Wise, Marie Solange Ndione, } \\
\text { Aida Gadiaga }\end{array}$ & $\begin{array}{l}\text { An analysis of the organizational and institutional capacities for } \\
\text { addressing nutrition in Senegal, covering the CLM, key ministries, } \\
\text { and other stakeholders contributing to improvements in nutrition at } \\
\text { the central, regional, and local levels. }\end{array}$ \\
\hline $\begin{array}{l}\text { Cost and Benefits of Scaling } \\
\text { Up Nutrition Interventions in } \\
\text { Senegal } \\
\text { Christian Yao }\end{array}$ & $\begin{array}{l}\text { Analysis of the relative costs and effectiveness of alternative } \\
\text { scenarios for scaling up nutrition interventions in Senegal over the } \\
\text { five years covering the PSMN. }\end{array}$ \\
\hline $\begin{array}{l}\text { Risks for Scaling Up Nutrition } \\
\text { in Senegal } \\
\text { Babacar } \mathrm{Ba}\end{array}$ & $\begin{array}{l}\text { Analysis of the potential risks to the scale-up of nutrition in } \\
\text { Senegal, their likelihood of occurrence, potential impact, and } \\
\text { potential mitigation measures. }\end{array}$ \\
\hline $\begin{array}{l}\text { A Decade of World Bank } \\
\text { Support to Senegal's Nutrition } \\
\text { Program } \\
\text { Denise Vaillancourt }\end{array}$ & $\begin{array}{l}\text { The World Bank Independent Evaluation Group Project } \\
\text { Performance Assessment Report, which evaluates the extent to } \\
\text { which World Bank operations supporting nutrition in Senegal from } \\
2002-14 \text { achieved their intended outcomes and draws lessons to } \\
\text { inform future investments. }\end{array}$ \\
\hline
\end{tabular}




\section{Acronyms}

\begin{tabular}{|c|c|c|c|}
\hline Acronym & English & Acronyme & Français \\
\hline ABAP & Annual Budget Action Plan & PABA & Plan d'Action du Budget Annuel \\
\hline ACF & Action Against Hunger & ACF & Action Contre la Faim \\
\hline AEC & $\begin{array}{l}\text { Community Executing } \\
\text { Agency }\end{array}$ & AEC & $\begin{array}{l}\text { Agence d'Exécution } \\
\text { Communautaire }\end{array}$ \\
\hline AECID & $\begin{array}{l}\text { Spanish Agency for } \\
\text { International Co-operation } \\
\text { and Development }\end{array}$ & AECID & $\begin{array}{l}\text { Agence Espagnole pour la } \\
\text { Coopération Internationale et le } \\
\text { Développement }\end{array}$ \\
\hline AfDB & African Development Bank & BAD & $\begin{array}{l}\text { Banque Africaine de } \\
\text { Développement }\end{array}$ \\
\hline AGETIP & $\begin{array}{l}\text { Executing Agency for Public } \\
\text { Works and Employment }\end{array}$ & AGETIP & $\begin{array}{l}\text { Agence d'Exécution des } \\
\text { Travaux d'Intérêt Public }\end{array}$ \\
\hline AGIR & $\begin{array}{l}\text { Global Alliance for Resilience } \\
\text { (AGIR)—Sahel and West } \\
\text { Africa }\end{array}$ & AGIR & $\begin{array}{l}\text { Alliance Globale pour la } \\
\text { Résilience (AGIR)—Sahel et } \\
\text { Afrique de l'Ouest }\end{array}$ \\
\hline AGRICE & $\begin{array}{l}\text { Agriculture for Chemistry and } \\
\text { Energy }\end{array}$ & AGRICE & $\begin{array}{l}\text { Agriculture pour la Cimie et } \\
\text { l'Energie }\end{array}$ \\
\hline ANPECTP & $\begin{array}{l}\text { National Agency of Early } \\
\text { Childhood Development and } \\
\text { Reception Center }\end{array}$ & ANPECTP & $\begin{array}{l}\text { Agence Nationale de la Petite } \\
\text { Enfance et de la Case des } \\
\text { Tout-Petits }\end{array}$ \\
\hline ANSD & $\begin{array}{l}\text { National Statistics and } \\
\text { Demography Agency }\end{array}$ & ANSD & $\begin{array}{l}\text { Agence Nationale de } \\
\text { la Statistique et de la } \\
\text { Démographie }\end{array}$ \\
\hline ARAF & $\begin{array}{l}\text { Regional Association of } \\
\text { Fatick Farmers }\end{array}$ & ARAF & $\begin{array}{l}\text { Association Régionale des } \\
\text { Agriculteurs de la Région }\end{array}$ \\
\hline ADR & $\begin{array}{l}\text { Regional Development } \\
\text { Agency }\end{array}$ & ADR & $\begin{array}{l}\text { Agence de Développement } \\
\text { Régional }\end{array}$ \\
\hline ARI & Acute respiratory infection & IRA & Infection respiratoire aiguë \\
\hline ARMP & $\begin{array}{l}\text { Public Procurement } \\
\text { Regulating Authority }\end{array}$ & ARMP & $\begin{array}{l}\text { Autorité de Réglementation des } \\
\text { Marchés Publics }\end{array}$ \\
\hline AWP & Annual work plan & PTA & Plans de travail annuels \\
\hline BACDI & $\begin{array}{l}\text { Program Support Unit to the } \\
\text { Development Program of } \\
\text { the Embassy of Canada to } \\
\text { Senegal }\end{array}$ & BACDI & $\begin{array}{l}\text { Bureau d'Appui à Section } \\
\text { Coopération de l'Ambassade du } \\
\text { Canada au Sénégal }\end{array}$ \\
\hline $\mathrm{BCC}$ & $\begin{array}{l}\text { Behavior change } \\
\text { communication }\end{array}$ & $\mathrm{CCC}$ & $\begin{array}{l}\text { Communication pour le } \\
\text { changement de comportement }\end{array}$ \\
\hline BEN & National Executive Bureau & BEN & Bureau Exécutif National \\
\hline BER & Regional Executive Bureau & BER & Bureau Exécutif Régional \\
\hline
\end{tabular}




\begin{tabular}{|c|c|c|c|}
\hline Acronym & English & Acronyme & Français \\
\hline СВО & $\begin{array}{l}\text { Community-Based } \\
\text { Organization }\end{array}$ & OCB & $\begin{array}{l}\text { Organisation Communautaire } \\
\text { de Base }\end{array}$ \\
\hline CDS & $\begin{array}{l}\text { Departmental follow-up } \\
\text { committee }\end{array}$ & CDS & Comité départemental de suivi \\
\hline CEP & Studies and Planning Unit & CEP & $\begin{array}{l}\text { Cellule d'Etude et de } \\
\text { Planification }\end{array}$ \\
\hline CFA & $\begin{array}{l}\text { Financial Community of } \\
\text { Africa }\end{array}$ & CFA & $\begin{array}{l}\text { Communauté Financière } \\
\text { d'Afrique }\end{array}$ \\
\hline C-IMCI & $\begin{array}{l}\text { Community Integrated } \\
\text { Management of Childhood } \\
\text { Illnesses }\end{array}$ & PCIME-C & $\begin{array}{l}\text { Prise en Charge Intégrée } \\
\text { des Maladies de I'Enfant } \\
\text { Communautaire }\end{array}$ \\
\hline $\mathrm{CL}$ & Local government collectives & $\mathrm{CL}$ & Collectivités locales \\
\hline CLM & Nutrition Coordination Unit & CLM & $\begin{array}{l}\text { Cellule de Lutte contre la } \\
\text { Malnutrition }\end{array}$ \\
\hline CLTS & $\begin{array}{l}\text { Community-led Total } \\
\text { Sanitation }\end{array}$ & ATPC & $\begin{array}{l}\text { Assainissement Total Piloté par } \\
\text { la Communauté }\end{array}$ \\
\hline CMAM & $\begin{array}{l}\text { Community Management of } \\
\text { Acute Malnutrition }\end{array}$ & PECMA & $\begin{array}{l}\text { Prise en Charge } \\
\text { Communautairede la } \\
\text { Malnutrition Aiguë }\end{array}$ \\
\hline CNSA & $\begin{array}{l}\text { National Food Security } \\
\text { Council }\end{array}$ & CNSA & $\begin{array}{l}\text { Conseil National sur la Sécurité } \\
\text { Alimentaire }\end{array}$ \\
\hline COSFAM & $\begin{array}{l}\text { Senegalese Committee for } \\
\text { Food Fortification }\end{array}$ & COSFAM & $\begin{array}{l}\text { Conseil Sénégalais pour la } \\
\text { Fortification des Aliments en } \\
\text { Micronutriments }\end{array}$ \\
\hline CRCCIS & $\begin{array}{l}\text { Regional Coordination } \\
\text { Committee for Salt lodization } \\
\text { Control }\end{array}$ & CRCCIS & $\begin{array}{l}\text { Comité Régional de } \\
\text { Coordination et de Contrôle de } \\
\text { l'iodation du sel }\end{array}$ \\
\hline CREN & $\begin{array}{l}\text { Center of Recovery and } \\
\text { Nutritional Education }\end{array}$ & CREN & $\begin{array}{l}\text { Centre de Réhabilitation et d' } \\
\text { Éducation Nutritionnelle }\end{array}$ \\
\hline CRF & French Red Cross & $\mathrm{CRF}$ & Croix-Rouge Française \\
\hline CRS & $\begin{array}{l}\text { Regional Follow-up } \\
\text { Committee }\end{array}$ & CRS & Comité Régional de Suivi \\
\hline DAGE & $\begin{array}{l}\text { General Administration and } \\
\text { Equipment }\end{array}$ & DAGE & $\begin{array}{l}\text { Direction de l'Administration } \\
\text { Générale et de l'Equipement }\end{array}$ \\
\hline DAN & $\begin{array}{l}\text { Division of Food and } \\
\text { Nutrition }\end{array}$ & DAN & $\begin{array}{l}\text { Division de l'Alimentation et de } \\
\text { la Nutrition }\end{array}$ \\
\hline DANSE & $\begin{array}{l}\text { Division of Food, Nutrition, } \\
\text { and Child Survival }\end{array}$ & DANSE & $\begin{array}{l}\text { Division de l'Alimentation et de } \\
\text { la Nutrition et de la Survie de } \\
\text { l'Enfant }\end{array}$ \\
\hline DAPSA & $\begin{array}{l}\text { Agricultural Statistics } \\
\text { Analysis and Forecast } \\
\text { Department }\end{array}$ & DAPSA & $\begin{array}{l}\text { Direction de l'Analyse et de } \\
\text { la Prévision des Statistiques } \\
\text { Agricoles }\end{array}$ \\
\hline
\end{tabular}




\begin{tabular}{|c|c|c|c|}
\hline Acronym & English & Acronyme & Français \\
\hline DCMS & $\begin{array}{l}\text { School Health Checks } \\
\text { Division }\end{array}$ & DCMS & $\begin{array}{l}\text { Division du Contrôle Médical } \\
\text { Scolaire }\end{array}$ \\
\hline DFATD & $\begin{array}{l}\text { Department of Foreign } \\
\text { Affairs, Trade and } \\
\text { Development, Australia }\end{array}$ & DFATD & $\begin{array}{l}\text { Département des Affaires } \\
\text { Etrangères, du Commerce et du } \\
\text { Développement, Australie }\end{array}$ \\
\hline DFID & $\begin{array}{l}\text { Department of International } \\
\text { Development, United } \\
\text { Kingdom }\end{array}$ & DFID & $\begin{array}{l}\text { Département du } \\
\text { Développement International, } \\
\text { Royaume-Uni }\end{array}$ \\
\hline DHIS2 & $\begin{array}{l}\text { District Health Information } \\
\text { Software } 2\end{array}$ & DHIS2 & $\begin{array}{l}\text { Système d'information sanitaire } \\
\text { au niveau du district }\end{array}$ \\
\hline DPPD & $\begin{array}{l}\text { Multiannual Expenditure } \\
\text { Planning Document }\end{array}$ & DPPD & $\begin{array}{l}\text { Document de Programmation } \\
\text { Pluriannuelle des Dépenses }\end{array}$ \\
\hline DPRE & $\begin{array}{l}\text { Department of Educational } \\
\text { Planning and Reform }\end{array}$ & DPRE & $\begin{array}{l}\text { Direction de la Planification et } \\
\text { de la Réforme de l'Education }\end{array}$ \\
\hline DRDR & $\begin{array}{l}\text { Regional Rural Development } \\
\text { Departments }\end{array}$ & DRDR & $\begin{array}{l}\text { Directions Régionales de } \\
\text { Développement Rural }\end{array}$ \\
\hline DSE & Division of Child Survival & DSE & Division de la Survie de l'Enfant \\
\hline DSRP & $\begin{array}{l}\text { Poverty Reduction Strategy } \\
\text { Paper }\end{array}$ & DSRP & $\begin{array}{l}\text { Document de Stratégie de } \\
\text { Réduction de la Pauvreté }\end{array}$ \\
\hline DSRSE & $\begin{array}{l}\text { Department of Reproductive } \\
\text { Health and Child Survival }\end{array}$ & DSRSE & $\begin{array}{l}\text { Direction de la Santé de la } \\
\text { Reproduction et de la Survie de } \\
\text { l'Enfant }\end{array}$ \\
\hline EBF & Exclusive breastfeeding & AME & Allaitement maternel exclusif \\
\hline $\mathrm{ECHO}$ & $\begin{array}{l}\text { European Commission-Civil } \\
\text { Protection \& Humanitarian } \\
\text { Aid Operations }\end{array}$ & $\mathrm{ECHO}$ & $\begin{array}{l}\text { Direction Générale pour } \\
\text { la Protection Civile et les } \\
\text { Opérations d'Aide Humanitaire } \\
\text { Européennes de la Commission } \\
\text { Européenne }\end{array}$ \\
\hline ECOWAS & $\begin{array}{l}\text { Economic Community of } \\
\text { West African States }\end{array}$ & CEDEAO & $\begin{array}{l}\text { Communauté économique des } \\
\text { États de l'Afrique de l'Ouest }\end{array}$ \\
\hline EFP & Essential family practices & PFE & $\begin{array}{l}\text { Promotion des comportements } \\
\text { clés favorable à une bonne } \\
\text { nutrition }\end{array}$ \\
\hline ENFEFS & $\begin{array}{l}\text { National Family and Social } \\
\text { Economy Training School }\end{array}$ & ENFEFS & $\begin{array}{l}\text { Ecole Nationale de Formation } \\
\text { en Economie Familiale et } \\
\text { Sociale }\end{array}$ \\
\hline FAO & $\begin{array}{l}\text { Food and Agriculture } \\
\text { Organization of the United } \\
\text { Nations }\end{array}$ & FAO & $\begin{array}{l}\text { Organisation des Nations } \\
\text { Unies pour l'Alimentation et } \\
\text { l'Agriculture }\end{array}$ \\
\hline FPR & Financial Progress Report & RSF & Rapport de Suivi Financier \\
\hline GAIN & $\begin{array}{l}\text { Global Alliance for Improved } \\
\text { Nutrition }\end{array}$ & GAIN & $\begin{array}{l}\text { Alliance Mondiale pour } \\
\text { l'Amélioration de la Nutrition }\end{array}$ \\
\hline
\end{tabular}




\begin{tabular}{|c|c|c|c|}
\hline Acronym & English & Acronyme & Français \\
\hline GS & Government of Senegal & GS & Gouvernement de Sénégal \\
\hline $\mathrm{HKI}$ & Helen Keller International & $\mathrm{HKI}$ & Helen Keller International \\
\hline IA & School Inspection Office & $\mathrm{IA}$ & Inspection d'Académie \\
\hline IDB & Islamic Development Bank & BID & $\begin{array}{l}\text { Banque Islamique du } \\
\text { Développement }\end{array}$ \\
\hline IEC & $\begin{array}{l}\text { Information, Education and } \\
\text { Communication }\end{array}$ & IEC & $\begin{array}{l}\text { Information, Éducation et } \\
\text { Communication }\end{array}$ \\
\hline IECD & $\begin{array}{l}\text { Integrated Early Childhood } \\
\text { Development }\end{array}$ & DIPE & $\begin{array}{l}\text { Développement Intégré de la } \\
\text { Petite Enfance }\end{array}$ \\
\hline IEF & $\begin{array}{l}\text { Education and Training } \\
\text { Inspections }\end{array}$ & IEF & $\begin{array}{l}\text { Inspections de l'éducation et de } \\
\text { la formation }\end{array}$ \\
\hline IFAD & $\begin{array}{l}\text { International Fund for } \\
\text { Agricultural Development }\end{array}$ & FIDA & $\begin{array}{l}\text { Fonds International de } \\
\text { Développement Agricole }\end{array}$ \\
\hline IFDC & $\begin{array}{l}\text { International Fertilizer } \\
\text { Development Center }\end{array}$ & IFDC & $\begin{array}{l}\text { Centre International de } \\
\text { Développement des Engrais }\end{array}$ \\
\hline IFPRI & $\begin{array}{l}\text { International Food Policy } \\
\text { Research Institute }\end{array}$ & IFPRI & $\begin{array}{l}\text { Institut International de } \\
\text { Recherche sur les Politiques } \\
\text { Alimentaires }\end{array}$ \\
\hline INGO & $\begin{array}{l}\text { International } \\
\text { Nongovernmental } \\
\text { Organization }\end{array}$ & ONGI & $\begin{array}{l}\text { Organisation Non- } \\
\text { Gouvernementale } \\
\text { Internationales }\end{array}$ \\
\hline IOCA & $\begin{array}{l}\text { Institutional and } \\
\text { Organizational Capacity } \\
\text { Assessment }\end{array}$ & ECIO & $\begin{array}{l}\text { Évaluation des capacités } \\
\text { institutionnelles et } \\
\text { organisationnelles }\end{array}$ \\
\hline ITA & Food Technology Institute & ITA & $\begin{array}{l}\text { Institut de Technologie } \\
\text { Alimentaire }\end{array}$ \\
\hline IYCF & $\begin{array}{l}\text { Infant and Young Child } \\
\text { Feeding }\end{array}$ & ANJE & $\begin{array}{l}\text { Alimentation du Nourrisson et } \\
\text { du Jeune Enfant }\end{array}$ \\
\hline JICA & $\begin{array}{l}\text { Japanese International } \\
\text { Cooperation Agency }\end{array}$ & JICA & $\begin{array}{l}\text { Agence de Coopération } \\
\text { Internationale du Japon }\end{array}$ \\
\hline JSE & Child Survival Days & JSE & Journées de Survie de l'Enfant \\
\hline KOICA & $\begin{array}{l}\text { Korean International } \\
\text { Cooperation Agency }\end{array}$ & KOICA & $\begin{array}{l}\text { Agence Coréenne de } \\
\text { Coopération Internationale }\end{array}$ \\
\hline LOASP & $\begin{array}{l}\text { Agro-Sylvo-Pastoral } \\
\text { Orientation Law }\end{array}$ & LOASP & $\begin{array}{l}\text { Loi d'Orientation } \\
\text { Agro-Sylvo-Pastorale }\end{array}$ \\
\hline LPDN & Nutrition Policy Letter & LPDN & $\begin{array}{l}\text { Lettre de Politique de } \\
\text { Développement de la Nutrition }\end{array}$ \\
\hline LPSERN & $\begin{array}{l}\text { Natural Resources Sectoral } \\
\text { Policy Letter }\end{array}$ & LPSERN & $\begin{array}{l}\text { Lettre de Politique Sectorielle } \\
\text { de l'Environnement et des } \\
\text { Ressources Naturelles }\end{array}$ \\
\hline MAER & $\begin{array}{l}\text { Ministry of Agriculture and } \\
\text { Rural Equipment }\end{array}$ & MAER & $\begin{array}{l}\text { Ministère de l'Agriculture et de } \\
\text { l'Équipement Rural }\end{array}$ \\
\hline MAM & Moderate Acute Malnutrition & MAM & Malnutrition Aiguë Modérée \\
\hline
\end{tabular}




\begin{tabular}{|c|c|c|c|}
\hline Acronym & English & Acronyme & Français \\
\hline MDG & $\begin{array}{l}\text { Millennium Development } \\
\text { Goals }\end{array}$ & OMD & $\begin{array}{l}\text { Objectifs du Millénaire pour le } \\
\text { Développement }\end{array}$ \\
\hline MEFP & $\begin{array}{l}\text { Ministry of Finance, the } \\
\text { Economy and Planning }\end{array}$ & MEFP & $\begin{array}{l}\text { Ministère de l'Économie, des } \\
\text { Finances et du Plan }\end{array}$ \\
\hline MEN & Ministry of Education & MEN & $\begin{array}{l}\text { Ministère de l'Éducation } \\
\text { Nationale }\end{array}$ \\
\hline MEPA & $\begin{array}{l}\text { Ministry of Livestock and } \\
\text { Animal Husbandry }\end{array}$ & MEPA & $\begin{array}{l}\text { Ministère de l'Élevage et des } \\
\text { Productions Animales }\end{array}$ \\
\hline $\mathrm{Ml}$ & Micronutrient Initiative & $\mathrm{MI}$ & $\begin{array}{l}\text { Initiative pour les } \\
\text { Micronutriments }\end{array}$ \\
\hline MSAS & $\begin{array}{l}\text { Ministry of Health and Social } \\
\text { Action }\end{array}$ & MSAS & $\begin{array}{l}\text { Ministère de la Santé et de } \\
\text { l'Action Sociale }\end{array}$ \\
\hline N4G & Nutrition for Growth & $N 4 G$ & Nutrition pour la Croissance \\
\hline NASAN & $\begin{array}{l}\text { New Alliance for Food } \\
\text { Security and Nutrition }\end{array}$ & NASAN & $\begin{array}{l}\text { Nouvelle Alliance pour la } \\
\text { Sécurité Alimentaire et la } \\
\text { Nutrition }\end{array}$ \\
\hline NESA & $\begin{array}{l}\text { Joint Nutrition, Child, and } \\
\text { Food Security Programme }\end{array}$ & NESA & $\begin{array}{l}\text { Nutrition Enfant et Sécurité } \\
\text { Alimentaire }\end{array}$ \\
\hline NETS & $\begin{array}{l}\text { Child Targeted Nutrition } \\
\text { andSocial Transfers }\end{array}$ & NETS & $\begin{array}{l}\text { Nutrition Ciblée sur l'Enfant et } \\
\text { les Transferts Sociaux }\end{array}$ \\
\hline NGO & $\begin{array}{l}\text { Non Governmental } \\
\text { Organization }\end{array}$ & ONG & $\begin{array}{l}\text { Organisation } \\
\text { Non-Gouvernementale }\end{array}$ \\
\hline P2RS & $\begin{array}{l}\text { Multinational Programme } \\
\text { for Food and Nutrition } \\
\text { Resilience Building in the } \\
\text { Sahel }\end{array}$ & P2RS & $\begin{array}{l}\text { Programme Multinational de } \\
\text { Renforcement de la Résilience } \\
\text { à l'Insécurité Alimentaire et } \\
\text { Nutritionnelle au Sahel }\end{array}$ \\
\hline PADPA & $\begin{array}{l}\text { Action Plan for Fishing and } \\
\text { Aquiculture Development }\end{array}$ & PADPA & $\begin{array}{l}\text { Plan d'Action pour le } \\
\text { Développement de la Pêche et } \\
\text { de l'Aquaculture }\end{array}$ \\
\hline PAP & $\begin{array}{l}\text { Programme in Support of } \\
\text { the National Agricultural } \\
\text { Investment Programme }\end{array}$ & PAP & $\begin{array}{l}\text { Programme d'Appui au } \\
\text { Programme National } \\
\text { d'Investissement de } \\
\text { l'Agriculture }\end{array}$ \\
\hline PAQUET-EF & $\begin{array}{l}\text { Equity and Transparency } \\
\text { Quality Improvement } \\
\text { Programme }\end{array}$ & PAQUET-EF & $\begin{array}{l}\text { Programme d'Amélioration de } \\
\text { la Qualité, de l'Équité et de la } \\
\text { Transparence de l'Éducation et } \\
\text { de la Formation }\end{array}$ \\
\hline PASAV & $\begin{array}{l}\text { Food Security Support for } \\
\text { Vulnerable Households } \\
\text { Project }\end{array}$ & PASAV & $\begin{array}{l}\text { Projet d’Appui à la Sécurité } \\
\text { Alimentaire des Ménages } \\
\text { Vulnérables }\end{array}$ \\
\hline PCIME-C & $\begin{array}{l}\text { Community Integrated } \\
\text { Management of Childhood } \\
\text { Illnesses }\end{array}$ & PCIME-C & $\begin{array}{l}\text { Prise en Charge Intégrée } \\
\text { des Maladies de l'Enfant } \\
\text { Communautaire }\end{array}$ \\
\hline
\end{tabular}




\begin{tabular}{|c|c|c|c|}
\hline Acronym & English & Acronyme & Français \\
\hline PECMA & $\begin{array}{l}\text { Management of Acute } \\
\text { Malnutrition }\end{array}$ & PECMA & $\begin{array}{l}\text { Prise en Charge de la } \\
\text { Malnutrition Aigüe }\end{array}$ \\
\hline PINKK & $\begin{array}{l}\text { Integrated Nutrition Project } \\
\text { in Kolda and Kédougou } \\
\text { Regions }\end{array}$ & PINKK & $\begin{array}{l}\text { Projet Intégré de Nutrition } \\
\text { dans les Régions de Kolda et } \\
\text { de Kédougou }\end{array}$ \\
\hline PIUS & $\begin{array}{l}\text { Universal Salt lodization } \\
\text { Project }\end{array}$ & PIUS & $\begin{array}{l}\text { Projet "Iodation Universelle du } \\
\text { Sel" }\end{array}$ \\
\hline РMTCT & $\begin{array}{l}\text { Prevention of mother-to-child } \\
\text { transmission }\end{array}$ & PTME & $\begin{array}{l}\text { Prévention de la transmission } \\
\text { mère-enfant }\end{array}$ \\
\hline PNDA & $\begin{array}{l}\text { National Agricultural } \\
\text { Development Programme }\end{array}$ & PNDA & $\begin{array}{l}\text { Programme National de } \\
\text { Développement Agricole }\end{array}$ \\
\hline PNDN & $\begin{array}{l}\text { National Policy for the } \\
\text { Development of Nutrition }\end{array}$ & PNDN & $\begin{array}{l}\text { Politique Nationale de } \\
\text { Developpement de la Nutrition }\end{array}$ \\
\hline PNSE & Child Survival Strategic Plan & PNSE & $\begin{array}{l}\text { Plan National pour la Survie de } \\
\text { l'Enfant }\end{array}$ \\
\hline PRF & $\begin{array}{l}\text { Programme for the } \\
\text { Enhancement of [Food] } \\
\text { Fortification in Senegal }\end{array}$ & PRF & $\begin{array}{l}\text { Programme de Renforcement } \\
\text { de la Fortification au Sénégal }\end{array}$ \\
\hline PRN & $\begin{array}{l}\text { Nutrition Enhancement } \\
\text { Program }\end{array}$ & PRN & $\begin{array}{l}\text { Programme de Renforcement } \\
\text { de la Nutrition }\end{array}$ \\
\hline PSE & Emerging Senegal Plan & PSE & Plan Sénégal Émergent \\
\hline PSMN & $\begin{array}{l}\text { Multisectoral Strategic } \\
\text { Nutrition Plan }\end{array}$ & PSMN & $\begin{array}{l}\text { Plan Stratégique Multisectoriel } \\
\text { de la Nutrition }\end{array}$ \\
\hline RBF & Results-Based Financing & FBR & $\begin{array}{l}\text { Financement Basé sur les } \\
\text { Résultats }\end{array}$ \\
\hline $\mathrm{REACH}$ & $\begin{array}{l}\text { Renewed Efforts Against } \\
\text { Child Hunger and } \\
\text { Undernutrition }\end{array}$ & REACH & $\begin{array}{l}\text { Efforts Renouvelés Contre la } \\
\text { Faim et la Sous-alimentation }\end{array}$ \\
\hline SAED & $\begin{array}{l}\text { National Authority } \\
\text { for Reclamation and } \\
\text { Development of Land of } \\
\text { the River Basin Delta and } \\
\text { Valleys of Rivers Senegal } \\
\text { and Faleme }\end{array}$ & SAED & $\begin{array}{l}\text { Société Nationale } \\
\text { d'Aménagement et } \\
\text { d'Exploitation des Terres du } \\
\text { Delta du Fleuve Sénégal et des } \\
\text { Vallées des Fleuves Sénégalet } \\
\text { de la Falémé }\end{array}$ \\
\hline SAM & Severe Acute Malnutrition & MAS & Malnutrition Aiguë Sévère \\
\hline SAP & Sectoral Action Plans & PAS & Plan d'Action Sectoriel \\
\hline SDADL & $\begin{array}{l}\text { Departmental Local } \\
\text { Development Support } \\
\text { Service }\end{array}$ & SDADL & $\begin{array}{l}\text { Service Départemental d'Appui } \\
\text { au Développement Local }\end{array}$ \\
\hline SDAS & $\begin{array}{l}\text { Departmental Service for } \\
\text { Social Action }\end{array}$ & SDAS & $\begin{array}{l}\text { Service Départemental de } \\
\text { l'Action Sociale }\end{array}$ \\
\hline SDDR & $\begin{array}{l}\text { Departmental Service for } \\
\text { Rural Development }\end{array}$ & SDDR & $\begin{array}{l}\text { Service Départemental du } \\
\text { Développement Rural }\end{array}$ \\
\hline
\end{tabular}




\begin{tabular}{|c|c|c|c|}
\hline Acronym & English & Acronyme & Français \\
\hline SMART & Standardized Monitoring and & Enquêtes & Enquêtes Suivi et Evaluation \\
\hline Survey & $\begin{array}{l}\text { Assessment of Relief and } \\
\text { Transitions Survey }\end{array}$ & SMART & $\begin{array}{l}\text { Standardisés des Urgences et } \\
\text { Transitions }\end{array}$ \\
\hline SNEIPS & $\begin{array}{l}\text { National Service for } \\
\text { Education and Information } \\
\text { on Health }\end{array}$ & SNEIPS & $\begin{array}{l}\text { Service National de l' Éducation } \\
\text { et de l'Information pour la Santé }\end{array}$ \\
\hline SUN & $\begin{array}{l}\text { Scaling Up Nutrition } \\
\text { Movement }\end{array}$ & SUN & $\begin{array}{l}\text { Mouvement pour le } \\
\text { Renforcement de la Nutrition }\end{array}$ \\
\hline SYSCOA & $\begin{array}{l}\text { West African Accounting } \\
\text { System }\end{array}$ & SYSCOA & $\begin{array}{l}\text { Système Comptable } \\
\text { Ouest-Africain }\end{array}$ \\
\hline TFP & $\begin{array}{l}\text { Technical and Financial } \\
\text { Partner }\end{array}$ & PTF & $\begin{array}{l}\text { Partenaire Technique et } \\
\text { Financier }\end{array}$ \\
\hline UCAD & $\begin{array}{l}\text { Cheikh Anta Diop University } \\
\text { of Dakar }\end{array}$ & UCAD & $\begin{array}{l}\text { Université Cheikh Anta Diop de } \\
\text { Dakar }\end{array}$ \\
\hline UAL & $\begin{array}{l}\text { Administration and Logistics } \\
\text { Unit }\end{array}$ & UAL & $\begin{array}{l}\text { Unité Administration et } \\
\text { Logistiques }\end{array}$ \\
\hline UFC & Financial and Accounts Unit & UFC & Unité Financière et Comptable \\
\hline UNFPA & $\begin{array}{l}\text { United Nations Population } \\
\text { Fund }\end{array}$ & FNUAP & $\begin{array}{l}\text { Fonds des Nations Unies pour } \\
\text { la Population }\end{array}$ \\
\hline UNICEF & $\begin{array}{l}\text { United Nations Children's } \\
\text { Fund }\end{array}$ & UNICEF & $\begin{array}{l}\text { Fonds des Nations Unies pour } \\
\text { I'Enfance }\end{array}$ \\
\hline UPA & Agricultural Policy Unit & UPA & Unité de Politique Agricole \\
\hline UPS & Policy and Strategy Unit & UPS & Unité Politique et Stratégie \\
\hline UREN & $\begin{array}{l}\text { Recovery and Nutritional } \\
\text { Education Unit }\end{array}$ & UREN & $\begin{array}{l}\text { Unité de Réhabilitation et d' } \\
\text { Éducation Nutritionnelle }\end{array}$ \\
\hline USAID & $\begin{array}{l}\text { United States Agency for } \\
\text { International Development }\end{array}$ & USAID & $\begin{array}{l}\text { Agence des États-Unis pour le } \\
\text { Développement International }\end{array}$ \\
\hline USDA & $\begin{array}{l}\text { United States Department of } \\
\text { Agriculture }\end{array}$ & USDA & $\begin{array}{l}\text { Ministère de l'Agriculture des } \\
\text { États-Unis }\end{array}$ \\
\hline USO & $\begin{array}{l}\text { Operations Monitoring and } \\
\text { Support Unit }\end{array}$ & USO & $\begin{array}{l}\text { Unité de Suivi et Appui aux } \\
\text { Opérations }\end{array}$ \\
\hline WAEMU & WAEMU) & UEMOA & $\begin{array}{l}\text { Union Économique et } \\
\text { Monétaire Ouest-Africaine }\end{array}$ \\
\hline WFP & World Food Programme & PAM & Programme Alimentaire Mondial \\
\hline WHA & World Health Assembly & AMS & $\begin{array}{l}\text { Assemblée Mondiale de la } \\
\text { Santé }\end{array}$ \\
\hline WHO & World Health Organization & OMS & $\begin{array}{l}\text { Organisation Mondiale de la } \\
\text { Santé }\end{array}$ \\
\hline WVI & World Vision International & WVI & Vision du Monde \\
\hline
\end{tabular}




\section{Contents}

Acknowledgments iii

Executive Summary 1

$\begin{array}{ll}\text { Introduction } & 7\end{array}$

Institutional Environment of the Nutrition Sector 11

$\begin{array}{ll}\text { Stakeholders of the Nutrition Sector } & 17\end{array}$

Stakeholder Contributions to Improving Nutrition 23

Organizational Capacities of the Nutrition Sector $\quad 27$

Organizational Culture and Incentives within the Units of Analysis 41

Organizational Performance of the Units of Analysis 45

Strengths and Obstacles $\quad 55$

Guidelines for Strengthening Institutional and Organizational Capacity within Senegal's Nutrition Sector 59

List of Recommendations by Chapter $\quad 71$

Interview and Focus Group Participants $\quad 75$

$\begin{array}{ll}\text { Endnotes } & 85\end{array}$

$\begin{array}{ll}\text { References } & 87\end{array}$

List of Boxes

Box 1: Nutrition-Related Policies in Senegal Since 2000

List of Figures

Figure 1: Survey Results for "Which Institution is Driving Progress in Nutrition?" 14

Figure 2: Funding Provided by Public Sector Nutrition Stakeholders for the Implementation $\begin{array}{ll}\text { of Nutrition-Specific Interventions } & 25\end{array}$

Figure 3: Breakdown of BEN Staff by Training Area 30

Figure 4: BEN Planning Process 34

Figure 5: $\quad$ CLM Values $\quad 42$

Figure 6: Comparative Organizational Performance between Units of Analysis 46

Figure 7: $\quad$ BEN-CLM Results for Selected Indicators, 2009-14 48

Figure 8: Responses to IOCA Survey Question on Effectiveness 49

Figure 9: Breakdown of BEN Budget Expenses 50 
Figure 10: Nutrition Stakeholder Responses to: "What Is Your Overall Level of Satisfaction with the CLM Mission?"

Figure 11: CLM Financial Resources 2004-15

Figure 12: CLM Funding Sources 2004 to 2015

Figure 13: Donors' Financial Support of the BEN 2004-2015

\section{List of Tables}

Table 1: Quantitative Indicator Scores for IOCA Tool

Table 2: $\quad$ Ratings Assigned to IOCA Domain Scores

(based on Quantitative Indicator Averages) 9

Table 3: Nutrition Sector Stakeholders $\quad 18$

Table 4: Projects and programs implemented under the authority of the BEN 20

Table 5: Key Interventions and Coverage of Target Groups at the National Level 24

Table 6: BEN Monitoring System within the PRN Framework

Table 7: Access to Technology and Infrastructure-BEN, BER (Thiès), DAPSA, DAN, and DCMS

Table 8: Assessment of Attainment of Mission: CLM and BEN 47

Table 9: Costed Institutional and Organizational Capacity-Building Plan 64 


\section{Executive Summary}

T he government of Senegal has adopted a new nutrition policy, the Document de Politique National de Développement de la Nutrition (National Policy for the Development of Nutrition) (PNDN) ${ }^{1}$ for the period 2015 to 2025, which it intends to operationalize through a multisectoral nutrition strategy, the Plan Stratégique Multisectoriel de la Nutrition (Multisectoral Nutrition Strategic Plan) (PSMN).

To strengthen this multisectoral approach, which aims to sustainably broaden the coverage and improve the quality of nutrition services, the government joined the Scaling Up Nutrition (SUN) Movement in 2011, and adopted the United Nations approach for Renewed Efforts Against Child Hunger and Undernutrition (REACH) in 2014. These initiatives are intended to strengthen institutional capacity and facilitate a multisectoral process whereby governments plan, prioritize, and more efficiently manage nutrition actions involving multiple stakeholders.

Against this background, the World Bank-REACHUnited Nations Children's Fund (UNICEF) Partnership undertook to support the government of Senegal in conducting a diagnostic study to assess the organizational and institutional capacities of the nutrition sector to better appraise its performance, and to make recommendations for strengthening the organizational and institutional architecture in support of the PNDN and the PSMN.

\section{Study Objective and Subjects}

The objective of the study and this subsequent report is twofold: First, to improve understanding of the organizational and institutional capacities and constraints of Senegal's nutrition sector, and second, to identify what capacities are required to enhance future functionality, especially with respect to multisectoral coordination. The study assumed that sector performance is influenced by (1) a set of changing rules ingrained in the context within which the sector operates; (2) organizational capacity; and (3) the organizational capacities and motivation of nutrition actors at central, regional, and local levels. Based on these assumptions, the study diagnosed the human and functional capacities of:

- The Cellule de Lutte contre la Malnutrition (Nutrition Coordination Unit) (CLM); and

- The Bureau Exécutif National (National Executive Bureau) (BEN); 
as well as the following ministerial entities:

- The Division de l'Alimentation et de la Nutrition (Division of Food and Nutrition) (DAN) within the Ministère de la Santé et de l'Action Sociale (Ministry of Health and Social Action) (MSAS);

- The Direction de l'Analyse et de la Prévision des Statistiques Agricoles (Agricultural Statistics Analysis and Forecasting Department) (DAPSA) within the Ministère de l'Agriculture et de l'Équipement (Rural Ministry of Agriculture and Rural Infrastructure) (MAER);

- The Division du Contrôle Médical Scolaire (School Health Checks Division) (DCMS) of the Ministère de l'Éducation (Ministry of Education) (MEN); and

- The Ministère de l'Élevage et des Productions Animales (Ministry of Livestock and Animal Husbandry) (MEPA).

The six agencies are referred to as "units of analysis" throughout the report.

Although important, the institutional analysis did not include the Ministry of Mines, Energy and Hydraulics or the Social Development and National Solidarity Ministry. Rather, these ministries' contribution to the study was made through their participation in interviews that enriched the analysis of the nutrition sector.

\section{Methodological Approach}

An institutional and organizational assessment tool was administered to gather data on institutional and organizational life. Facilitation guides were used for the key informant interviews and key stakeholder focus group discussions in Dakar, in the regions, and with beneficiary local governments and communities. Interviews were conducted at the national level with members of the public sector (45), technical and financial partners (TFPs) (17), the research sector (4) and international non governmental organizations (INGOs) (4). Two focus groups were organized with national NGOs (4 participants) and the private sector (4 participants). In the Tambacounda, Fatick, and Thiès regions, individual or group interviews were conducted with 5 administrative authorities (governors and prefects), 26 decentralized services, 4 collectivités locales (local government collectives) ${ }^{2}$ (CLs)/NGOs; and 4 Agences d'Exécution Communautaire (Community Executing Agencies) (AECs). At the community level, 9 focus groups were held with a total of over 80 participants. Finally, an online questionnaire was sent to 143 people identified for their contribution to nutrition at the national, regional or departmental level. These surveyed individuals were from various sectors: public, private, research, TFPs, INGOs, and national NGOs. The response rate was 44 percent.

\section{Findings}

The assessment found that Senegal's nutrition sector has important assets that can improve the sector's performance by making it more effective and efficient. These advantages include the existence of the CLM and its anchoring to the Prime Minister's office, well-articulated nutrition policies and programs, funding from the government and its partners, Senegal's participation in the SUN Movement and the REACH initiative, institutionalization of the multisectoral approach, and existence of an academic nutrition curriculum.

\section{Institutional environment}

In general, Senegal's nutrition sector has experienced a positive evolution and a favorable political environment. Several policies have been developed by the government to institutionalize nutrition and to align with global initiatives.

Nutrition's political "anchor" is the CLM and the BEN, which are attached to the Prime Minister's office. Over 77 percent of the 63 members of the nutrition sector who responded to the online survey recognize the lead role played by the CLM in making nutrition a national priority. Although this role positions the CLM as symbolically central to the implementation of a multisectoral approach, the context has changed significantly since the creation of the CLM and the BEN. 
Today, the sector needs additional strong leadership to increase coordination and collaboration between sector stakeholders.

With respect to financing, the nutrition sector operates within a fragile domestic economic environment marked by weak growth. As such, investment in nutrition faces strong competition for resources. The CLM's budget is included under the investment budget, and its allocations are dependent on political will. The CLM should actively work to secure continued political commitment to increase its budget allocations and the government's investment in nutrition. For example, the harmonized public finance framework of the Union Économique et Monétaire Ouest-Africaine (West African Economic and Monetary Union) (WAEMU) provides opportunities for the nutrition sector to lobby for increased funds by using results-based management and by calling for greater accountability of ministers for the authorization of expenses incurred by their ministries.

\section{Performance of the units of analysis}

The institutions assessed in this study are referred to throughout this report as "units of analysis". Results of the assessment for the different units are based on four areas of performance: efficiency, effectiveness, relevance, and financial viability. The overall score was average, with efficiency obtaining the highest (70 percent) and financial viability the lowest (57 percent) scores.

Analysis of the respective missions of the CLM and BEN reveals a fundamental question of responsibility for the implementation of CLM's mission. With the evolution of time and experience, there is a need to broaden the mission of BEN to align with current practice.

The nutrition sector and CLM must adapt to the changing context to remain relevant. Multisectorality, collaboration, and coordination of actors within the sector, the institutionalization of nutrition by key ministries as reflected in the provision of appropriate budgetary allocations, strengthening human resources in nutrition, the integration of objectives and alignment of policies provide new critical avenues for the governance of the sector.

The units of analysis diversified their funding sources by developing multiple partnerships. However, despite government efforts, the financial viability of the nutrition sector is impaired by its dependence on external funding.

The shortage of human resources specializing in nutrition is a problem that affects units of analysis at all levels. Incentives (financial and nonfinancial compensation and employee morale, for example) are appreciated by different units of analysis to varying degrees. On the whole, each entity needs to find innovative methods to motivate their personnel and boost their morale at the central and decentralized levels.

\section{Major Challenges to the Nutrition Sector}

The study identified the following challenges to the nutrition sector: institutionalization of nutrition by sectoral ministries; strengthening the coordination of sector stakeholders and TFPs; strengthening CLM leadership; reduction of dependence on external funding; shortage of human resources; and strengthening of training and research in the field of nutrition.

For government services in general, human resources are more numerous at the central level and become fewer as one descends toward the regions, departments, and subprefectures. However, the shortage of human resources specializing in nutrition is a problem that affects all units of analysis at both central and decentralized levels.

Financial management of the BEN is based on clear protocols defined in procedure manuals, process manuals, management manuals, and guides. In other words, BEN has transparent financial management, and mechanisms are in place to minimize risks and maximize the protection of resources. BEN is also audited regularly. In contrast, sectoral entities such as DAN, DCMS, and DAPSA, do not have financial 
management autonomy. Despite being assigned to distinct missions within their respective ministries, budget allocations for these institutions are attached to those of their line supervisors. Furthermore, most of the government's budget allocations go to operations.

Communication and collaboration between the units of analysis and other nutrition-relevant actors pose challenges to the development and performance of the sector. While sector stakeholders reported strong collaboration in the development of policies and strategies, planning, information exchange, and the sharing of results, study participants had mixed opinions about communication and technical collaboration, and believed that collaboration is weak in areas of monitoring and evaluation, and financial resources.

The study showed that TFPs play a key role in Senegal's nutrition sector, with one of the biggest challenges being coordination of TFPs and harmonization of interventions and strategies in the ultimate interest of the country. The nutrition sector needs pooled financing guided by shared priorities. With the development of the PSMN, it has become increasingly imperative for TFPs to step up their collaboration.

\section{Strategic Guidelines for Institutional and Organizational Capacity Building of the Nutrition Sector}

To improve its performance, the nutrition sector must strengthen its institutional and organizational capacities by addressing challenges related to the environment, motivation, and organizational capacity. Strategic guidelines for achieving these goals are presented below. They are organized into three components: governance; resources; and training and research.

\section{Component 1: Governance}

- Strengthen CLM leadership so that it can carry out its mission in an optimal fashion.

Nutrition sector stakeholders believe it is high time to refocus the CLM's mission. Until now, the CLM has focused on validation of the Plan d'Action du Budget Annuel (Annual Budget Action Plan) (ABAP) and the Rapport de Suivi Financier (Financial Progress Report) (FPR) prepared by BEN within the framework of the Programme de Renforcement de la Nutrition (Nutrition Enhancement Program) (PRN) and other national programs and projects, leaving little scope for its strategic mission to coordinate the sector overall. To strengthen CLM capacity, two strategies are proposed: First, adapt the CLM's internal operations to the sector's new needs; and second, better align BEN's mission with that of the CLM.

- Ensure multisectoral coordination within the nutrition sector.

Multisectoral coordination is critical for optimizing the nutrition sensitivity of relevant sectors and for ensuring consistency of nutrition interventions at different levels of government. The issue of sector coordination is intimately linked to the leadership of the CLM, with the CLM taking a lead role in facilitating collaboration and coordination.

- Develop institutional communication strategies. Strengthening institutional communication is vital for optimal development of Senegal's nutrition sector. The units of analysis should develop and implement communication plans. The CLM's objectives should include securing the commitment of sector leaders and politicians, as well as improving communication with TFPs.

- Ensure strategic multisectoral and operational planning.

A major challenge to implementation of a multisectoral approach is ensuring participation and ownership of relevant sectors in strategic and operational planning. As such, Sectoral Action Plans (SAPs) are under development through the CLM as part of the PSMN. SAPs support institutionalization of nutrition within a given sector through budget allocations and the clarification of roles and responsibilities. The CLM can facilitate sectoral implementation of the PSMN by aligning the PSMN preparation period with sectoral Documents de Programmation Pluriannuelle des Dépenses (Multiannual Expenditure Planning Documents) (DPPD). In the short term each sector will need to ensure: 
(1) that appropriate budget allocations are provided for implementation of the SAP; (2) monitoring of expenditures; and (3) evaluation of their impact.

- Establish a common results framework and an information and knowledge management system.

Through the PSMN, a common results framework integrating required levels of accountability should be defined. It is essential that the CLM, together with sector stakeholders, establishes rigorous monitoring and evaluation mechanisms to ensure the quality, reliability, validity, and timeliness of data at all levels, and to organize joint follow-up meetings and sectoral reviews. The common results framework should be formulated at regional, departmental, and community levels. Equally critical is a nutrition information and knowledge management system, which is essential for decision making, and to improve and capitalize on the nutrition knowledge accumulated over time.

\section{Component 2: Resources}

- Develop strategies for establishing a systemof nutrition financing and financial resource mobilization. A financing system for the nutrition sector is urgently needed. The scaling up of the PRN, for example, is facing financial-among other-resource shortages. Most sectors are expecting resources from the CLM for management of nutrition interventions. As such, the CLM must increase its strategies for resource mobilization as follows: First, it should finalize its project investment document (the financing plan of the PSMN). Second, it should work closely with the sectors-and particularly the Ministère de l'Économie, des Finances et du Plan (Ministry of Finance, the Economy and Planning) (MEFP) - to create budget lines dedicated to nutrition, pronutrition interventions in sectoral budgets, and interventions of the PSMN financed within the sectors' own budgets. Third, it should develop and implement resource mobilization strategies based on strategic documents and the PSMN financing plan. These strategies should advocate for (1) an increase in the nutrition budget line to scale-up the BEN-managed PRN; (2) greater accountability of the sectors through budget appropriation; and (3) organization of a donor meeting. To support these efforts, the BEN of the CLM-or with the proposed alignment of the BEN and CLM missions, the BEN-should develop expertise in resource mobilization. Within the framework of decentralization, BEN should continue to work with the CLs to increase their contributions to nutrition financing.

\section{- Strengthen human resources and incentives}

The nutrition sector faces a challenge of insufficient human resources. Results from this study indicate the problem is exacerbated by an organizational structure that concentrates nutrition personnel at the central level. We recommend that the government increase staff in key state institutions and address the lack of motivation by improving salaries and benefits. BEN should strengthen its staff by filling both vacancies and new positions based on its revised organizational structure. It should also look for other ways of boosting staff motivation. Additionally, the CLM should develop a national strategy for recruiting nutrition personnel based on a study conducted with the specific purpose of assessing training, number, and positions of nutrition specialists at the national level.

- Improve the technological and logistic capacity and infrastructure of the units of analysis.

Units must find innovative ways of making optimal use of communication technology to improve organizational performance. There is a difficult problem with workspace that warrants special attention and effort to find adequate and lasting solutions. Finally, units should clarify logistical resource needs at central and regional levels, and develop strategies for their acquisition.

\section{Component 3: Training and education}

- Make strategic investments in training and education. Weak nutrition capacity is a pressing issue at all levels. Three types of training and education are recommended: (1) building nutrition capacity of stakeholders at all levels; (2) academic and professional training in nutrition; and (3) continuous training for nutiriton professionals as well as a stronger focus on research. 
Costed Institutional and Organizational Capacity-building Plan

The need to build capacity that enables CLM member sectors, through their focal points, to work together to mainstream nutrition is the base on which this cost- ed plan was developed. It covers the BEN and its BERs, as well as line ministries designated by the CLM for improved governance of the nutrition sector. Functional aspects of leadership, coordination, management, and monitoring and assessment are each addressed. 


\section{Context of the Study}

In Senegal, government commitment to nutrition has increased progressively in recent decades. The creation in 2001 of the Cellule de Lutte Contre la Malnutrition (the Nutrition Coordination

Unit) (CLM) and its Bureau Exécutif National (the National Executive Bureau) (BEN) marked a major turning point, as did an increase in annual budget allocations to nutrition (from US $\$ 0.3$ million in 2002 to US $\$ 5.7$ million in 2015) and concomitant intensification of community-based nutrition interventions. This commitment is reflected in the improvement of nutrition indicators. With a 46 percent reduction in under-five stunting, from 34.4 percent in 1992 to 19.4 percent in 2014 , Senegal has witnessed one of the biggest rates of improvement in the fight against undernutrition in the world and currently has one of the lowest rates of stunting in Sub-Saharan Africa (Spray 2018).

However, these developments have not led to greater visibility of pronutrition interventions in relevant sectors such as agriculture, livestock, health, education, social protection, and hydraulics. Moreover, some nutrition-specific problems with major conse-

\section{Introduction}

quences-low birthweight, iron-deficiency anemia, adolescent nutrition, and maternal undernutrition-still receive little attention. These shortcomings threaten the gains achieved in recent decades.

Recognizing the challenge, the government of Senegal joined the SUN Movement in 2011 and adopted the United Nations REACH approach in 2014. Both initiatives aim to strengthen institutional capacity and facilitate a multisectoral process to help governments plan, prioritize and more efficiently manage nutrition actions involving multiple stakeholders. With respect to national policy, the Document de Politique National de Développement de la Nutrition (National Policy for the Development of Nutrition) (PNDN) has been adopted for the period 2015 to 2025 . The PNDN will be operationalized through a multisectoral nutrition strategy, the Plan Stratégique Multisectoriel de la Nutrition (Multisectoral Nutrition Strategic Plan) (PSMN). The PSMN is designed as a sectoral reform program to broaden coverage and improve the quality of nutrition services.

Against this background, this institutional and organizational capacity assessment (IOCA) analyzes the performance of Senegal's nutrition sector and makes 
recommendations for strengthening implementation of the PNDN and forthcoming PSMN.

\section{Focus of the Study}

The assessment was based on the premise that Senegal's nutrition sector is shaped (1) by a set of changing rules ingrained in the context within which the sector operates, and (2) by the organizational capacities and motivations of nutrition actors at central, regional, and local levels. As such, the following topics were used as study foci and for framing this report:

- The institutional environment

- Stakeholders of the nutrition sector and institutional and organizational units of analysis

- Contributions of stakeholders in the nutrition sector to improving the nutritional status of children under five, women of child-bearing age, and adolescent girls

- Opportunities and key issues relating to the organizational capacities that affect performance

- Opportunities and key issues relating to the organizational motivations that affect performance

- Analysis of the performance of the units of analysis

- Major strengths and weaknesses of the nutrition sector

- Strategic guidance for strengthening the institutional and organizational capacities of the nutrition sector

- The costed capacity-building plan

\section{Methodological Approach}

\section{Literature review}

Drafting the report provided an opportunity to review the large body of work on nutrition. Articles, reports, and books were consulted to increase understanding of the global, political, economic, sociocultural, administrative, and legislative environments in which the Senegalese nutrition sector operates. In addition, legislative texts, activity and financial reports, proce- dural manuals, and internal documents from the CLM, BEN, MEPA, DCMS, DAPSA and DAN were consulted, as were documents from AECs, TFPs, and NGOs. Documents were collected online and from study participants, with variations in availability depending on which units of analysis and themes were being assessed.

\section{Selection of units of analysis}

Given the range and number of nutrition stakeholders in Senegal, including NGOs, private companies, civil society organizations, and public sector entities, an in-depth analysis that was also fully comprehensive was not possible. Given this limitation, and because improved coordination of actions by government is fundamental to fostering ownership and sustainability of the nutrition sector, this study focuses exclusively on (1) the CLM, BEN, and the Bureau Exécutif Régional (Regional Executive Bureau) (BER) of Thiès as the government agents responsible for coordinating nutrition sector stakeholders, and (2) key administrative entities of ministries in charge of the PNDN, namely the DAN, DAPSA of the MAER, DCMS of the MEN and the MEPA. The Ministry of Mines, Energy and Hydraulics, the Social Development and National Solidarity Ministry, and the Fisheries and Maritime Economy Ministry were not included as units of analysis. Representatives from these ministries did however contribute to the richness of study findings through interviews that complement the institutional analysis.

\section{Selection of regions}

The selection of regions was proposed by the BEN and was based on knowledge of the context, proximity to Dakar, and the following criteria:

- Implementation of an integrated nutrition program, such as the Projet d'Appui à la Sécurité Alimentaire (Food Security Support for Vulnerable Households Project) (PASAV)

- Indicators of acute or high chronic malnutrition

- Existence of communities having benefited from an integrated nutrition intervention package 
The regions of Tambacounda and Fatick were selected because they best fit the criteria. Thiès was selected for an institutional and organizational analysis of its BER and interviews with its decentralized sectoral services.

\section{Data gathering tools and strategies}

To ensure that data gathering was systematized, the following tools were developed:

Institutional and organizational capacities

assessment (IOCA) tool:

The study was conducted using a tool designed to assess four fundamental domains of institutional and organizational capacity: ${ }^{3}$

1. Institutional environment (the legislative, political, economic and sociocultural factors that influence how an organization functions)

2. Organizational capacities (resources, program management, process management, and intersectoral collaboration)

3. Organizational motivation (organizational culture and incentives)

4. Organizational performance (effectiveness, efficiency, relevance, and financial viability)

Each domain was assessed using multiple criteria, with each criterion assigned a set of indicators. Each indicator received a quantitative score between 0 and 5 (table 1) as well as a qualitative component.

Based on these individual indicator scores, each of the four domains received an average score (calculated by averaging the scores of the indicators in a given domain). Expressed as a percentage, these scores are rated "Strong", "Average", or "Poor" (table 2). In addition to assessing overall organizational and institutional capacity, these scores were also used to compare capacity across domains.

Administered in a participatory and dynamic manner, the IOCA tool was used to collect data on the institutional and organizational life of the CLM, BEN, key ministerial entities (MEPA, DAPSA, DAN, and DCMS) and the Thiès BER.

TABLE 1: Quantitative Indicator Scores for IOCA Tool

\begin{tabular}{cl} 
Score & Assessment \\
\hline 5 & Very good/extremely strong/always \\
4 & Good/strong/generally \\
3 & Average/fairly strong/sometimes \\
2 & Weak/not strong/seldom \\
1 & Very weak/not at all/never \\
\hline
\end{tabular}

TABLE 2: Ratings Assigned to IOCA Domain Scores (based on Quantitative Indicator Averages)

\begin{tabular}{cc} 
Score & $\begin{array}{c}\text { Institutional and } \\
\text { organizational capacity }\end{array}$ \\
\hline 75 percent or more & Strong \\
\hline 50 percent to 74 percent & Average \\
\hline Less than 50 percent & Poor \\
\hline
\end{tabular}

Interview guides:

Guides for individual interviews, focus group discussions, and a stakeholder survey questionnaire were developed to assess stakeholder satisfaction and perceptions of CLM performance, collaboration, and nutrition sector needs.

\section{Definition of concepts}

For the purposes of this study and report, including all interview guides, organizational performance was defined as the capacity of an organization to achieve its goals and fulfill its overall mission.

\section{Administration of the IOCA tool, interviews, and focus groups}

Data were gathered from several stakeholders in the nutrition sector and at various levels from May 23 to June 29, 2016.

Field visits were undertaken to administer the IOCA tool at the CLM, BEN, the BER of Thiès, and at key 
ministerial entities of the nutrition sector. Additionally, in-depth individual interviews were conducted with key informants from government, local and international NGOs, TFPs, and other stakeholders with sound knowledge of the nutrition sector. At the national level, interviews were conducted with over 70 stakeholders representing the public sector (45), TFPs (17), the research sector (4) and INGOs (4). Two focus groups were organized with national NGOs (4 participants) and the private sector (4 participants). A total of 39 individual or group interviews were conducted with 5 administrative authorities (governors and prefects), 26 staff from decentralized services, 4 CLs, and 4 members of NGOs. Nine community focus groups were held with over 80 participants, and 4 focus groups were held with AECs. Finally, an online questionnaire was sent to 143 individuals in the nutrition sector identified for their contributions at national, regional or departmental level and in various sectors (public, private, research, TFP, INGO, and national NGO). The response rate for this survey was 44 percent.

\section{Data analysis, validation of results and report writing}

Literature review results, information on existing projects obtained from the BEN, findings from the IOCA tool, individual interviews, focus groups, and online surveys were organized by theme using thematic matrices that showed similarities and differences across data type. This method permitted prioritization of themes according to the importance attached to them by stakeholders. It also permitted triangulation of the data, strengthening the quality and robustness of conclusions concerning organizational performance of entities with respect to effectiveness, efficiency, relevance, and financial viability.

Validation of assessment results-first by the CLM, BEN, and ministerial entities-enabled integration of observations made by various stakeholders. Additionally, several independent reviews of the report were made, and the observations and recommendations collected during these reviews enriched the data analysis and helped to finalize the report.

\section{Methodological limits}

A few shortcomings noted during the data gathering exercise need to be mentioned. The unavailability of certain personnel in key ministries was a major problem, forcing us to modify aspects of the methodology and the work schedule. In some cases, requirements for the administration of the IOCA tool could not be met because of these constraints. Additionally, some important meetings with members of the CLM and DAPSA teams did not take place, compromising data collection. Finally, access to the document repositories of the various units of analysis was uneven, reducing opportunities for comparisons across units. 


\section{Institutional Environment of the Nutrition Sector}

\section{KEY POINTS}

- Social, cultural, religious, and demographic factors affect nutrition in Senegal.

- Senegal's economy remains vulnerable to both internal and external shocks and the country's growth has been below 5 percent for the past several years.

- Given the fragile economic environment, nutrition investment is faced with strong competition for resources.

- The nutrition sector in Senegal has developed positively thanks to an enabling political environment.

- The Senegalese government has developed several policies and initiatives to institutionalize nutrition.
- State commitment is also shown through government participation in global movements, including alignment of the policies mentioned above with global nutrition goals.

- WAEMU directives and its new, harmonized public finance framework provide opportunities to use results-based management for greater ministerial accountability in the authorization of nutritionrelated expenditures.

- Institutionally, nutrition is thoroughly grounded through the creation of the CLM and BEN, and their attachment to the Prime Minister's Office; over 77 percent of nutrition sector actors see these agencies as playing lead roles in the sector.
In this section we analyze the influence of the institutional environment on the nutrition sector. Four points are discussed:

- Sociocultural and demographic factors

- Economic factors

- Nutrition policy

- Institutional anchoring of nutrition

\section{Sociocultural and Demographic Factors}

Sociocultural values are deeply rooted in Senegal, including beliefs and customs that adversely affect the adoption of nutrition-promoting behaviors. These include the low social status of women and their limited decision-making power-in certain regions, women living with their families-in-law have 
no decision-making power-and food taboos and prohibitions.

Additionally, many women engage in income-generating activities, which, in most cases, oblige them to leave the care of their children to grandmothers or other family members, making it difficult to practice exclusive breastfeeding (EBF).

The illiteracy rate in Senegal is 54.6 percent and is unevenly distributed according to gender, age, and place of residence. The majority of illiterates are women (59 percent) and people living in rural areas (62.7 percent) (ANSD 2014).

Poverty, social inequality, and geographic disparities remain major concerns. Although poverty declined drastically between 2005 and 2011, progress is currently stalled. Poverty is highest in rural areas, and there is marked regional disparity. Not surprisingly, poor households have the highest rates of chronic malnutrition and lowest use of health services.

\section{Economic Factors}

Due to deceleration of traditional drivers and lack of new growth and export levers, national economic growth in Senegal has declined. Currently, Senegal lags behind the growth momentum experienced across the West African subregion and attracts few investors in strategic sectors and infrastructure.

Under the Plan Sénégal Émergent (Emerging Senegal Plan) (PSE), Senegal aims to reverse these trends and to achieve emerging economy status by 2035 . Using a new development model set out by the PSE, Senegal seeks to develop a reference framework of economic and social policy to reduce vulnerability to shocks (such as severe weather events, fluctuating oil prices, food price shocks, and declines in migrant remittances).

The PSE creates both opportunities and challenges for nutrition in terms of budget allocation. There is fierce competition for the state's financial resources and the PSE positions nutrition in competition with other key priorities of the government. Depending on the capacity of the sector, this positioning could lead government to make strategic choices that are either detrimental or beneficial to nutrition funding.

In the international economic environment for nutrition, donors have pledged to contribute US\$19.68 billion dollars by 2020 within the framework of the Global Nutrition for Growth Compact (N4G). As of 2016, 61 percent of these commitments had been met (IFPRI 2016). Moreover, with the exception of the largest donors (the World Bank and the United States), eight others (Germany, Australia, the European Union, Ireland, the Netherlands, the Bill and Melinda Gates Foundation, the United Kingdom and the Children's Investment Fund Foundation) met 33 percent of their financial commitments under the N4G within two years, well ahead of the eight-year target (IFPRI 2016). In addition to N4G, appeals for funding for nutrition-specific and nutrition-sensitive programs characterize the international funding environment. Despite these advances, competition for resources remains fierce. Financing depends on the receiving countries' unique economic situations as well as global economic trends.

\section{Nutrition Policy}

A wide range of policies and initiatives have been launched in Senegal to improve nutrition and increase its standing on the political agenda. According to Spray (2018), this evolution can be divided into the following distinct "generations": (1): building the foundation (1950-70); (2) curative approach (1970-90); (3) institutionalization of nutrition (1990-2000); (4) intensification and decentralization (2000-10); and (5) multisectoral convergence (2010 to date).

Box 1 provides a list of the policies and nutrition-related influences that have been enacted during the two most recent generations, during which nutrition has benefited from substantial political commitment. Es- 
pecially indicative of the institutionalization of nutrition within the national dialogue are the 2001 Nutrition Development Policy Letter (LPDN), the establishment of the CLM and BEN and concomitant anchoring of these agencies to the Prime Minister's office (also in 2001), the 2015 National Nutrition Development Policy Document (PNDN), and the 2017 Multi-Sectoral Strategic Plan (PSMN). Political commitment is also reflected in the mainstreaming of nutrition in health and education sector policy documents, in local development plans, and in national development documents (the Poverty Reduction Strategy Paper (DSRP) and the PSE), which serve as the documents of reference that set the country's priorities.

Currently, the PNDN defines the four pillars of country guidance on nutrition: (1) production of food with high nutritive value; (2) processing, distribution, and tarification; (3) education, hygiene, and sanitation; and (4) essential nutrition and health services. The document is in line with the principles of the global nutrition community, as defined by the SUN Movement, N4G, the global nutrition targets of the World Health Assembly (WHA), the Global Nutrition Report, the World Food Summit Action Plan, and the Rome Declaration on World Food Security. On the national level, the PNDN is aligned with the PSE, and with other sectoral documents of reference.

Although, as described above, Senegal's national political environment is favorable toward nutrition, the topic is not part of the discourse of leaders, and politicians do not seem to understand many of its visible and concrete repercussions. As a result, multisectoral convergence remains a challenge, with efforts to institutionalize nutrition at the sectoral level constrained by the will of the concerned sector's leadership. In this context, the harmonized public finance framework

BOX 1: Nutrition-Related Policies in Senegal Since 2000

\section{0 to 2010: Intensification and decentralization}

- Poverty Reduction Strategy Paper (DSRP, 2000)

- Decree mandating universal salt iodization (2000)

- Nutrition Development Policy Letter (LPDN, 2001)

- Decree 2001-770 and Decision on the Establishment of CLM and BEN (2001)

- Nutrition Standards and Protocols (2001)

- PCIME-C Strategic Plan 2002-07 (2002)

- Nutrition Development Policy Letter (LPDN, revised in 2006)

- National Policy on Infant and Young Child Feeding (IYCF, 2006)

- Establishment of the Senegalese Committee for Food Fortification (COSFAM, 2006)

- Child Survival Strategic Plan (PNSE, 2007)

- Strategic Plan of the Nutrition Enhancement Programme (PRN, 2007)

- Decree making it mandatory to fortify oil with vitamin $A$ and wheat flour with iron and folic acid (2009)

Source: Spray 2018.

\section{0 to date: Multisectoral convergence}

- Senegal joins the SUN Movement (2011)

- National Management of Acute Malnutrition protocol (2013)

- Emerging Senegal Plan (PSE, 2014)

- National Policy on Infant and Young Child Feeding (IYCF, 2014)

- National Nutrition Development Policy Document (PNDN, 2015)

- Senegal becomes a member of the SUN Executive Committee (2015)

- Multi-Sectoral Strategic Plan (PSMN, 2017)

- Nutrition Investment Case (Ruel-Bergeron 2018) 
of the West African Economic and Monetary Union (WAEMU) provides opportunities for results-based management and subsequent increased accountability of ministers to nutrition for authorization of expenditures linked to their ministries.

\section{Institutional Anchoring of Nutrition}

Currently, nutrition activities in Senegal are supported by a legislative framework that mandates a strong institutional anchor. The linchpin of this framework is Presidential Decree C No. 2001-770. Enacted in 2001, this Decree replaced the National Committee for the Fight Against Malnutrition with the CLM and placed the agency under the authority of the Prime Minister. Article 2 of this Decree defines the eight missions of the CLM, analyzed below.
A second decree, issued soon thereafter, mandates the BEN as the permanent executive office in charge of day-to-day management and implementation of nutrition programming, primarily the PRN. Currently, multisectoral coordination is not reflected in BEN's mandate. As a result, multisectoral collaboration efforts have been relegated to the sidelines at national, regional, departmental, and local levels. It is imperative to reverse this situation by extending BEN's mandate beyond implementation of the PRN.

The CLM is widely regarded as both innovative and a reflection of Senegal's awareness of the importance of nutrition policy and its consequences for human development. Its membership, defined by Article 3 of the Decree, reflects the multisector impetus envisaged by government, comprising 16 members from the Prime Minister's Office, sectoral ministries, civil society, and CLs.

FIGURE 1: Survey Results for "Which Institution is Driving Progress in Nutrition?"

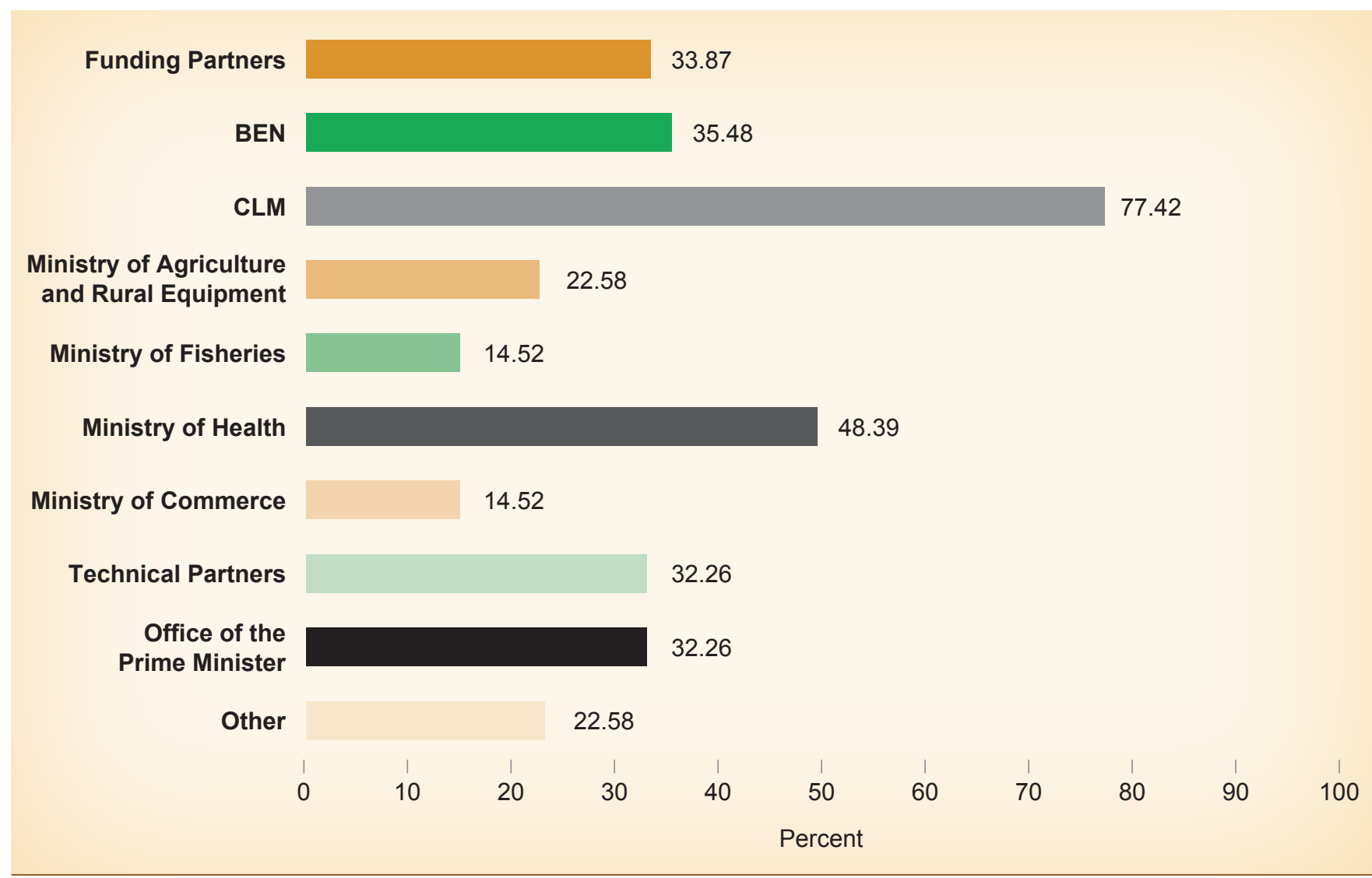

Source: Online surveys of the nutrition sector, June-July 2016. 
The importance of the CLM's role is well-recognized. Results of the online survey conducted for this report indicate that over 77 percent of respondents consider the agency to be the primary "engine" driving progress in nutrition (figure 1).
The CLM has established its reputation after 15 years of existence and continues to earn the trust of successive governments. It has also secured the confidence of donors, initially the World Bank, and several others today.

\section{RECOMMENDATIONS:}

- Enhance the visibility of nutrition in the political discourse. Despite the government's efforts, nutrition is not part of the discourse of leaders, and politicians do not seem to understand the visible and concrete political issues of nutrition.

- Enhance the visibility of nutrition in the sectors. Due, in part, to a lack of clearly defined objectives based on an analysis of the problem by sector, there is little ownership of nutrition and no nutrition indicators are monitored at sectoral level.

- Insufficient financial and human resources are allocated for interventions in nutrition. On the strategic level, appropriation of funds for sectors key to nutrition is lacking and gives rise to two major challenges: (1) sectoral institutionalization of nutrition; and (2) strengthening of multisectorality.

- Strengthening the financial stability of the CLM is essential. As long as the CLM budget is included in the investment budget, its allocations depend on political will. Although this gives the CLM the advantage of being assessed on its performance, it remains vulnerable as it evolves in an environment of uncertainty; its survival depends on political interest in policies related to nutrition issues.

- Due to its institutional anchorage in the Prime Minister's office, the CLM is well positioned to lead on implementation of a multisector approach. However, the CLM relies on BEN for the deployment of its mission, and currently, multisectoral coordination is not reflected in BEN's mandate. As a result, multisectoral collaboration efforts have been relegated to the sidelines at national, regional, departmental, and local levels. It is imperative to reverse this situation by extending BEN's mandate beyond implementation of the PRN. 


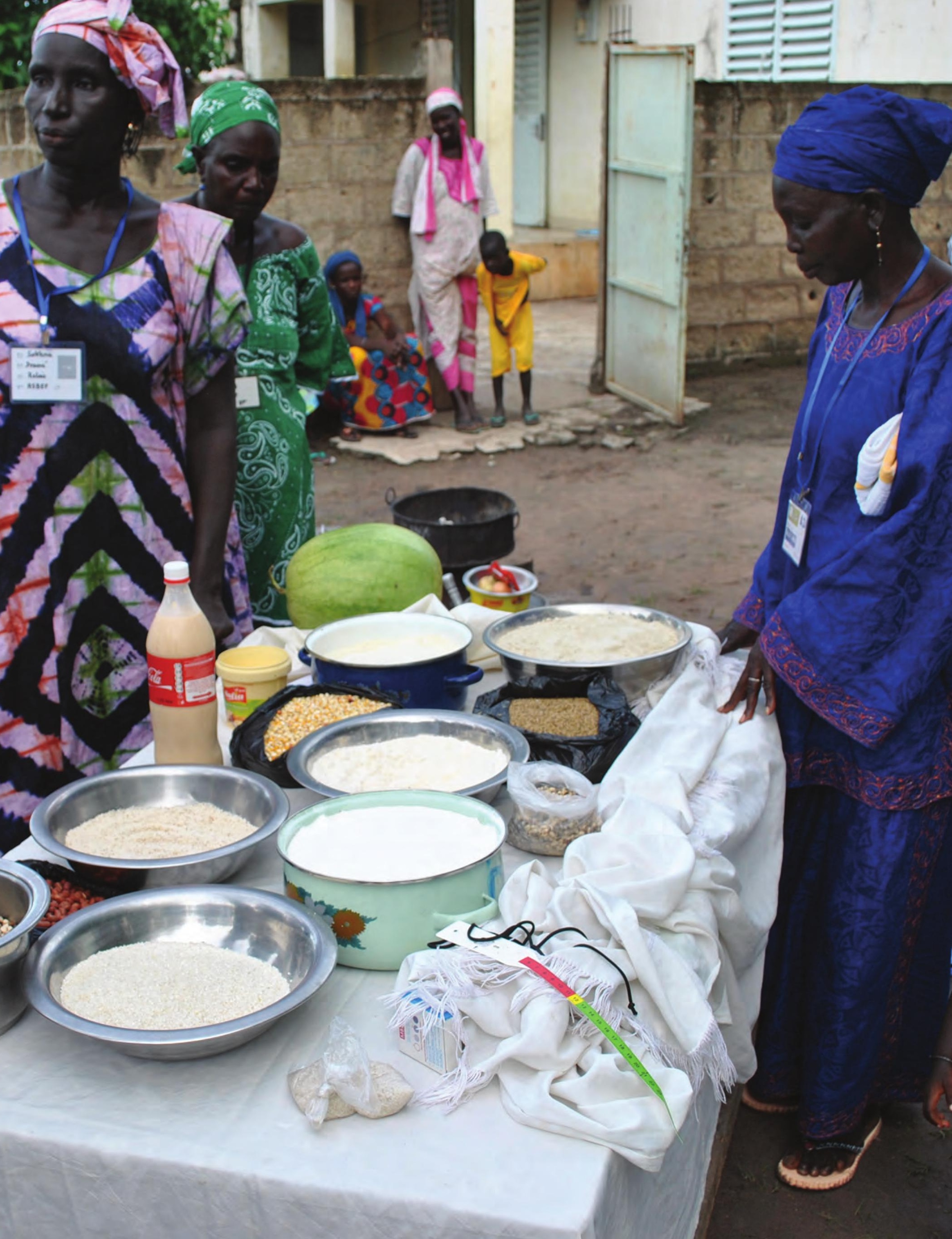




\section{Stakeholders of the Nutrition Sector}

\section{KEY POINTS}

- The nutrition sector has grouped national and international stakeholders into six categories (the government of Senegal and state services, parastatal agencies, United Nations agencies and multilateral organizations, INGOs and NGOs, the private sector, and the academic and research sector)
- The stakeholders of the nutrition sector are involved in various nutrition intervention categories: "nutrition", IYCF, behavior change communication (BCC), food security (including social protection), health and sanitation, and nutrition governance

- The IOCA focused on CLM, BEN, and BERs and ministerial entities DAN, DCMS, DAPSA, and MEPA

\section{Stakeholders of the Nutrition Sector}

Senegal's nutrition sector stakeholders can be categorized into six groups: (1) the government of Senegal and state services; (2) parastatal agencies; (3) United Nations agencies and multilateral organizations; (4) INGOs and NGOs; (5) the private sector; and 6) the academic and research sector. Interventions can also be categorized into "nutrition" (here referring to micronutrient supplementation, malnutrition screening and management, and deworming), IYCF, BCC, food security (including social protection), health and sanitation services, and nutrition governance. While some important stakeholders, such as the CLM, are catalysts across multiple intervention categories, others (such as the National Authority for Reclamation and Development of Land of the River Basin Delta and Valleys of Rivers Senegal (SAED) and the Food Technology Institute (ITA)) lead in only a few. The breadth of focus depends on the constituents and mission of the stakeholder in question.

Table 3 presents most of the stakeholders involved in key nutrition interventions in Senegal, according to a mapping conducted by REACH and the CLM in 2015. 


\begin{tabular}{|c|c|c|c|c|}
\hline \multicolumn{2}{|c|}{ Key intervention } & \multirow{2}{*}{$\begin{array}{l}\text { Catalyst } \\
\text { CLM, HKI, UNICEF, } \\
\text { ANPECPT }\end{array}$} & \multirow{2}{*}{$\begin{array}{l}\text { Implementing actors } \\
\text { Ministry of Health and } \\
\text { Social Action (MSAS), CLs, } \\
\text { CBOs }\end{array}$} & \multirow{2}{*}{$\begin{array}{l}\text { Donor } \\
\text { USAID, BACDI, World } \\
\text { Bank, Hunger Project } \\
\text { Global Office, USDA, } \\
\text { ECHO/EU, DFATD, } \\
\text { IntraHealth }\end{array}$} \\
\hline Nutrition & $\begin{array}{l}\text { Vitamin A, iron, and folic } \\
\text { acid supplementation }\end{array}$ & & & \\
\hline & $\begin{array}{l}\text { Fight against malnutrition } \\
\text { (screening and } \\
\text { management) }\end{array}$ & $\begin{array}{l}\text { CLM, HKI, UNICEF, } \\
\text { ANPECPT, WFP, } \\
\text { AECID }\end{array}$ & MSAS, NGOs & $\begin{array}{l}\text { Government of Senegal } \\
\text { (GS), USAID, BACDI, } \\
\text { AECID, World Bank, } \\
\text { Hunger Project Global } \\
\text { Office, MDG Fund, ECHO/ } \\
\text { EU, DFATD, IntraHealth }\end{array}$ \\
\hline & Deworming & $\begin{array}{l}\text { CLM, HKI, UNICEF, } \\
\text { ANPECPT, WFP, } \\
\text { AECID }\end{array}$ & MEN, NGOs & $\begin{array}{l}\text { GS, USAID, BACDI, } \\
\text { AECID, World Bank, } \\
\text { Hunger Project Global } \\
\text { Office, MDG Fund, ECHO/ } \\
\text { EU, DFATD, IntraHealth }\end{array}$ \\
\hline & Growth monitoring & $\begin{array}{l}\text { CLM, HKI, UNICEF, } \\
\text { ANPECPT, WFP, } \\
\text { AECID }\end{array}$ & MSAS, NGOs & $\begin{array}{l}\text { AECID, USAID, GS, The } \\
\text { Hunger Project Global } \\
\text { Office, World Bank, BACDI, } \\
\text { ECHO/EU, DFATD }\end{array}$ \\
\hline & $\begin{array}{l}\text { Small-scale and } \\
\text { community fortification }\end{array}$ & CLM, ITA, SAED & MSAS, NGOs & $\begin{array}{l}\text { GS, AECID, World Bank, } \\
\text { USAID }\end{array}$ \\
\hline \multirow[t]{2}{*}{ IYCF } & EBF & $\begin{array}{l}\text { HKI, UNICEF, CLM, } \\
\text { ANPECTP }\end{array}$ & MSAS, NGO & $\begin{array}{l}\text { AECID, USAID, GS, } \\
\text { Hunger Project Global } \\
\text { Office, World Bank, BACDI, } \\
\text { ECHO/EU, DFATD }\end{array}$ \\
\hline & IYCF (6-23 months) & HKI, UNICEF, CLM & MSAS, NGO & $\begin{array}{l}\text { AECID, USAID, GS, } \\
\text { Hunger Project Global } \\
\text { Office, World Bank, BACDI, } \\
\text { ECHO, DFATD }\end{array}$ \\
\hline \multirow[t]{2}{*}{$\mathrm{BCC}$} & $\begin{array}{l}\text { Nutritional Education } \\
\text { Programme }\end{array}$ & $\begin{array}{l}\text { FAO, HKI, CLM, ITA, } \\
\text { Ecole Supérieure } \\
\text { Polytechnique, } \\
\text { ENFEFS, IEF, SNEIPS }\end{array}$ & MSAS, MEN, MAER, MEPA & $\begin{array}{l}\text { AECID, GS, World Bank, } \\
\text { IntraHealth, BACDI, USAID }\end{array}$ \\
\hline & $\begin{array}{l}\text { Essential Family } \\
\text { Practices (EFP) }\end{array}$ & $\begin{array}{l}\text { FAO, UNICEF, CLM, } \\
\text { HKI }\end{array}$ & MSAS, MEN, MAER, MEPA & $\begin{array}{l}\text { AECID, USAID, GS, } \\
\text { Hunger Project Global } \\
\text { Office, BM, IntraHealth, } \\
\text { BACDI, MDG Fund, } \\
\text { DFATD, ECHO }\end{array}$ \\
\hline \multirow[t]{3}{*}{$\begin{array}{l}\text { Food } \\
\text { security }\end{array}$} & $\begin{array}{l}\text { Development of family } \\
\text { farming (agriculture, } \\
\text { animal breeding, and } \\
\text { fishing) }\end{array}$ & $\begin{array}{l}\text { FAO, IFPRI, Cives } \\
\text { Mundi, ITA, HKI, CLM, } \\
\text { WFP, IFDC }\end{array}$ & MAER, MEPA, NGOs & $\begin{array}{l}\text { Belgium, Sweden, Brazil, } \\
\text { GS, DFID, AECID, IFAD, } \\
\text { Spanish Fiduciary Funds, } \\
\text { Caritas International, } \\
\text { USAID, BACDI }\end{array}$ \\
\hline & $\begin{array}{l}\text { Biofortification of } \\
\text { household food }\end{array}$ & ITA & $\begin{array}{l}\text { MAER, MEPA, MSAS, } \\
\text { NGOs }\end{array}$ & USAID, Manos Unados \\
\hline & $\begin{array}{l}\text { Social net programs for } \\
\text { vulnerable groups }\end{array}$ & $\begin{array}{l}\text { IFPRI, UNICEF, FAO, } \\
\text { CLM }\end{array}$ & $\begin{array}{l}\text { Ministry for Women, } \\
\text { Children and the Family, } \\
\text { MAER, MEPA, MSAS, } \\
\text { General Delegation for } \\
\text { Social Protection and } \\
\text { National Solidarity, NGOs }\end{array}$ & $\begin{array}{l}\text { DFID, Brazil, French } \\
\text { Committee, JICA, USAID, } \\
\text { World Bank }\end{array}$ \\
\hline
\end{tabular}

(continued on next page) 
TABLE 3: Nutrition Sector Stakeholders (continued)

\begin{tabular}{|c|c|c|c|c|}
\hline \multicolumn{2}{|c|}{ Key intervention } & \multirow{2}{*}{$\begin{array}{l}\text { Catalyst } \\
\text { HKI, UNICEF, CLM, } \\
\text { AGETIF, JICA, } \\
\text { AGRICE }\end{array}$} & \multirow{2}{*}{$\begin{array}{l}\text { Implementing actors } \\
\text { Ministry for Hydraulics and } \\
\text { Sanitation, MSAS, CLM, } \\
\text { NGOs }\end{array}$} & \multirow{2}{*}{$\begin{array}{l}\text { Donor } \\
\text { USAID, Hunger } \\
\text { Project Global Office, } \\
\text { BACDI, UNICEF, JICA, } \\
\text { Luxembourg, Sweden, } \\
\text { Norway, Helvetas }\end{array}$} \\
\hline $\begin{array}{l}\text { Healthcare } \\
\text { services } \\
\text { and health } \\
\text { environment }\end{array}$ & $\begin{array}{l}\text { Promotion of hygiene } \\
\text { (hand washing and } \\
\text { community-led total } \\
\text { sanitation (CLTS), use of } \\
\text { latrines, household water } \\
\text { treatment) }\end{array}$ & & & \\
\hline & $\begin{array}{l}\text { Management of diarrhea } \\
\text { and acute respiratory } \\
\text { infections (ARI) }\end{array}$ & $\begin{array}{l}\text { HKI, MI, UNICEF, } \\
\text { CLM, ChildFund }\end{array}$ & MSAS, CLM, NGOs & $\begin{array}{l}\text { GS, IntraHealth, World } \\
\text { Bank, USAID, DFATD, } \\
\text { MDG Fund, ECHO, AECID, } \\
\text { TECK Resources }\end{array}$ \\
\hline & $\begin{array}{l}\text { Reproductive health } \\
\text { program }\end{array}$ & UNICEF & MSAS & USAID \\
\hline & $\begin{array}{l}\text { Pregnancy follow-up } \\
\text { (prenatal consultation, } \\
\text { assisted delivery, } \\
\text { postnatal consultation) }\end{array}$ & $\begin{array}{l}\text { UNICEF, WHO, } \\
\text { UNFPA }\end{array}$ & MSAS, CLM, NGOs & $\begin{array}{l}\text { USAID, Hunger Project } \\
\text { Global Office, ES, World } \\
\text { Bank, IntraHealth, DFATD, } \\
\text { Norway, France }\end{array}$ \\
\hline & $\begin{array}{l}\text { Prevention of disease } \\
\text { (immunization, PMTCT) }\end{array}$ & $\begin{array}{l}\text { UNICEF, WHO, CLM, } \\
\text { ANPECTP }\end{array}$ & MSAS, NGOs & $\begin{array}{l}\text { USAID, Hunger Project } \\
\text { Global Office, GS }\end{array}$ \\
\hline
\end{tabular}

Source: CLM/REACH 2010. Presentation on the Cartography of Stakeholders and Key Nutrition Interventions in Senegal, Dakar, July $28,2015$.

Note: $\mathrm{PMTCT}=$ prevention of mother-to-child transmission. See Acronym List for full names of organizations.

\section{Organizations Targeted by the Institutional and Organizational Analysis}

This study focused foremost on the agencies responsible for implementing nutrition policy in Senegal, namely the CLM and its technical arm, the BEN. However, given the multidimensional nature of nutrition, the following organizations were also considered: The DAN, which is part of the MSAS, the DCMS which is part of the MEN, the DAPSA which is part of the MAER, and the Study and Planning Unit (CEP) of the MEPA. These organizations, discussed below, are referred to throughout this report as "units of analysis".

\section{The CLM and BEN}

Established in 2001, the CLM is under the direct authority of the Prime Minister and chaired by his Chief of Staff. It is composed of representatives from key technical ministries involved in nutrition (health, education, agriculture, animal breeding, industry, and trade), as well as representatives from the Association of Mayors, the Association of Rural Councillors, and civil society. In addition to the BEN, the CLM is equipped with a technical sub-Committee (Senegalese Committee for Micronutrient Food Fortification).
The BEN is in charge of implementing national nutrition programs (table 4). It also manages the BERs and coordinates implementation of community-based nutrition activities by CLs in partnership with AECs. BEN's national nutrition program activities are divided along three main axes:

- Community Integrated Management of Childhood Illnesses (PCIME-C)/ Community Management of Acute Malnutrition (CMAM)

- Treatment and prevention of micronutrient deficiencies

- Promotion of nutrition-related intersectoral interventions.

\section{The Food and Nutrition Division (DAN)}

The DAN of the Reproductive Health and Child Survival Department (DSRSE) is part of the MSAS. Created in 2012 following an institutional reorganization that split the Division of Food, Nutrition, and Child Survival (DANSE) into two entities, DAN reflects government resolve to strengthen nutrition programming within the health sector. DAN is mandated to prepare and implement national food and nutrition policies in Senegal, in collaboration with other ministries and various 
TABLE 4: Projects and programs implemented under the authority of the BEN

\begin{tabular}{|c|c|}
\hline Intervention & Objective \\
\hline $\begin{array}{l}\text { PRN } \\
\text { (2007 to date) }\end{array}$ & $\begin{array}{l}\text { Strengthen the fight against malnutrition and reduce } \\
\text { micronutrient deficiencies, especially iron, vitamin A, and iodine }\end{array}$ \\
\hline $\begin{array}{l}\text { Universal Salt lodization Project (PIUS) } \\
(2009-14)\end{array}$ & $\begin{array}{l}\text { Contribute to the lasting elimination of disorders related to iodine } \\
\text { deficiencies, with universal salt iodization for human and animal } \\
\text { consumption as the basic strategy }\end{array}$ \\
\hline $\begin{array}{l}\text { Programme for the Enhancement of [Food] Fortification } \\
\text { in Senegal (PRF) } \\
(2006-11)\end{array}$ & $\begin{array}{l}\text { Provide the population with foods fortified with micronutrients } \\
\text { such as vitamin A, iron, and folic acid }\end{array}$ \\
\hline PASAV (Since 2013) & $\begin{array}{l}\text { Improve food security of vulnerable households by supporting } \\
\text { market-garden, animal breeding, and other activities which } \\
\text { increase availability of and access to nutrient dense foods }\end{array}$ \\
\hline $\begin{array}{l}\text { Results-Based Financing (RBF) } \\
\text { (2013-18) }\end{array}$ & Improve demand for maternal health care \\
\hline $\begin{array}{l}\text { Child Targeted Nutrition and Social Transfers (NETS) } \\
(2009-11)\end{array}$ & $\begin{array}{l}\text { Strengthen the resilience of communities and families to the } \\
\text { socioeconomic crisis and improve their nutritional situation }\end{array}$ \\
\hline $\begin{array}{l}\text { Joint Nutrition, Child, and Food Security Programme } \\
\text { (NESA) } \\
(2009-12)\end{array}$ & $\begin{array}{l}\text { Help improve the monitoring of acute malnutrition at the } \\
\text { community level }\end{array}$ \\
\hline
\end{tabular}

Source: CLM, undated.

technical and financial partners that are active in the nutrition sector. It is organized into three offices:

1. A Food Office responsible for all activities related to food security, the codex alimentarius, EBF, IYCF, promotion of healthy dietary practices, and micronutrient supplementation

2. A Nutrition Office in charge of communication activities (sensitization, Information, Education and Communication (IEC), and BCC), nutrition surveys, and prevention, screening, and management of nutrition for children up to age 5 and pregnant and nursing women

3. A Nutritional Surveillance Office, which ensures partnerships with relevant programs and conducts inventory monitoring, data compilation and processing, and sentinel site surveillance

DAN can be credited with the following major achievements:

- Preparation and adoption of Moderation Acute Malnutrition (MAM) plans in response to the nutrition and food crisis in regions with CLM support

- Equipment of service delivery points with materials needed for growth monitoring
- Supplying essential PECMAS products to service delivery points

- Implementation of actions to prevent chronic malnutrition and to manage acute malnutrition in pregnant and nursing women in 10 medical regions

- Proper execution of a Standardized Monitoring and Assessment of Relief and Transitions (SMART) Survey

- Organization of Child Survival Days (JSE) in collaboration with the Child Survival Division and execution of the JSE coverage survey.

\section{The School Health Checks Division (DCMS)}

DCMS is a division of the MEN, which considers health and nutrition necessary preconditions for teaching and learning. DCMS activities are implemented in elementary, junior secondary, and secondary schools, as well as in general education, technical and vocational training, and nonformal education contexts.

The Education and Training Equity and Transparency Quality Improvement Programme (PAQUET-EF) is the primary vehicle through which MEN promotes nutrition. DCMS works in partnership with the CLM on implementing health and nutrition activities in schools 
to achieve PAQUET-EF objectives. Interventions are centered on training, communication (social mobilization, IEC, and BCC), advanced approaches for the screening of infections and disorders, research-based action, and monitoring and assessment. For example, in the 2014-15 school year, activities focused on reduction of iron deficiency (advocacy and iron acquisition), reduction of iodine deficiency and associated disorders, and development of teaching aids (posters promoting iodized salt; health, nutrition, and environment exercise books). These activities were based on an action plan funded by the CLM.

In addition to its partnership with the CLM, DCMS defines, implements, coordinates, monitors, supervises, and evaluates health and nutrition activities in conjunction with focal points from other MEN divisions and with the support of the MSAS and partners.

All DCMS activities are guided by a policy document that serves as a reference framework to harmonize and coordinate interventions relating to health, nutrition, and the environment within the education sector.

\section{Ministry of Livestock and Animal Husbandry (MEPA)}

MEPA has been restructured to improve its management of the sector's development policy. New divisions, including the General Secretariat and the Department of Animal Industries, have been established.

MEPA is organized around divisions attached to the Office of the Minister and those attached to the General Secretariat. The General Secretariat includes Services, Administrations and Directorates General.

MEPA's National Livestock Development Plan, developed within the framework of the PSE, includes strategic objectives to accelerate development of live- stock subsectors to improve food security, increase income, and safeguard natural resources.

MEPA contributes to nutrition-sensitive interventions for food security, such as social safety net programs for vulnerable groups, poultry farming, family farming and small ruminant farming.

\section{Agricultural Statistics Analysis and Forecast Department (DAPSA)}

Created in 2001 to replace the L'Unité de Politique Agricole (Agricultural Policy Unit) (UPA), DAPSA is a department of the MAER. It comprises an administrative office and three divisions: Agricultural Documentation and Information, Projects and Programs, and Analysis and Forecasting. In collaboration with other directorates and departments of the Ministry, it is responsible for the development, monitoring, and assessment of agricultural development policies and strategies, as well as for fundraising for projects and programs.

In 2014, multiple ministries, partners, and resource persons undertook a joint review of the agricultural sector with respect to income generation and achievement of food and nutrition security. The resultant long-term vision for the sector was reflected in the Loi d'Orientation Agro-Sylvo-Pastorale (Agro-Sylvo-Pastoral Orientation Law) (LOASP) 2004-2024. The LOASP currently informs development and implementation of operational MAER programs such as the Programme National de Développement Agricole (National Agricultural Development Programme) (PNDA), the 2009-15 Lettre de Politique Sectorielle de l'Environnement et des Ressources Naturelles (Environment and Natural Resources Sectoral Policy Letter) (LPSERN) and the 2007 Plan d'Action pour le Développement de la Pêche et de l'Aquacultur (Action Plan for Fishing and Aquiculture Development) (PADPA). 
- The CLM's institutional grounding makes it a key actor for implementation of a multisectoral approach. However, the context has changed significantly since the creation of the CLM and the BEN, and today the sector needs strong leadership specifically with respect to coordination and collaboration.

- Because the decree establishing the BEN focused its mandate on the PRN's implementation, and because the CLM relies on the BEN for deployment of its mission, the BEN's mandate should be expanded to increase its legitimacy. Currently, multisectoral coordination is not reflected in the mandate, and as such is relegated to the sidelines at national, regional, departmental, and local levels. Even though the BEN is implicitly working in this direction, its efforts are still inadequate and fall short of the increasingly high expectations for stronger leadership and maximum multisectorality and collaboration in the sector.

- The CLM budget is included in the investment budget, and its budget allocations depend on political will. The CLM should seek to secure the continued commitment of political authorities to increase its budget allocations and government's investment in nutrition. 


\section{Stakeholder Contributions to Improving Nutrition}

\section{KEY POINTS}

- Senegal is on course to achieve the WHA targets for reducing wasting and overweight in children.

- However, much work remains to be done: The coverage of targets by various interventions is still uneven and varies between 100 percent and 1 percent. Moreover, Senegal is off-track for achieving the WHA goals for stunting, EBF, and anemia.
- The CLM is in the forefront of nutrition interventions because of its involvement in different activities and its engagement with key ministries.

- Relative to other public sector stakeholders, CLs contribute the most funding to nutrition-specific interventions (assisted by the CLM)

\section{Contribution of Nutrition Sector Stakeholders to Improving Nutritional Status}

Senegal identifies the fight against malnutrition as a priority and is on course to achieve the WHA targets for reducing wasting and overweight in children. However, Senegal is unlikely to reach other targets-namely a 40 percent reduction in the number of stunted children, a 50 percent increase in the practice of EBF, and a 50 percent reduction in the prevalence of anemia among women of childbearing age-unless it redoubles its efforts. Implementation of the PSMN offers hope of reversing these trends.
Table 5 shows the contribution of various stakeholders, including this study's units of analysis, to the implementation of interventions key for improving nutrition.

In terms of coverage, there is substantial variation depending on the region and intervention. Coverage is 100 percent for vitamin A supplementation, screening for acute malnutrition, and deworming of children; 26 percent for home-based fortification; 37 percent for MAM management; and 37 percent for ICYF. Rates for the remaining interventions are less than 25 percent. Despite efforts made by various stakeholders, target 
coverage is becoming increasingly urgent as interventions scale up.

When implementation is assessed in terms of funding, the significant role played by local government is highlighted. Figure 2 provides a breakdown of contributions to nutrition-specific interventions by various key public sector nutrition stakeholders, with CLs providing the most funding (42 percent), followed by the
MSAS (30 percent), and the CLM through the Prime Minister's Office (19 percent).

That said, it is important to note that CLs, MEN, and MSAS all receive support from the CLM for specific nutrition actions in addition to using their own resources. Given this outsourcing approach, the financial role of the CLM is in fact larger than what is shown in figure 2.

TABLE 5: Key Interventions and Coverage of Target Groups at the National Level

\begin{tabular}{|c|c|c|c|c|}
\hline \multicolumn{2}{|c|}{ Intervention } & \multirow{2}{*}{$\begin{array}{l}\text { Target group } \\
\text { Children 6-59 } \\
\text { months }\end{array}$} & \multirow{2}{*}{$\begin{array}{c}\text { Overall } \\
\text { coverage rate } \% \\
100\end{array}$} & \multirow{2}{*}{$\begin{array}{l}\text { Stakeholders } \\
\text { UNICEF, HKI, CLM, ANPECTP, MSAS, CLs, } \\
\text { NGOs, community }\end{array}$} \\
\hline \multirow[t]{10}{*}{ Nutrition } & $\begin{array}{l}\text { Vitamin A } \\
\text { supplementation }\end{array}$ & & & \\
\hline & $\begin{array}{l}\text { Vitamin A, iron, } \\
\text { and folic acid } \\
\text { supplementation }\end{array}$ & Pregnant women & 9 & $\begin{array}{l}\text { CLM, HKI, UNICEF, ANPECPT, WFP, AECID, } \\
\text { MSAS, NGOS }\end{array}$ \\
\hline & $\begin{array}{l}\text { Home-based } \\
\text { fortification }\end{array}$ & $\begin{array}{l}\text { Children 6-23 } \\
\text { months }\end{array}$ & 26 & $\begin{array}{l}\text { CLM, ITA, SAED } \\
\text { MSAS, NGOs }\end{array}$ \\
\hline & $\begin{array}{l}\text { Screening for acute } \\
\text { malnutrition }\end{array}$ & $\begin{array}{l}\text { Children 6-59 } \\
\text { months }\end{array}$ & 100 & \multirow[t]{3}{*}{$\begin{array}{l}\text { CLM, HKI, UNICEF, ANPECPT, WFP, AECID, } \\
\text { MSAS, NGOs }\end{array}$} \\
\hline & $\begin{array}{l}\text { Management of } \\
\text { Severe Acute } \\
\text { Malnutrition (SAM) }\end{array}$ & $\begin{array}{l}\text { Children 6-59 } \\
\text { months }\end{array}$ & 9 & \\
\hline & $\begin{array}{l}\text { Management of } \\
\text { MAM }\end{array}$ & $\begin{array}{l}\text { Children 6-59 } \\
\text { months }\end{array}$ & 37 & \\
\hline & \multirow[t]{2}{*}{ Deworming } & $\begin{array}{l}\text { Children 12-59 } \\
\text { months }\end{array}$ & 100 & $\begin{array}{l}\text { CLM, HKI, UNICEF, ANPECPT, WFP, AECID, } \\
\text { MSAS, MEN, NGOS }\end{array}$ \\
\hline & & $\begin{array}{l}\text { Children } 5 \text { to } 12 \\
\text { years }\end{array}$ & 99 & CLM, MEN, NGOs \\
\hline & $\begin{array}{l}\text { Growth monitoring } \\
\text { and promotion }\end{array}$ & $\begin{array}{l}\text { Children } 0-23 \\
\text { months }\end{array}$ & 21 & $\begin{array}{l}\text { CLM, HKI, UNICEF, ANPECPT, WFP, AECID, } \\
\text { MSAS, NGOS }\end{array}$ \\
\hline & $\begin{array}{l}\text { Small-scale } \\
\text { and community } \\
\text { fortification }\end{array}$ & $\begin{array}{l}\text { Children 6-59 } \\
\text { months }\end{array}$ & 2 & $\begin{array}{l}\text { CLM, ITA, SAED } \\
\text { MSAS, NGOS }\end{array}$ \\
\hline \multirow[t]{4}{*}{ IYCF } & \multirow[t]{2}{*}{ EBF } & $\begin{array}{l}\text { Breastfeeding } \\
\text { women } 0-6 \text { months }\end{array}$ & 14 & \multirow[t]{2}{*}{$\begin{array}{l}\text { HKI, UNICEF, CLM, ANPECTP } \\
\text { MSAS, NGOS }\end{array}$} \\
\hline & & Pregnant women & 9 & \\
\hline & \multirow[t]{2}{*}{$\begin{array}{l}\text { IYCF } \\
\text { (6-23 months) }\end{array}$} & $\begin{array}{l}\text { Breast-feeding } \\
\text { women } 6-23 \\
\text { months }\end{array}$ & 37 & \multirow[t]{2}{*}{$\begin{array}{l}\text { HKI, UNICEF, CLM } \\
\text { MSAS, NGOs }\end{array}$} \\
\hline & & $\begin{array}{l}\text { Breast-feeding } \\
\text { women } 0-6 \text { months }\end{array}$ & 1 & \\
\hline \multirow[t]{2}{*}{$\mathrm{BCC}$} & PRN & $\begin{array}{l}\text { Mothers and } \\
\text { nannies of children } \\
0-59 \text { months }\end{array}$ & 11 & \multirow[t]{2}{*}{$\begin{array}{l}\text { FAO, HKI, CLM, ITA, Ecole Supérieure } \\
\text { Polytechnique, ENFEFS, IEF, SNEIPS, } \\
\text { MSAS, MEN, MAER, MEPA }\end{array}$} \\
\hline & EFP & $\begin{array}{l}\text { Mothers and } \\
\text { nannies of children } \\
0-59 \text { months }\end{array}$ & 13 & \\
\hline
\end{tabular}


TABLE 5: Key Interventions and Coverage of Target Groups at the National Level (continued)

\begin{tabular}{|c|c|c|c|c|}
\hline \multicolumn{2}{|l|}{ Intervention } & \multicolumn{3}{|c|}{ Overall } \\
\hline \multirow[t]{7}{*}{$\begin{array}{l}\text { Healthcare } \\
\text { services } \\
\text { and health } \\
\text { environment }\end{array}$} & $\begin{array}{l}\text { Promotion } \\
\text { of hygiene } \\
\text { (handwashing } \\
\text { and CLTS, use } \\
\text { of latrines, and } \\
\text { household water } \\
\text { treatment) }\end{array}$ & $\begin{array}{l}\text { Mothers and } \\
\text { nannies of children } \\
0-59 \text { months }\end{array}$ & $10 \%$ & $\begin{array}{l}\text { HKI, UNICEF, CLM, AGETIP, JICA, HYGENA, } \\
\text { AGRICE, Ministry of Hydraulics and } \\
\text { Sanitation, MSAS, CLM, NGO }\end{array}$ \\
\hline & $\begin{array}{l}\text { Diarrhea and ARI } \\
\text { management }\end{array}$ & $\begin{array}{l}\text { Mothers and } \\
\text { nannies of children } \\
0-59 \text { months }\end{array}$ & $3 \%$ & $\begin{array}{l}\text { HKI, MI, UNICEF, CLM, ChildFund } \\
\text { MSAS, CLM, NGO }\end{array}$ \\
\hline & \multirow{2}{*}{$\begin{array}{l}\text { Reproductive } \\
\text { health program }\end{array}$} & Women 15-49 & $6 \%$ & \multirow[t]{2}{*}{ UNICEF, MSAS } \\
\hline & & Pregnant women & $<1 \%$ & \\
\hline & $\begin{array}{l}\text { Pregnancy } \\
\text { monitoring } \\
\text { (prenatal } \\
\text { consultation, } \\
\text { assisted delivery, } \\
\text { postnatal } \\
\text { consultation }\end{array}$ & $\begin{array}{l}\text { Pregnant and } \\
\text { nursing women }\end{array}$ & $8 \%$ & $\begin{array}{l}\text { UNICEF, WHO, UNFPA } \\
\text { MSAS, CLM, NGO }\end{array}$ \\
\hline & $\begin{array}{l}\text { Disease prevention } \\
\text { (immunization, } \\
\text { PMTCT) }\end{array}$ & $\begin{array}{l}\text { Children aged 0-59 } \\
\text { months }\end{array}$ & $9 \%$ & $\begin{array}{l}\text { UNICEF, WHO, CLM, ANPECTP } \\
\text { MSAS, NGO }\end{array}$ \\
\hline & & $\begin{array}{l}\text { Pregnant and } \\
\text { nursing women }\end{array}$ & $16 \%$ & \\
\hline
\end{tabular}

Source: Based on CLM and REACH, Presentation on the Mapping of Stakeholders and Key Nutrition Interventions, Dakar, Senegal, July $28,2015$. Note: $\mathrm{PMTCT}=$ prevention of mother-to-child transmission. See Acronym List for full names of organizations.

FIGURE 2: Funding Provided by Public Sector Nutrition Stakeholders for the Implementation of NutritionSpecific Interventions

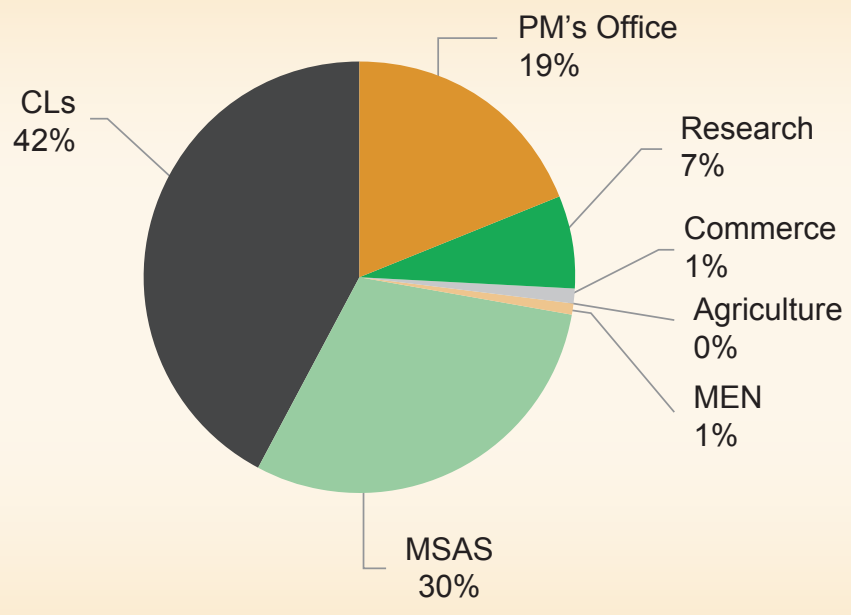

Source: Offosse N. 2018 


\section{Organizational Capacities of the Nutrition Sector}

\section{KEY POINTS}

- The organizational structure of all the units of analysis derives from the decrees or orders establishing them.

- The organizational structure of BEN should be adapted to the new challenges (coordination, communication, and security of resources) and expectations of the nutrition sector.

- New technical units (such as governance and fundraising) and a revamping of the organizational structure will enable BEN to keep pace with the changes in the sector.

- DCMS should improve local effectiveness and efficiency by strengthening its structure at the decentralized level. MEPA is already aware of the need to redefine the missions and attributes of the various divisions to avoid duplication and ensure more efficiency. Services on the ground are inadequate.
- In the absence of a career plan, BEN should implement talent retention strategies, such as continuous capacity-building, valuing of staff contribution, fostering creativity, and internal collaboration.

- Only 50 percent of the positions at DAN are filled because of lack of staff and weak skills for DAN's mission.

- The human resource gap at MEPA is huge, and despite efforts to recruit staff, it is believed that only about 40 percent of staff requirements could be met. Staff is aging and will need to be replaced.

- The ministerial entities are faced with staff shortages because of the irregularity of recruitment for the civil service.

- Lack of human resources specialized in nutrition affects all the units of analysis at both the central and decentralized levels. 
This section discusses organizational capacities of the units of analysis. It covers the following topics:

- Organizational structure

- Human resources

- Financial management

- Program management

- Intra- and interorganizational relations

\section{Organizational Structure}

Organizational structure affects the capacity of an institution to achieve its mission through the way work is divided and the way roles and responsibilities are assigned. Typically, the organizational structure of public sector institutions is influenced by the legislative decrees and orders governing those institutions. This is the case for the units of analysis investigated by this study, as described below.

\section{The Food and Nutrition Division (DAN)}

DAN is led by a Head of Division and has three offices: the Food Office, the Nutrition Office, and the Nutritional Surveillance Office. DAN's existing organizational chart does not take operations into account. DAN has a food, nutrition, and child survival supervisor at the regional level and a focal point at health district level. The Division is not fully staffed.

\section{The School Health Checks Division (DCMS)}

DCMS has a strong structure at the central level. Regionally, however, it faces challenges as the complexity of the education sector makes coordinating decentralized entities difficult. These include teams performing medical check-ups in schools, School Inspection Offices (IA), Education and Training Inspections (IEF), and additional focal points. Each of these entities faces its own set of challenges; for example, the 2014 MEN Report on the State of Education found that "on the ground, the IEF is struggling to fulfill its missions of piloting, coordination, monitoring-assessment and supervision of school activities because of conflicts between inspectors and school principals, and because coordination between primary and junior secondary education is lacking" (MEN 2014).

\section{Agricultural Statistics Analysis and Forecast Department (DAPSA)}

One of the eight departments within the MAER, DAPSA's primary function is program and project planning, development, and monitoring and assessment. DAP$\mathrm{SA}$ is challenged by the inconsistent breakdown of its organizational structure at the decentralized level. The DAPSA regional divisions, which play an essential role in the production of agricultural statistics, rely on the Regional Rural Development Departments (DRDR), which represent all national directorates and are not directly linked hierarchically to MAER. This remains a source of dysfunction for DAPSA in the conduct of surveys.

\section{Ministry of Livestock and Animal Husbandry (MEPA)}

MEPA's current organizational structure includes a General Secretariat, a Study and Planning Unit, a Directorate of Animal Industries, a Directorate of Veterinary Services, and a Directorate of Equine Development. There are three hierarchical levels of decentralized technical services: regional animal breeding services, departmental animal breeding services, and animal breeding stations. These services are all individually linked to the central Ministry, but coordination between the services has not been prioritized.

\section{The Bureau Exécutif National (BEN)}

BEN has four units: I'Unité Politique et Stratégie (Policy and Strategy Unit) (UPS); I'Unité Administration et Logistiques (Administration and Logistics Unit) (UAL); l'Unité Financière et Comptable (Financial and Accounts Unit) (UFC); and Unité de Suivi et Appui aux Opérations (Operations, Monitoring and Support Unit) (USO). Notably, the BERs depend on the USO. While functional, these units are understaffed and personnel bear a very heavy workload as a result. (See Human Resources, below.) Originally designed for implemen- 
tation of the PRN, the BEN's structure has evolved progressively to accommodate other projects and programs. An important shortcoming is the failure, thus far, to create, manage, update, and facilitate accessibility to a nutritional information system.

- DCMS should strengthen its structure at decentralized levels (regional and departmental) to ensure an effective presence in the field.

- MEPA should redefine and align the missions and responsibilities of its different divisions to avoid duplication, increase efficiency, and to address the shortage of services in the field. The decentralized technical services of MEPA do the work of four directorates, and there is a problem of translation of services because of their attachment to the Cabinet as opposed to the directorates. The hierarchical nature of MEPA's field services also poses a stumbling block. Specialists should be recruited to analyze MEPA's human resource needs and to propose an organizational chart adapted to a strategic orientation that addresses these limitations.

- BEN's organizational structure should be adapted to the new challenges and expectations of the nutrition sector. Establishing new technical units (such as governance and funding) or reengineering old ones will keep BEN in line with the changing dynamics of the sector. At the regional level, the institutional communication capacities of BER technical teams must be improved.

\section{RECOMMENDATIONS:}

and review the BEN's annual action plans. In addition to these meetings, the CLM has a control and monitoring committee that supervises the activities of the BEN.

BEN is also expected to conduct quarterly reviews with BERs and biannual reviews with TFPs. However, the meetings held at the head office with TFPs have become irregular.

BERs hold monthly coordination meetings and quarterly meetings with AECs. With regional authorities, meetings of Regional Follow-up Committees (CRS) are organized biannually.

\section{RECOMMENDATIONS:}

- As part of the implementation of the new strategic plan, a coordination of actors will be required. As such, it is important for the CLM to strengthen its internal coordination and to conduct a review of its actions as an institution to evaluate implementation of its mandate.

- Biannual exchange meetings on nutrition interventions with TFPs should be reinstated.

DCMS has no operational coordination with the field because MEN staff are not answerable to DCMS. The absence of monitoring mechanisms at the central level is also a challenge.

\section{RECOMMENDATIONS:}

\section{Organizational Coordination Mechanisms}

With the new direction taken by the nutrition sector, there is dire need to strengthen the coordination and interaction of stakeholders. Currently, units of analysis employ the following coordination mechanisms:

The decree creating the CLM provides for statutory meetings held every four months at the invitation of its chairperson. These meetings are organized to validate
MEPA holds conventional coordination meetings and sectoral planning and review workshops every year, with sectoral reviews at the regional level. 
DAN organizes weekly meetings at the central level, quarterly reviews at the regional level, and biannual reviews of participants that participate in food and nutrition programs at the national level (such as state services, decision makers, and beneficiaries).

\section{RECOMMENDATIONS:}

- MEPA should improve the planning of its meetings to cut their number.

- DAN should continue to hold regular meetings at various levels.

\section{Human Resources}

Recruitment in ministries is managed by the Ministry of Civil Service. Placement of personnel is needsbased. As a result, recruitment is irregular and many ministerial entities are often short-staffed. This problem is faced by this study's units of analysis, which are often lacking nutrition specialists at central and decentralized levels. Existing staff's limited knowledge of nutrition restricts efficacy and constrains collaboration and coordination. These and other challenges regarding the quality and quantity of staff within the units of analysis are discussed below.

\section{BEN}

BEN recruitment procedures are stringent, governed by a manual of procedures, and, when required, donor validation. Candidates are recruited through a public call for applications, and the selection process is conducted with the support of a specialized firm or internal committee set up for that purpose. Efforts are made to guarantee the transparency and impartiality of the recruitment process.

Although internal redeployments, including promotions, are possible under the manual of procedures, current human resources procedures do not facilitate career development within the BEN. In the long term, this situation will lead either to the departure of experienced staff members or to weakened staff motivation.

Human resource management within BEN is coordinated by the Adminstration and Logistics Unit, which is itself understaffed. Capacity is further impaired by the manual of procedures mentioned above, which is too large for routine dissemination.

BEN has a multidisciplinary staff of 46 members, 26 percent of whom are women. Although nutrition is the BEN's area of intervention, the ratio of nutritionists to non-nutritionist personnel is low. Per figure 3 , a scant 9 percent of personnel are health and nutrition policy specialists, relative to other types of experts. The deficit is most marked when compared to financial and accounting employees, who comprise a full 50 percent of agency staff. The imbalance is presumably due to the rigorous financial requirements that donors and government have tasked the BEN with meeting.

Many nutrition sector stakeholders have criticized both the BEN and the CLM for hiring too few nutritionists. As such, it should be noted that recruitment of a nutritionist was underway during this assessment.

FIGURE 3: Breakdown of BEN Staff by Training Area

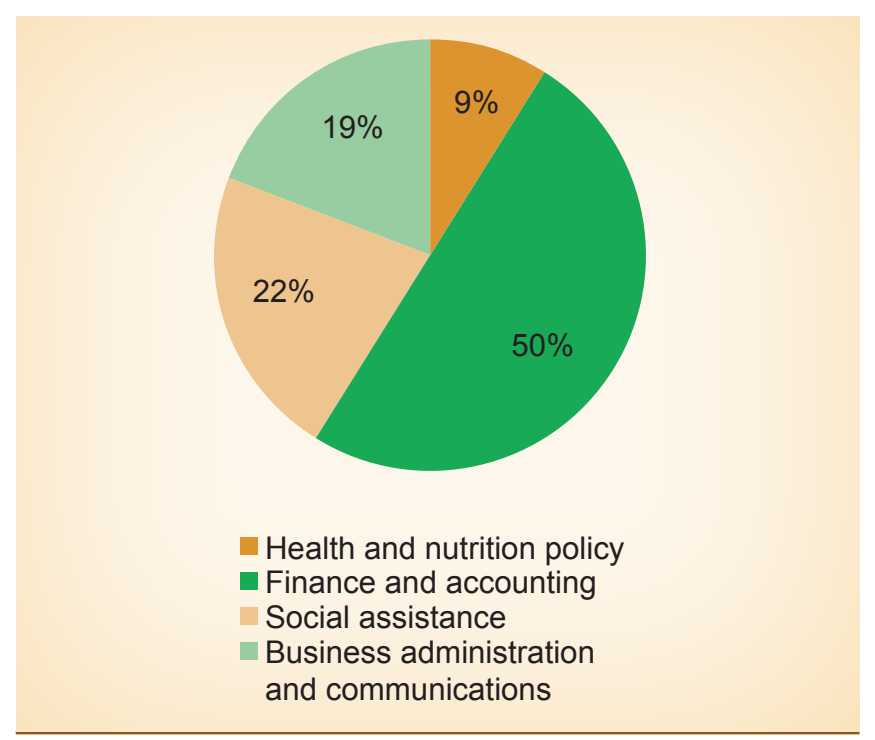

Source: Based on BEN staff list. 


\section{RECOMMENDATIONS:}

- To offset the lack of career development protocol, the BEN should consider strategies for talent retention, such as continuous capacity building, recognition of staff contributions, encouragement of creativity, and internal collaboration.

- BEN should systematically document human resource needs, encourage compliance with the procedural manual, and employ staff trained in human resource management or strengthen the capacities of staff members with skills in that area.

- BEN should hire more personnel with skills in nutrition, specifically nutrition advocacy, network management, public-private partnerships, fundraising, governance, and data processing. BEN should finalize recruitment and deployment for all vacant posts or retrain current staff to fill these roles.

- BEN should create coordination positions attached to a BER for the supervision of activities instead of leaving the BERs to cover several regions with very limited staff.

- BERs should strengthen the capacities of their personnel in human resources, program management, logistics, and procurement and promote the development of nutrition capacity through short training courses, certifications, and part-time university degree programs.

Forty-one percent of BEN's technical and administrative staff is based in the BERs. However, the scope of work and geographic coverage required at the decentralized level indicate that this allotment is insufficient. Notably, a number of posts were unfilled at the BER level during this assessment, ${ }^{4}$ causing excessive workload for interim staff and slowing down operations, including delays in report validation, check signing, and provision for mission expenses.

\section{DAN}

At the DAN, only 50 percent of posts are filled. At the central level, there are eight employees: one doctor, one secretary, one midwife, one senior health technician, three technical assistants in nutrition, and one driver. There is no senior nutritionist.
One of the primary reasons DAN is understaffed is that "nutritionist" is not recognized as a profession by the civil service. As such it holds little appeal as a career choice. Even the technical assistants in nutrition are external consultants hired to support specific projects. Their availability depends completely on resources provided by financial partners. The lack of staff is most pronounced in the peripheral regions, as personnel are concentrated near Dakar and Thiès. (DSRSE 2014).

\section{RECOMMENDATIONS:}

- DAN, through the DSRSE, should request that MSAS authorize an increase in skilled staff specializing in nutrition, public health, or both, as well as staff holding expertise in policy development and communications. Simultaneously, DAN should strive to strengthen capacities of current staff (at both the central and field levels) in nutrition and managerial operations (personnel, equipment, and inputs) for the Centre de Réhabilitation et d'Éducation Nutritionnelle (Recovery and Nutritional Education Center) (CREN), and for the Unité de Réhabilitation et d'Éducation Nutritionnelle (Recovery and Nutritional Education Unit) (UREN).

\section{DCMS}

The DCMS has a 16-officer staff including School Inspection and Information, Education, and Communication Officers, who work at the departmental level. However, only 5 of the 16 officers were found by this assessment to have the necessary qualifications. Based on interviews and the self-assessment data,

\section{RECOMMENDATIONS:}

- DCMS should redefine the profile of its officers to better match the Division's objectives and to strengthen capacities in nutrition. 
DCMS personnel appear to have few nutrition skills and are not motivated to implement nutrition activities in schools.

\section{MEPA and DAPSA}

At MEPA, the IOCA found an acute human resource gap. Efforts are ongoing to employ more staff; however, the assessment data indicate that only about 40 percent of existing vacancies would be filled by current recruitment endeavors. In addition, the staff is aging and some will need to be replaced.

At DAPSA, the majority of the statistics agency staff do not have basic training in statistical techniques for assessing food and nutrition security. As such, DAPSA is limited in its analytical capacity for nutrition.

\section{RECOMMENDATIONS:}

- MEPA should strengthen its field staff and advocate to the government for funds to reduce its human resource gap, including recruitment of a human resource manager and strengthening of nutrition staff.

- DAPSA should advocate to the government for funds to provide basic training in statistical assessment of food and nutrition security.

\section{Financial Management}

Financial resource management with respect to (1) financial planning, and (2) accountability and financial monitoring, is discussed below.

\section{Financial planning}

\section{BEN}

BEN's budget is created annually, in the last quarter of every year, within the framework of program and project planning. This system makes it difficult to take a long-term perspective and anticipate financial needs. Additionally, BEN budgets are prepared with little in-

formation regarding estimated funding. If substantial unplanned funding is received, the budget must be revised.

With respect to the BERs, BEN provides strategic direction and validates each $B E R$ budget during preparation of the Plan d'Action du Budget Annuel (Annual Budget Action Plan) (ABAP). BEN has acquired experience in financial planning and has been able to adapt its planning tool to attract as many partners as possible and, on the basis of the ABAP, adopt the disbursement schedule. However, the planning tool does not provide for multisector planning, which makes it challenging to plan with other sectors.

\section{DAN, DCMS, DAPSA, and MEPA}

These sectoral entities do not have financial management autonomy; their budget allocations are linked to those of their line ministries. Planning begins with the budget framework letter which sets priorities for the sector as a whole, with budgets generated from annual work plans (AWPs). As a result, funding for nutrion-sensitive activities within the Ministries of Health, Agriculture, and Education may be insufficient.

\section{RECOMMENDATIONS:}

- Under the PSMN, the CLM's budget planning tool must be reviewed so as to improve different sectors' contributions to nutrition budget planning for BERs.

- Heads of nutrition departments and divisions within line ministries and CLM focal points should continue to advocate to the relevant authorities to mainstream nutrition and to allocate sufficient resources to related activities.

- Improve the control of budgets assigned to state services. For example, the DCMS should advocate for the mainstreaming of nutrition indicators in the PAQUET-EF during the MEN's budget allocation review of program documents. 


\section{Accountability and financial monitoring}

\section{BEN}

Both the BEN and AECs are subject to financial management requirements that are highly systematized and based on clearly defined, published procedures designed to ensure financial accountability. Financial monitoring of the AECs is implemented by the BEN and conducted biquarterly by a fiduciary team, which uses TOMPRO accounting software in line with Système Comptable Ouest-Africain (West African Accounting System) (SYSCOA). The resulting Financial Progress Reports (FPR) are prepared and submitted every quarter to the CLM for approval. These FPRs are, in turn, used to ensure that audit reports are submitted within the timeframe set by national regulations and with partners.

With respect to procurement, BEN follows the national code set by the Public Procurement Regulating Authority (ARMP) as well as World Bank directives and donor procedures. Procurement is conducted at the central level; the BERs deal only with quotes from bidders.

\section{$D A N, D C M S, D A P S A$, and MEPA}

Overall, the DAN, DAPSA, DCMS, and MEPA fall under a public financial management system whose procedures are more rigid than rigorous, leading to poor resource optimization.

The 2014 DSRSE diagnostic report stresses that for implementation of the MSAS AWP, DAN generally lacks financial initiative. The report notes two shortcomings in the MSAS accounting system which contribute to this lack of initiative: (1) absence of an internal accounting information system; and (2) there is no distinction between state and TFP expenditures on interventions (DSRSE 2014).

DCMS prepares activity-based financial reports and an overall financial report. Audits are carried out only during the handing over of services with the assistance of an internal audit firm.

It is difficult to form a clear view of DAPSA's financial statements because only management reports are available.
MEPA's budget presentation and performance reports are prepared annually. Additionally, MEPA's General Administration and Equipment Directorate (DAGE) provides quarterly financial implementation reports based on a harmonized public finance management framework recently instituted by WAEMU.

\section{Program Management}

Program management was analyzed with respect to (1) planning; and (2) implementation and monitoring and assessment.

\section{Program planning}

Overall, planning by the units of analysis was found to be compartmentalized and characterized by minimal to no consultation with other nutrition sectors or actors other than those in direct partnership. Even if BEN coordinates its planning with other sectors, the IOCA found that those sectors were not actively involved "downstream" in nutrition-related activities.

\section{BEN}

The BEN has, since its inception, developed the strategic plans of CLM's flagship program, the PRN Indeed, BEN's program planning process is described in the implementation manual for PRN Phase II. ${ }^{5}$ This process is well-planned and implemented in a rigorous and systematic manner (figure 4). However, to date, BEN's planning process has not incorporated CLM programs other than the PRN, although efforts are now underway to strengthen CLM collaboration with other actors in the nutrition sector for the development of the PSMN. Regionally, the BERs take part in annual health sector planning and provide information on CLM support. Subregionally, planning meetings are held frequently by AECs.

DAN, DCMS, DAPSA, and MEPA

The IOCA found variable rates of nutrition-related program planning within the sectoral units of analysis. DAN's planning with other sectors and departments of the MSAS is historically poor. Recently however it has 


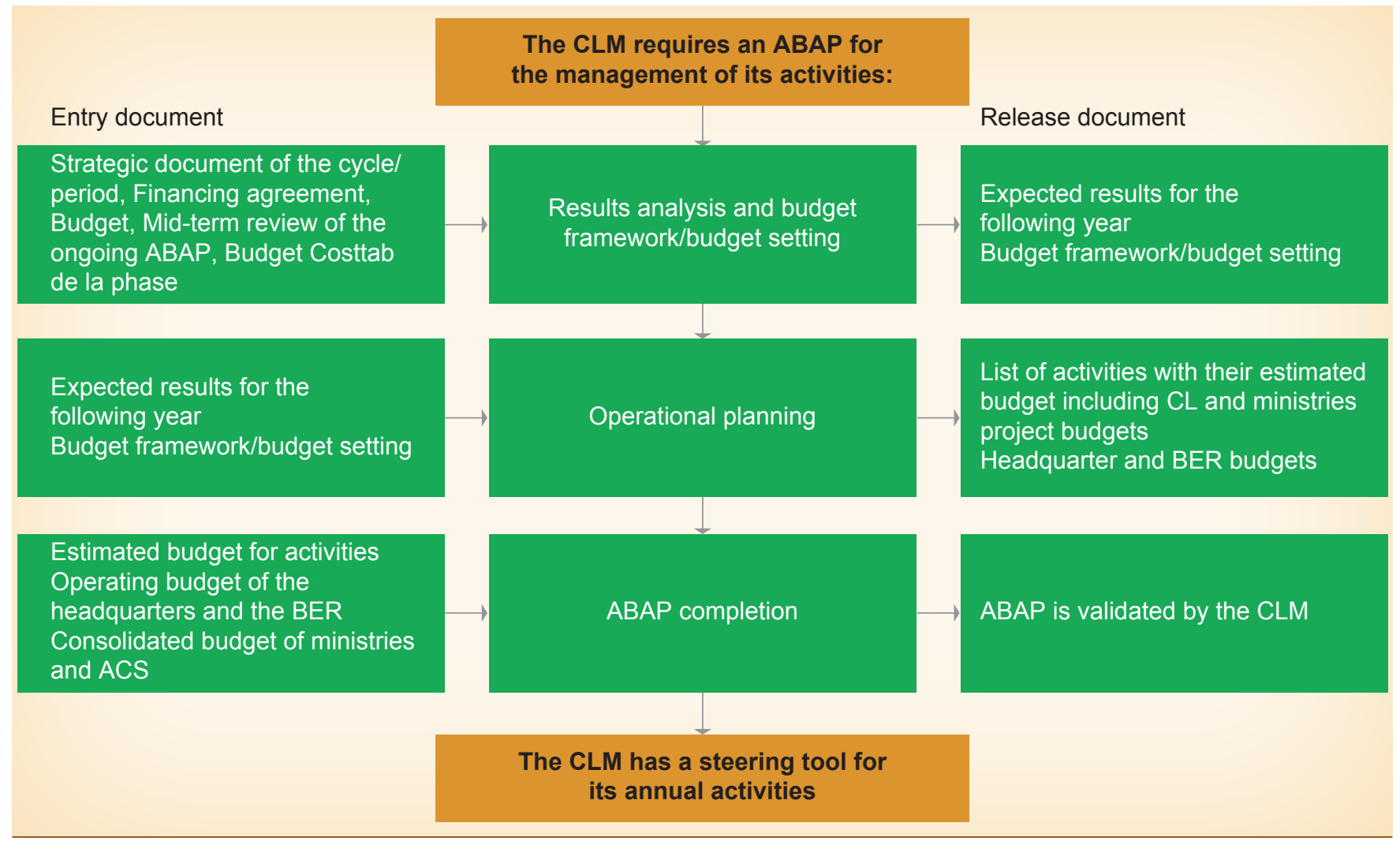

Source: CLM 2006.

started to involve other services and departments of the health sector in the development of its strategic plan.

DCMS has a nutrition policy document that spells out its strategic direction. In the 2013-25 PAQUET-EF of the education sector, integrated early childhood development (IECD) programs emphasize nutrition.

Nutrition-related planning is present in the DPPD and in the Programme in Support of the National Agricultural Investment Programme (PAP) of the MAER and MEPA. Specific agriculture-based projects aligned with the PNDN vision include the PASAV, RBF, the Programme Multinational de Renforcement de la Résilience à I'Insécurité Alimentaire et Nutritionnelle au Sahel (Multinational Programme for Food and Nutritional Resilience Building) (P2RS), and the Projet Intégré de Nutrition dans les Régions de Kolda et de Kédougou (Integrated Nutrition Project in Kolda and Kédégou Regions) (PINKK).
MEPA also conducts internal planning.

\section{RECOMMENDATIONS:}

Improving the planning process will strengthen the units of analysis' nutrition capacities:

- BEN should systematize budget orientation sessions for partners receiving CLM funding and involve the TFPs in the planning of BEN interventions.

- BEN should share with the BERs all information on agreements signed and commitments made with other sectors. BEN and BERs should set up formal frameworks to share and plan activities rather than relying on those carried out on an ad hoc basis.

- DCMS, DAPSA, MEPA, and DAN should expand their planning to other departments in their ministries and to partners to enhance synergies and build on experience. 
TABLE 6: BEN Monitoring System within the PRN Framework

\begin{tabular}{|c|c|c|c|}
\hline Level & Stakeholders & Reporting & Feedback \\
\hline \multirow[t]{3}{*}{ National } & BEN & \multirow[t]{3}{*}{ Data compilation 11 regions } & \multirow{3}{*}{$\begin{array}{l}\text { Performance analysis and } \\
\text { feedback to BERs and medical } \\
\text { regions }\end{array}$} \\
\hline & AEC & & \\
\hline & Ministry of Health departments & & \\
\hline \multirow[t]{3}{*}{ Regional } & BER & \multirow{3}{*}{$\begin{array}{l}\text { Compilation of data from } \\
\text { regional projects }\end{array}$} & \multirow{3}{*}{$\begin{array}{l}\text { Performance analysis and } \\
\text { feedback to BERs and health } \\
\text { districts }\end{array}$} \\
\hline & AEC & & \\
\hline & Medical regions & & \\
\hline \multirow[t]{3}{*}{ District } & Project manager & \multirow[t]{3}{*}{ Compilation of site data } & \multirow{3}{*}{$\begin{array}{l}\text { Performance analysis and } \\
\text { feedback to ARCs and health } \\
\text { centers }\end{array}$} \\
\hline & $A C$ & & \\
\hline & Health district & & \\
\hline \multirow[t]{3}{*}{ Site } & ARC & \multirow{3}{*}{$\begin{array}{l}\text { Data collection by ARC } \\
\text { Under the supervision of AC }\end{array}$} & \multirow{3}{*}{$\begin{array}{l}\text { Performance analysis and } \\
\text { feedback information to the } \\
\text { community (community return) }\end{array}$} \\
\hline & Steering committee & & \\
\hline & Beneficiaries & & \\
\hline
\end{tabular}

Source: CLM 2006.

\section{Program implementation and monitoring and assessment}

\section{BEN}

Various projects and programs are implemented by BEN as mentioned above. They are mostly implemented through partners, including 18 AECs, this report's units of analysis and other sectoral entitites, as well as the private sector (oil mills, flour mills, and salt producers).

In addition to its role as funder, BEN is the final destination for data which are collected, compiled, and assessed each month, as part of a monitoring system stipulated in the PRN (table 6). This system is ongoing and is used by supervisors to ensure continuous improvement in the quality of program services. The following indicators are used to assess AEC performance at individual implementation sites:

- Percentage of children weighed

- Percentage of malnourished children

- Percentage of children having gained weight

- Number of talks delivered

- Attendance at talks
- Percentage of children age 6-59 months receiving vitamin A supplementation

- Percentage of dewormed children age 6-59 months

Overall, these indictators are primarily output (as opposed to impact) oriented.

In addition to routine data collection, quarterly monitoring visits are organized by BEN in addition to those conducted by the BERs. At least once a year, a field visit is organized by the CLM to evaluate the implementation of each program.

\section{DAN, DCMS, DAPSA, and MEPA}

In addition to DAN's interventions in the area of nutrition and the MSAS nutrition programs, CLM funds specific nutrition activities for DAN to conduct vitamin A supplementation and child survival days. Many of these include screening for malnutrition, promotion of EBF, nutrition education, and catch-up vaccinations. With respect to monitoring and assessment, DAN uses the District Health Information System (DHIS2). This internationally recognized software platform includes data collection tools for weekly monitoring and sentinel site surveillance, as well as a dashboard for performance 
indicators. The system is hosted by the DSRSE and takes the DAN nutrition indicators into account. At regional and district levels, health staff are dedicated to monitoring and assessment but nutrition is not sufficiently addressed.

DCMS implements nutrition-related activities in four regions and targets trainees between 7 and 14 years old. These interventions focus on the promotion of salt consumption in schools, iron supplementation and deworming, development and integration of nutrition in the curriculum, teaching aids for nutrition, training of teachers, and monitoring of activities. Although a monitoring and assessment system has been established for DCMS within the PAQUET-EF framework, its indicators are not included in the MEN Performance Measurement Framework. That said, MEN performance indicators do include the number of children receiving iron supplements and deworming treatment, as part of the Conseil Communautaire de Développement Intégré de la Petite Enfance (Community Council for Integrated Early Childhood Development).

DAPSA and MEPA carry out interventions through their decentralized services. Several potentially nutrition-sensitive projects and programs are implemented by these two entities, with emphasis placed on food security and increased production. Additional activities are undertaken in partnership with CLM within the framework of PASAV. However, agriculture field staff is often unaware of agreements between their line ministry and CLM. At the time this study was conducted, DAPSA did not have a monitoring system but did conduct ad hoc data gathering; MEPA was constructing a system, including a data gathering mechanism, an outcome measurement framework, and identification of stakeholders.

\section{Intra- and Interorganizational Relations}

Intra- and interorganizational relations were assessed along three dimensions: (1) external communication, (2) intrasectoral collaboration, and (3) intersectoral collaboration.

\section{RECOMMENDATIONS:}

- BEN should use monitoring and assessment software to improve its data presentation.

- To avoid duplication of effort in health districts, BEN and DAN should harmonize indicators and data gathering tools to facilitate the work of health personnel and improve the use of community data by health facilities.

- BEN should evaluate impact as well as/instead of outcome indicators and disseminate the assessment results.

- DAN should, in cooperation with other stakeholders, focus on improving the monitoring and assessment of nutrition indicators at the region and district levels.

- DCMS and DAPSA should each set up a monitoring and assessment system in line with the PMSN.

- All units of analysis should focus on staff training in monitoring and assessment.

- Efforts should be made to create mechanisms for data and information sharing between the units of analysis.

\section{External communication}

\section{BEN}

The BEN's external communications include annual reports (disseminated to the general public as well as to nutrition stakeholders), and campaigns and exhibitions promoting general nutrition information as well as iodization, fortification, and PASAV. Dissemination channels include radio, television and posters. BEN also holds press briefings at the end of workshops to help publicize CLM actions and may distribute workshop reports and documents to stakeholders.

For the CLM and donors, BEN produces quarterly FPRs to help ensure alignment with the ABAPs.

At BER level, information is shared during CRS and Comité Régional de Coordination et de Contrôle de l'iodation du sel (Regional Coordination Committee for Salt lodization Control) (CRCCIS) meetings, quarterly and annual reviews with local councils, and field vis- 
its. AECs organize radio programs and participate in interviews

Notably, the CLM's website provides basic information on the CLM, its programs, its areas of intervention, and its TFPs, but it has not been updated.

\section{$D A N, D C M S, D A P S A$, and MEPA}

DAN uses MSAS staff meetings to share information at the ministry level, and organizes symposiums, shows, and forums for the general public. DCMS does not always communicate on its interventions, but it shares reports on its key activities with the MEN. Neither DAPSA nor MEPA communicate to the general public regarding activities; both have, however, updated websites that contain extensive information on its interventions.

\section{RECOMMENDATIONS:}

- BEN and the CLM should develop a digital communication strategy that updates their websites and raises nutrition sector visibility; sector visibility should also be increased through advertisements, television documentaries, and press packs.

- BEN and BERs should increase visibility at the regional level through radio programs on nutrition.

- "Nutrition tours" with the regional, national, and international media and open house events would increase the public's awareness of nutrition issues.

- DCMS should improve its visibility by promoting its health and nutrition activities and by better engaging the Direction de la Planification et de la Réforme de l'Éducation (Department of Educational Planning and Reform) (DPRE) and communicating with other MEN divisions and departments.DAN should improve its visibility by implementing its media communication plan and by working in close collaboration with DSRSE's communication unit and Service National de l'Éducation et de l'Information pour la Santé (National Service for Education and Information on Health) (SNEIPS). DAN and the CLM should also work together to develop the capacities of health journalists.

\section{Intrasectoral collaboration}

The IOCA found intrasectoral collaboration to be a challenge in all the sectoral units of analysis. CLM sectoral focal points were unable to exert influence within their ministries, and the dissemination of information on nutrition and CLM actions was poor, constraining vertical action within sectors.

\section{Intersectoral collaboration}

Intersectoral coordination is important because it improves sectoral accountability and coherence in the definition and implementation of nutrition interventions. Three aspects of intersectoral collaboration are discussed below: (1) collaboration between nutrition stakeholders from different sectors; (2) collaboration between the CLM and nutrition stakeholders; and (3) collaboration between donors.

\section{Collaboration between nutrition stakeholders}

BEN has developed relationships with various nutrition stakeholders for the implementation of PRN and other projects. The bulk of these relationships are contractual; BEN, through CLM, provides funding to nutrition-specific or nutrition-sensitive interventions implemented by the various sectors. Thus, BEN works closely with actors from health, education, agriculture, trade, and finance as well as CLs and AECs, the private sector (oil processors, flour mills, and salt producing units), and research.

At the regional level, the BERs collaborate through the administrative authorities with all the decentralized bodies as part of PRN.

While collaboration was found by the IOCA to be weakest at the district level due to poor command of nutrition issues and lack of essential services, inadequate coordination in the sector surfaced as a leitmotiv at all levels. For example, CRSs and Comités départemental de suivi (Departmental Follow-up Committees) (CDSs), which coordinate key services of the nutrition sector around the administrative authorities at the regional level, are rigid and hamstrung by bureaucratic 
formalities that discourage close collaboration between stakeholders from different sectors.

\section{Collaboration between the CLM and sectoral stakeholders}

Response data from the online survey conducted by the IOCA indicate that sector-based nutrition stakeholders consider collaboration with the CLM to be strong with respect to policy development and strategic planning. Opinions were mixed regarding technical collaboration, and most stakeholders believed that collaboration between sectoral actors and the CLM is lacking in terms of monitoring and assessment and financial issues.

The latter is of particular note given that a key aspect of collaboration between the CLM and sector-based stakeholders is based on funding for the PRN and other projects managed by CLM through memorandums of understanding signed with AECs, communes, and the education, health, trade, livestock breeding, agriculture, industry, and research sectors. In this regard, CLM is considered a provider of funds for implementation of the PRN and other programs. This characterization-that the CLM's mission is merely implementation of the PRN-includes the perception that the BEN's strong focus on PRN implementation has been detrimental to the CLM's other functions, including activities promoting multisectoral collaboration. However, it is important to note that the PRN itself creates a solid foundation for multisectoral action.

That said, it has been difficult to institutionalize nutrition across sectors. The CLM works closely across line ministries through focal points appointed by the Prime Minister in an order dated March 27, 2003. In principle, these focal points are meant to function not only as intermediaries between the CLM and their respective sectors, but also as nutrition champions. However, very few of these individuals play this role in practice, as typically they do not occupy a strategic position in their ministries and have little influence. Additionally, the IOCA documented specific challenges regarding the mission of two key sectoral entities-MSAS and the Conseil National sur la Sécurité Alimentaire
(National Food Security Council) (CNSA)—relative to that of the CLM:

- Historically, MSAS considered nutrition within its purview because of its clinical aspect. With the establishment of the CLM, there was a perception that this responsibility had been usurped. In addition, the health sector has found it difficult to adapt to the multisectoral paradigm for nutrition. Although improvement has been made over time, collaboration is not as yet optimal; clarification of the roles and responsibilities played by the health sector at the central and subnational levels is needed.

- The CNSA is responsible for monitoring the implementation of food safety policies and programs and has received training from the CLM on nutrition, including SMART Survey methodology. Conversely, the CLM is a member of the Consultation Council and Working Group of the System d'Alerte Précoce (Early Warning System), both of which were established by the CNSA. Despite these and related efforts, challenges remain to

\section{RECOMMENDATIONS:}

- The CLM should revise the terms of reference of its members, clearly defining their roles in relation to their respective sectors, other CLM members, and the CLM itself.

- The CLM should raise the profile of its sectoral focal points and facilitate their roles as nutrition champions, coaching them to use their sector-specific expertise to identify strategies to institutionalize nutrition, and by placing appropriate communication tools at their disposal.

- The CLM must affirm its leadership in the field of nutrition and strengthen its strategic dialogue and advocacy with various sectors for the institutionalization of nutrition. It must also address its intersectoral coordination mission by creating a multisector platform that coordinates all stakeholders, meets regularly, and conducts joint monitoring actions. Such efforts would clarify roles and responsibilities and facilitate establishment of a common performance measurement framework such as sectoral reviews. 
fostering synergies between food security and nutrition interventions for harmonization of actions, joint planning and monitoring, and overall willingness to collaborate.

\section{Collaboration among donors}

As with other nutrition stakeholders, the IOCA found the culture of collaboration to be poor among donors. Three main challenges were identified:

- Lack of nutrition skills; some TFPs have weak skills in nutrition, which constrains their understanding of the issues and their engagement in the sector.

- Limited participation of some TFPs in multisectoral development efforts, nutrition and otherwise.
- Challenges inherent to the organizations themselves; planning cycles, strategic priorities, and resource constraints all affect an organization's capacity to collaborate with others; interagency competition for financial resources also hinders collaborative work.

It is important to note that these findings were offset by additional data indicating that recent progress has been made due to increased emphasis on joint development of policies and programs. Cases of joint funding and joint implementation of nutrition programs were also identified, for example, the pooling of REACH, Bureau d'appui à section coopération de l'Ambassade du Canada au Sénégal (Program Support Unit to the Development Program of the Embassy

TABLE 7: Access to Technology and Infrastructure-BEN, BER (Thiès), DAPSA, DAN, and DCMS

\begin{tabular}{|c|c|c|}
\hline \multirow[t]{2}{*}{ Unit of analysis } & \multicolumn{2}{|c|}{ Technological means and infrastructure } \\
\hline & Availability & Limitations \\
\hline BEN & $\begin{array}{l}\text { Technology } \\
\text { - Server and sound Internet connectivity } \\
\text { - Intranet } \\
\text { - Computer hardware } \\
\text { - Telephone line } \\
\text { - SYSCOA } \\
\text { - Backup system for financial data } \\
\text { Infrastructure } \\
\text { - Proper location of office } \\
\text { - Office space occupied }\end{array}$ & $\begin{array}{l}\text { - Limited capacity of server } \\
\text { - CLM website not regularly updated } \\
\text { - Intranet limited to the head office with reduced } \\
\text { functionality } \\
\text { - Data protection (antivirus and data backup) not } \\
\text { systematically assured; only financial data are } \\
\text { automatically backed up } \\
\text { - Software obsolete and replacement of computer } \\
\text { - hardware not systematic } \\
\text { increasingly confined and meeting room cramped }\end{array}$ \\
\hline BER (Thiès) & $\begin{array}{l}\text { Technology } \\
\text { - Telephone and Internet } \\
\text { - Computer hardware } \\
\text { Infrastructure } \\
\text { - Proper location of office }\end{array}$ & $\begin{array}{l}\text { - Telephone exchange dilapidated; limited service } \\
\text { reduces communication with AECs and partners } \\
\text { - Low Internet capacity with an outdated system } \\
\text { - Poor waterproofing of the building and insufficient } \\
\text { number of toilets }\end{array}$ \\
\hline DAPSA & $\begin{array}{l}\text { Technology } \\
\text { - Acquisition of resource center and tablets for } \\
\text { surveys } \\
\text { Infrastructure } \\
\text { - Proper location of office }\end{array}$ & $\begin{array}{l}\text { - Offices congested at central and decentralized } \\
\text { levels }\end{array}$ \\
\hline DAN & $\begin{array}{l}\text { Technology } \\
\text { - Computer hardware } \\
\text { - Interphone and telephone } \\
\text { Infrastructure } \\
\text { - Offices in good shape and operational at } \\
\text { central level }\end{array}$ & $\begin{array}{l}\text { - Staff pay for calls } \\
\text { - Limited access to Internet during field missions } \\
\text { - Sustainability issues because rent is dependent on } \\
\text { contributions of TFPs } \\
\text { - Low availability of SAM units at field level }\end{array}$ \\
\hline DCMS & $\begin{array}{l}\text { Infrastructure } \\
\text { - Proper location of offices } \\
\text { - Dependence on Cheikh Anta Diop University }\end{array}$ & $\begin{array}{l}\text { - Exposure to vandalism from recurrent strikes } \\
\text { - Faulty electrical installations in the offices cause } \\
\text { frequent power outages; quotes for repairs are } \\
\text { prohibitive }\end{array}$ \\
\hline
\end{tabular}




\section{RECOMMENDATIONS:}

- Providing a structure for TFP collaboration on nutrition (and other types of initiaves) will increase the consistency of their actions. Such a structure should be informed by sectoral reviews, which foster accountability and improve complementarity between programs.

- Within the nutrition sector, development of the PSMN increases the need to strengthen collaboration among TFPs. Pooled funding targeting common priorities must be established.

\section{RECOMMENDATIONS:}

- BEN should regularly take stock of its computer resources and infrastructure to establish needs and requirements.

- Units of the various ministries should give priority to the preventive maintenance of computer hardware rather than addressing problems as they appear or upon demand.

- Special attention should be paid by each unit to the need for functioning workspaces at the central and regional levels. of Canada to Senegal) (BACDI), UNICEF, and World Bank resources to back CLM efforts. The United Nations platform was identified as one of the most important in the nutrition sector, having facilitated the development and dissemination of a technically correct nutrition paradigm, and for providing a forum for discussion of nutrition goals and priorities.

\section{Technology and Infrastructure}

Access to technology (hardware and software), a functional office space, and basic infrastructure are baseline requirements for institutional and organizational capacity. Table 7 provides details on these fundamentals for five of the IOCA's units of analysis. Overall, although these institutions remain functional, each unit faces specific technological and infrastructure challenges that require targeted solutions. 


\section{Organizational Culture and Incentives within the Units of Analysis}

\section{KEY POINTS}

- Despite a strong organizational culture at the CLM and high morale at the BEN, staff at all units of analysis are hindered by problems of human resources and insufficient knowledge of the real value and mission of their respective institutions.
- Overall, incentives are weak, as both financial and nonpecuniary compensation are inadequate.

- Each entity must find innovative methods to motivate their staffs and boost their morale, both at the central and decentralized levels.

\section{Organizational Culture}

Nine basic values (figure 5) inform the organizational culture of the CLM. Two notable examples of how these values are realized in day-to-day operations are the sharing of technical and financial documents, and the fact that the same per diem allowance is granted to all personnel during missions.

The IOCA noted demonstrated commitment by BEN staff (at the head office and at the regional office of Thiès) to these core values. Personnel described their working environment as promoting freedom of participation, a sense of responsibility, continuous learning, team spirit, and diversity. In many cases, staff go above and beyond by working overtime and being unusually flexible.
However, a history of some staff, primarily administrative personnel, being less embracing of these core values was also noted, with many such individuals leaving the agency altogether.

BEN's main challenge lies primarily in the systematic dissemination and promotion of its values internally and to new staff. In particular, current staff should communicate their commitment to the organization's values to new staff.

\section{Incentives}

As incentives are an important pillar of organizational motivation, the IOCA assessed whether the units of 


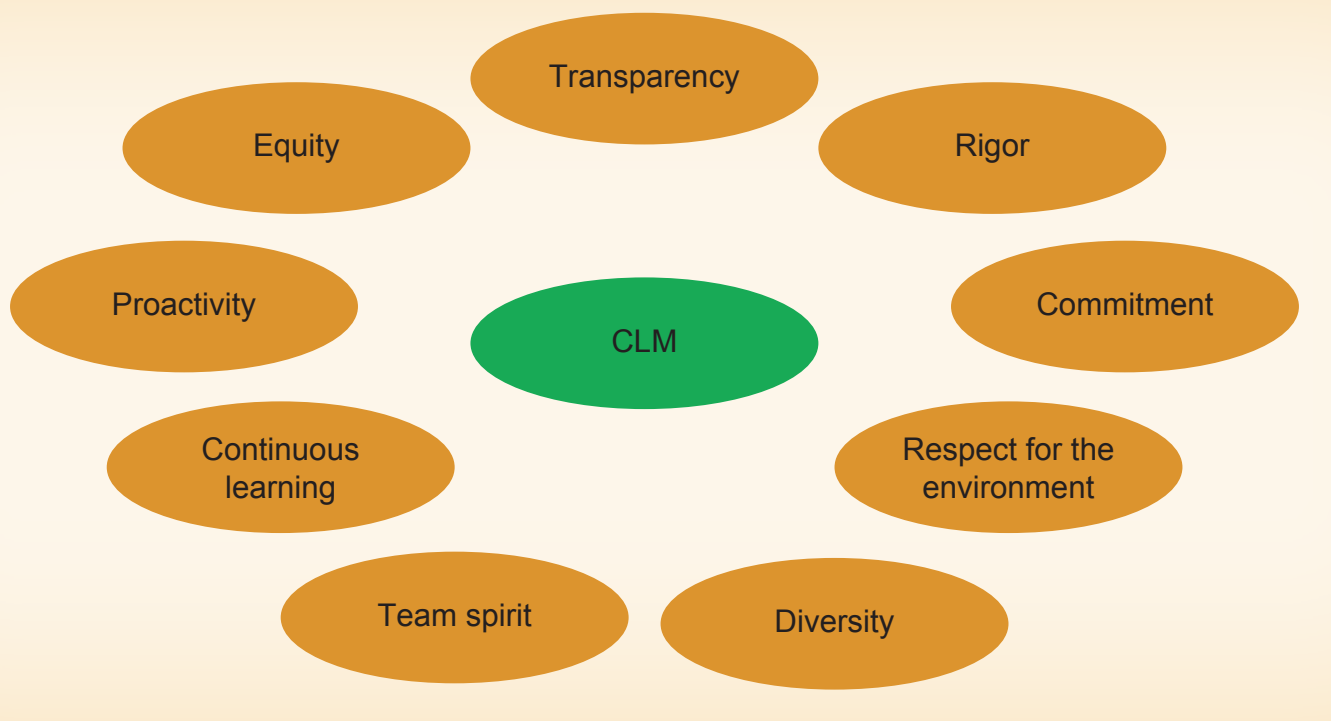

Source: CLM undated.

analysis had incentive systems in place to (1) encourage performance; (2) provide adequate compensation; (3) provide nonpecuniary incentives; and (4) improve staff morale.

\section{Incentives to encourage performance}

Although contracts are regularly renwewed, many BEN staff hold the status of service providers or consultants, with consequent restricted career opportunities and reduced job security.

Additionally, although BEN has an annual performance review system through which salary increases are determined, pay increases depend on the availability of financial resources. Further, although rewards to outstanding staff had historically been made annually, this practice has disappeared in recent years.

As ministerial entitites, DAPSA, DCMS, DAN and MEPA are subject to the Civil Service Code. However, staff at each of these units of analysis complained about a weak incentive system that does not encourage performance. Additionally, it was noted that overtime is not paid when it is due. At MEPA specifically, the efforts of a trade union to introduce risk-based bonuses have been in vain, and salaries and benefits were noted to be meager despite staff reports of being proud of the work and the studies undertaken.

\section{Adequate compensation}

The IOCA concluded that salaries at the BEN do not match workload, and while staff at the Thiès BER reported feeling well rewarded, ministerial entity staff did not.

\section{Existence of nonpecuniary incentives}

The BEN's nonfinancial benefits are traditional: medical insurance (depending on the availability of financial resources) and pensions. There are also professional training opportunities. In the sectoral services, nonfinancial benefits include awards, medical insurance, pensions, paid leaves of absence, and family allowances.

\section{Staff morale}

Mixed responses were received concerning staff morale. According to BEN and BER staff, morale is good overall, because many perceive the work as a vocation. At CLM, morale is considered good although there 
were complaints about staff incentives, which have yet to be solved. At DCMS, morale is good on the whole. At DAN, excessive workload and requests for meetings create scheduling conflicts and hamstring the limited number of qualified staff. This challenge was cited as a source of frustration affecting staff morale. At MEPA, morale was reported to be very low, as evidenced by requests for redeployment to other ministries.

\section{RECOMMENDATIONS:}

- The BEN should improve the control and visibility of financial resources to improve performance by urging TFPs to consider staff motivation in the provision of funding.

- The BEN's employee recognition activities should be restored, for example, merit or seniority-based staff awards, letters of congratulation, certifications, and an annual staff celebration event.

- The CLM should improve its reimbursement of work-related expenses, such as transportation costs, currently paid by staff.

- Ministerial entities should raise salaries, improve the timeliness of overtime renumeration, grant performance-based bonuses, and introduce risk bonuses when appropriate.

- Staff enrichment activities within the BEN and BERs should be introduced, for example, study trip and training opportunities.
- BER officials should be permitted to use corporate vehicles for professional purposes, including after regular working hours when necessary, amending the manual of procedures if necessary.

- To boost staff morale, the BEN and BERs should create opportunities for socialization.

- To enhance its attractiveness, MEPA should improve working conditions and increase salaries and benefits.

- DCMS should enhance staff motivation measures by strengthening capacity and increasing allowances.

- DAN should improve its working environment by creating opportunities for socialization and equipping the division with basic amenities. 


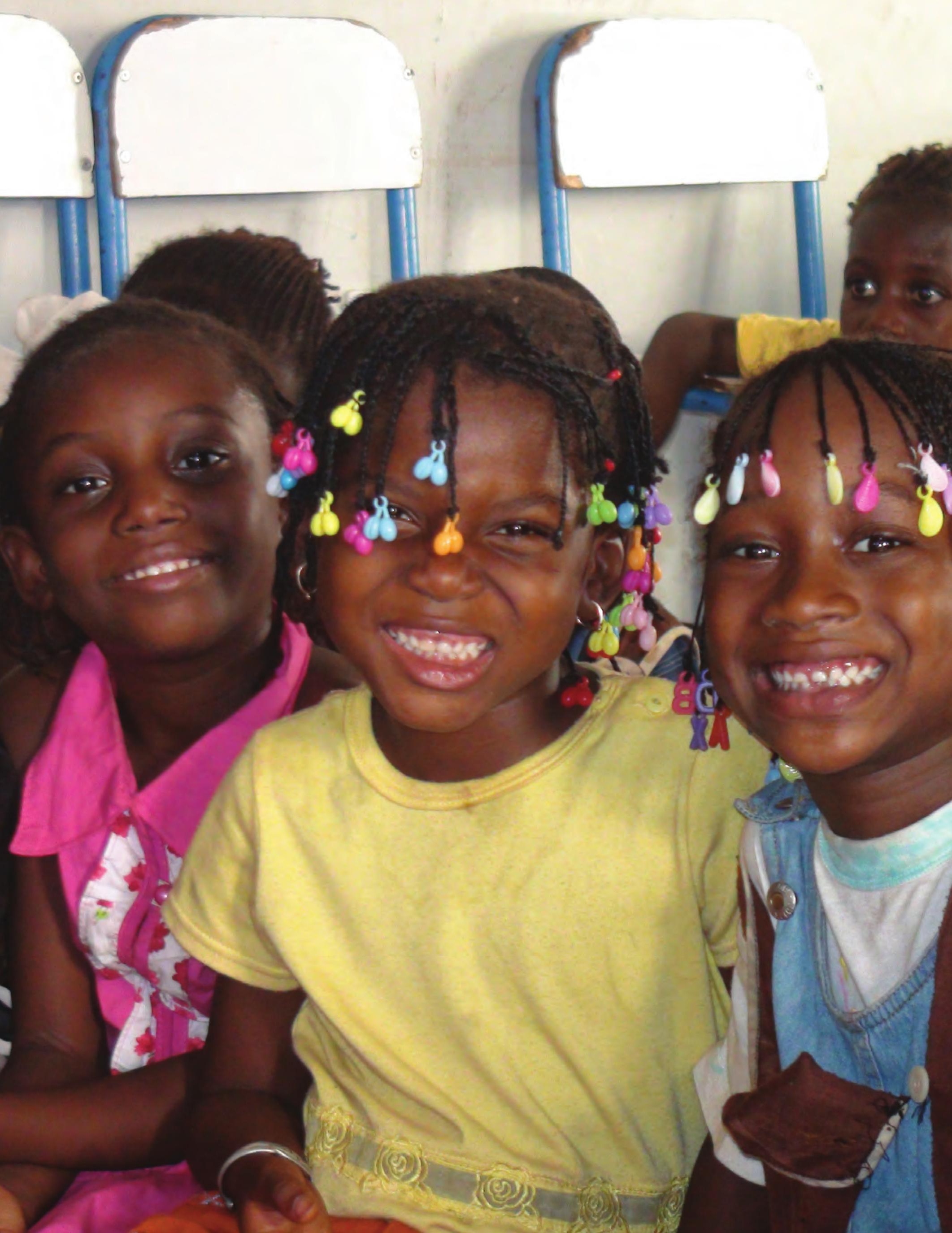




\section{Organizational Performance of the Units of Analysis}

\section{KEY POINTS}

- The results for the various units on the four areas of performance (efficiency, effectiveness, relevance, and financial sustainability) fluctuate. The overall score is average, with efficiency the highest at 70 percent and financial sustainability the lowest at 57 percent.

- The analysis of CLM and BEN's mission highlighted the fundamental issue of responsibility for implementation. BEN's mission should be strengthened to reflect the evolution of the context of nutrition and current knowledge and risks.

- According to stakeholders of the units of analysis, effectiveness is achieved through sacrifice and long working hours by the personnel of the various institutions.
- The nutrition sector and CLM must adapt to the changing context of nutrition to remain relevant. Multisectorality, collaboration and coordination of the stakeholders, the mainstreaming of nutrition by line ministries as reflected in substantial budget allocations, the endowment of qualified human resources, the integration of objectives and alignment of policies are areas of nutrition governance that CLM and BEN must address.

- Financial sustainability of the nutrition sector suffers from its dependence on foreign funding despite the efforts of the government.

- The units of analysis have diversified their sources of funding through multiple partnerships.
This section of the IOCA was based on four criteria:

- Efficiency: Extent to which a unit of analysis is capable of meeting its goals.

- Effectiveness: The ratio between the results and the financial resources spent to attain those results.

- Relevance: Ability of an organization to meet the needs of priority stakeholders and secure their support in the short and long term.
- Financial viability: The ability of an organization to secure the necessary financial resources to meet its functional requirements in the short, medium, and long term.

As described in section 1 of this report, each of these criteria was assigned a set of indicators, with each indicator receiving a quantitative score between 0 and 5 , as well as a qualitative component. Based on these 
individual indicator scores, each criterion received an average score (calculated by averaging the scores of the individual indicators). Expressed as a percentage, these summary scores are rated "Strong", "Average", or "Poor" (see table 2).

As shown in figure 6 , results varied widely between different units of analysis. The BEN scored over 70 percent across all four dimensions, including "strong" scores of over 80 percent for efficiency and effectiveness. DAN scored 80 percent for relevance but 60 percent for effectiveness and financial viability, MEPA scored between approximately 50 and 70 percent on all indicators, and DAPSA received "poor" scores (under 50 percent) across the board, in part because it does not implement programs.

Mean scores were also calculated for each of the four criteria, providing a rough estimate of the average performance for all five units of analysis. For these mean scores, effectiveness was highest (70 percent), financial viability was lowest (57 percent), and efficiency and relevance were just over 60 percent.

A qualitative analysis was conducted in tandem with the IOCA tool quantitative assessment. Selected findings from this qualitative component are discussed below.

\section{Efficiency}

Efficiency was assessed based on goal attainment by the CLM and the BEN and beneficiary satisfaction.

\section{Attainment of mission or goals}

Attainment by the CLM and BEN of goals set by their constituent decrees and orders was found to be mixed. Table 8 summarizes results based on interviews with BEN and CLM staff, TFPs, and sector-based nutrition stakeholders.

$B E N$ reports on 13 specific nutrition outcome and process indicators as part of its PRN mandate. Although a few, such as oil fortification and salt iodization, remain below target levels, overall the data indicate that the program is on track and in some cases exceeding set goals (figure 7).

Due to IOCA logistical constraints, no qualitative data were collected for the other units of analysis regarding attainment of goals. However, it is important to note that for the agricultural and livestock sector, targets are set annually and relate to increased production. In this sector, climate hazards pose a major risk and require proactive and appropriate mitigation strategies.

FIGURE 6: Comparative Organizational Performance between Units of Analysis

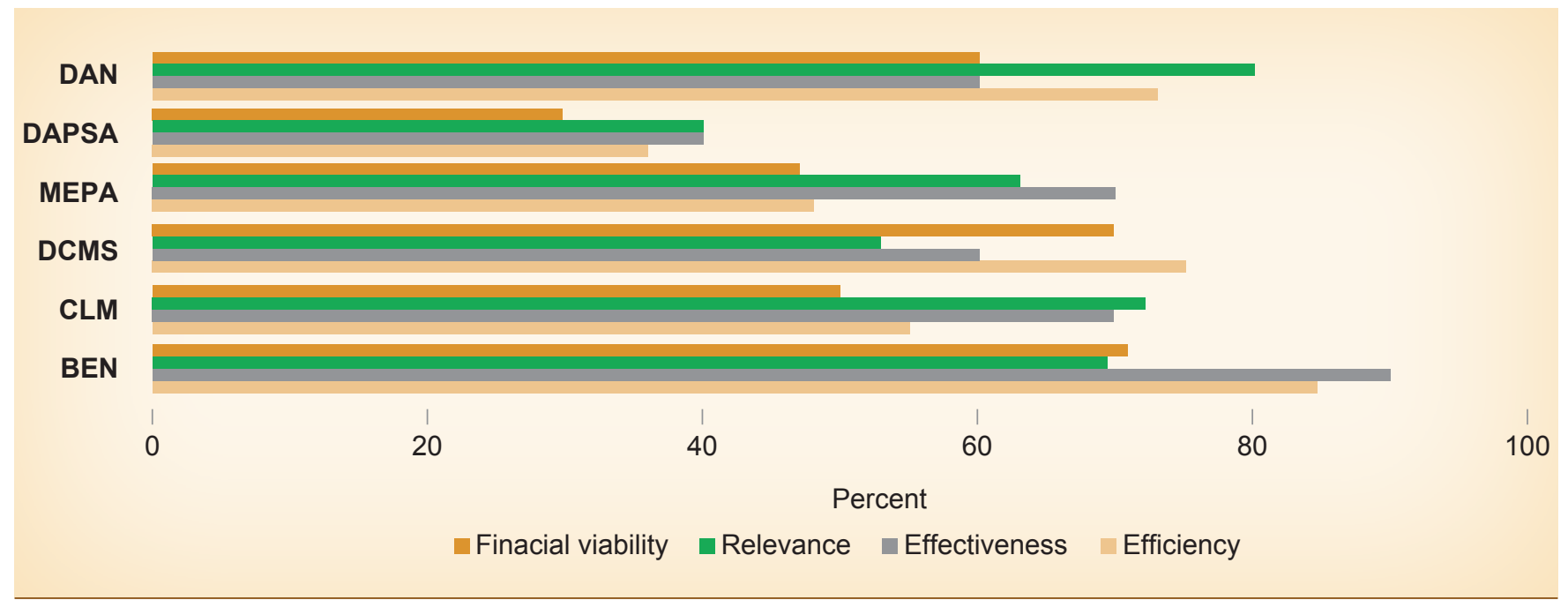

Source: IOCA data. 


\begin{tabular}{|c|c|c|}
\hline Mission & $\begin{array}{c}\text { Efficiency } \\
\text { (Attainment of mission) }\end{array}$ & Comments \\
\hline \multicolumn{3}{|l|}{ CLM } \\
\hline $\begin{array}{l}\text { Ensure efficiency of the } \\
\text { commitments made under the } \\
\text { LPDN }\end{array}$ & Very satisfactory & $\begin{array}{l}\text { The policy documents that refer to these } \\
\text { commitments are updated regularly by the } \\
\text { CLM }(2001,2006,2015) \text { and explicitly support } \\
\text { implementation by the BEN. }\end{array}$ \\
\hline $\begin{array}{l}\text { Establish a consultation } \\
\text { framework that includes } \\
\text { ministries, CLs, NGOs and CBOs }\end{array}$ & & $\begin{array}{l}\text { There is no formal multistakeholder consultation } \\
\text { framework. However, stakeholders are regularly invited } \\
\text { to and participate in CLM meetings, and a collaborative } \\
\text { with CLs has been established. Some Regional } \\
\text { Monitoring Committees have also been established. }\end{array}$ \\
\hline $\begin{array}{l}\text { Develop synergies with other } \\
\text { poverty reduction programs }\end{array}$ & & $\begin{array}{l}\text { The LPDN and and PNDN are aligned with the DSRP } \\
\text { and the PSE. }\end{array}$ \\
\hline $\begin{array}{l}\text { Foster the development of national } \\
\text { capacities in nutrition }\end{array}$ & Satisfactory & $\begin{array}{l}\text { Overall, there is a lack of nutritionists; no nutritionists } \\
\text { were working at the BEN at the time of the study. } \\
\text { However, links have been made with the SUN } \\
\text { Movement, which supports nutrition governance. } \\
\text { Links have also been established with the Nutrition } \\
\text { Laboratory of UCAD, although interviewees noted this } \\
\text { connection was weak. }\end{array}$ \\
\hline $\begin{array}{l}\text { Promote a policy of IEC on } \\
\text { nutrition }\end{array}$ & & $\begin{array}{l}\text { BCC strategies are well established, although the } \\
\text { challenge of coordinating with other stakeholders } \\
\text { remains. }\end{array}$ \\
\hline $\begin{array}{l}\text { Collect the activity reports of CLs, } \\
\text { public services, NGOs, and CBOs }\end{array}$ & & $\begin{array}{l}\text { The CLM does not systematically report on ministries, } \\
\text { CLs, or NGOs that have not secured funding from the } \\
\text { CLM or TFPs. }\end{array}$ \\
\hline $\begin{array}{l}\text { Portray the nutritional situation } \\
\text { nationwide through the use of an } \\
\text { efficient information system }\end{array}$ & Not satisfactory & There is no nationwide information system. \\
\hline $\begin{array}{l}\text { Draft an annual report on } \\
\text { malnutrition control policies }\end{array}$ & & $\begin{array}{l}\text { There is no annual report on malnutrition control } \\
\text { policies. }\end{array}$ \\
\hline \multicolumn{3}{|r|}{ P } \\
\hline $\begin{array}{l}\text { Develop and submit to the CLM an } \\
\text { annual work plan and a budget }\end{array}$ & & $\begin{array}{l}\text { BEN AWPs and budgets are systematically presented } \\
\text { to the CLM at the beginning of every year. }\end{array}$ \\
\hline Draft a Manual of Procedures & & $\begin{array}{l}\text { A Manual of Procedures has been drafted and is } \\
\text { regularly updated. }\end{array}$ \\
\hline $\begin{array}{l}\text { Ensure the efficient and effective } \\
\text { execution of the budget allotted to } \\
\text { PRN }\end{array}$ & & A thorough management system is in place. \\
\hline $\begin{array}{l}\text { Prepare tendering packages } \\
\text { related to activities of the PRN } \\
\text { according to statutory provisions }\end{array}$ & & $\begin{array}{l}\text { Some procurement and recruitment procedures are in } \\
\text { place and systematically followed. }\end{array}$ \\
\hline $\begin{array}{l}\text { Participate in the design and } \\
\text { implementation of nutrition } \\
\text { projects }\end{array}$ & Very satisfactory & $\begin{array}{l}\text { The BEN has developed and implemented several } \\
\text { nutrition projects and programs. }\end{array}$ \\
\hline $\begin{array}{l}\text { Propose studies of how to improve } \\
\text { the population's nutritional } \\
\text { situation }\end{array}$ & & $\begin{array}{l}\text { The BEN has conducted the following landmark } \\
\text { studies: PRN Impact Study (2004-06); Knowledge- } \\
\text { Practices-Coverage Study (approximately 2005); } \\
\text { a beneficiaries' satisfaction survey (approximately } \\
\text { 2005); and an assessment of NETS in } 2012 . \\
\text { However, results have not been effectively } \\
\text { disseminated. }\end{array}$ \\
\hline $\begin{array}{l}\text { Review the financial and } \\
\text { accounting situation on an annual } \\
\text { basis }\end{array}$ & & Financial reports are drafted quarterly and annually. \\
\hline $\begin{array}{l}\text { Draft quarterly and annual activity } \\
\text { reports }\end{array}$ & & $\begin{array}{l}\text { Quarterly and annual activity reports are } \\
\text { systematically drafted. }\end{array}$ \\
\hline
\end{tabular}


TABLE 8: Assessment of Attainment of Mission: CLM and BEN (continued)

\begin{tabular}{|c|c|c|}
\hline Mission & $\begin{array}{c}\text { Efficiency } \\
\text { (Attainment of mission) }\end{array}$ & Comments \\
\hline $\begin{array}{l}\text { Prepare reviews of the PRN } \\
\text { scheduled under the program's } \\
\text { Credit Agreements }\end{array}$ & Satisfactory & $\begin{array}{l}\text { These reviews are prepared but are not open to } \\
\text { stakeholders of the sector, including TFPs. }\end{array}$ \\
\hline $\begin{array}{l}\text { Create, manage, and update a } \\
\text { nutritional information system and } \\
\text { make it accessible }\end{array}$ & Not satisfactory & $\begin{array}{l}\text { Although the BEN has an internal information system } \\
\text { tracking implementation of various projects, there is } \\
\text { no sector-wide mechanism for sharing information } \\
\text { that is easily accessed by multiple stakeholders. }\end{array}$ \\
\hline
\end{tabular}

Note: See Acronym List for full names of organizations.

FIGURE 7: BEN-CLM Results for Selected Indicators, 2009-14

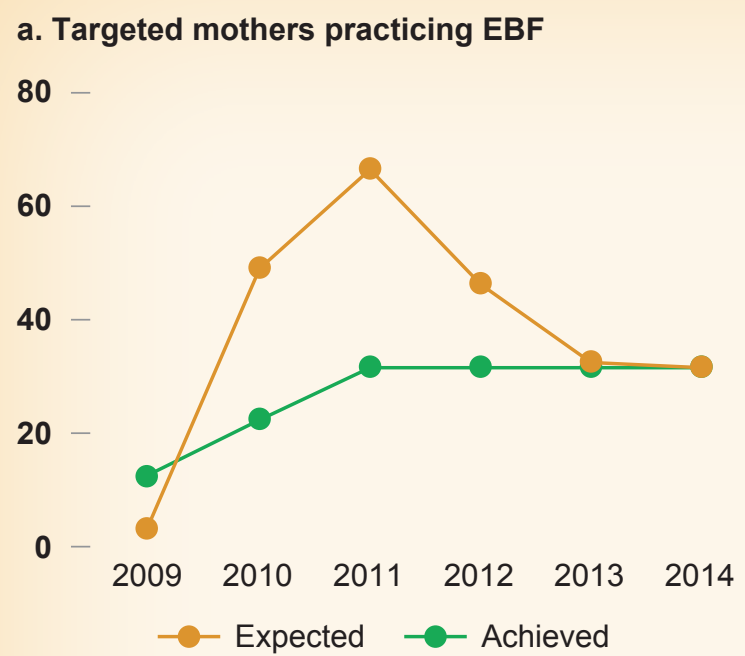

c. Targeted population reached by PRN

80

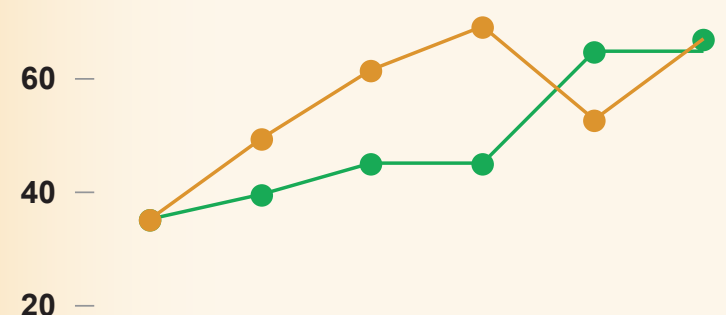

0

$\begin{array}{llllll}2009 & 2010 & 2011 & 2012 & 2013 & 2014\end{array}$

- Expected $-\longrightarrow$ Achieved b. Children 6-59 months screened quarterly for SAM 100

80

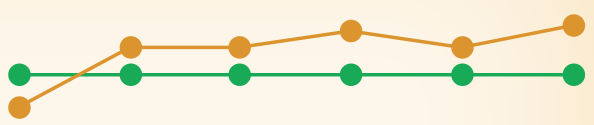

60

$40-$

$20-$

0 $\begin{array}{llllll}2009 & 2010 & 2011 & 2012 & 2013 & 2014\end{array}$

- - Expected $\rightarrow$ Achieved

d. Oil and salt fortification

200,000
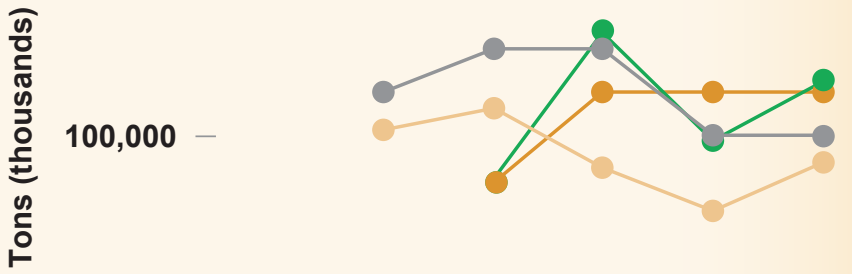

0

$\begin{array}{llllll}2009 & 2010 & 2011 & 2012 & 2013 & 2014\end{array}$

- - Quantity of fortified oil expected

- Quantity of fortified oil achieved

- Quantity of iodised salt expected

Quantity of iodised salt achieved

Source: CLM 2015. 


\section{Beneficiary satisfaction}

There is no validated system for assessment of beneficiary satisfaction. However, a "satisfaction survey" for BEN was conducted in 2005 , and similar data are collected periodically during monitoring missions. This information has been used to assess the perceptions of administrative authorities regarding PRN, PASAV, RBF, and other projects and programs. Additionally, the BER of Thiès has conducted focus groups during field visits to assess beneficiary satisfaction.

With respect to ministerial entities, anecdotal evidence indicates that beneficiaries think the services are working properly. Some ministries have expressed the intention to establish a system dedicated to the collection of users' opinions. However, to date, because there is no clearly established system for the collection of data on beneficiary satisfaction, its use to enhance the programs is limited.

\section{RECOMMENDATIONS:}

- The BEN's mission should be revised to better align with the reality that has developed over time and with practical experience: That is, the BEN now functions as the operational arm of the CLM. As such, it plays a critical role in the execution of the CLM's mission, holding responsibilities that extend beyond the functions it was assigned 15 years ago.

- More systematic collection of information on beneficiary satisfaction would enhance program efficiency.

\section{Effectiveness of Units of Analysis}

Based on IOCA survey results, nutrition stakeholders range widely in their opinions regarding returns on nutrition investments (figure 8), with 35 percent of respondents "agreeing" that the sector is effective in carrying out its mission; 21 percent "disagreeing" ("do
FIGURE 8: Responses to IOCA Survey Question on Effectiveness

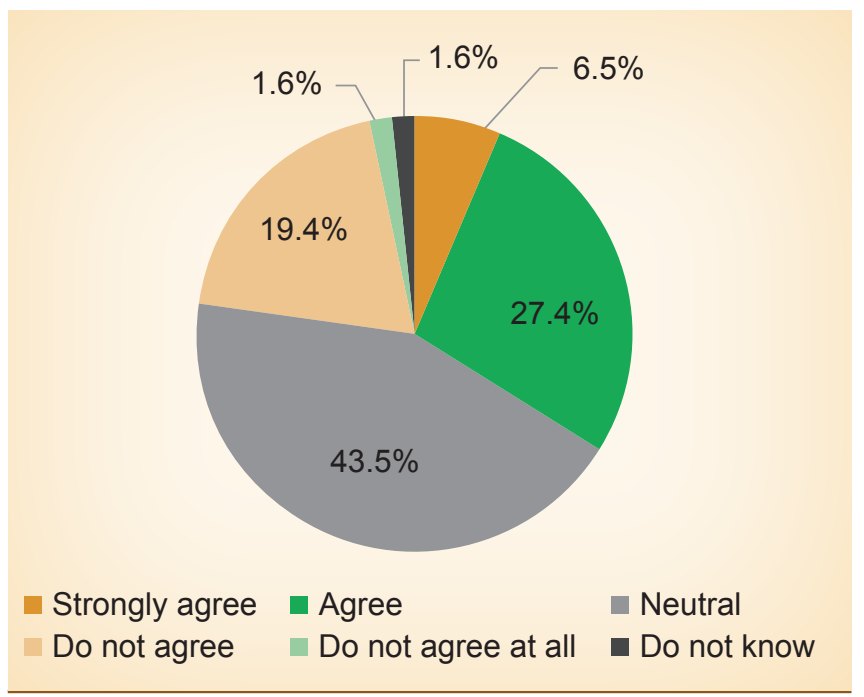

Source: Based on online surveys conducted by the IOCA, June-July 2016.

not agree" or "do not agree at all"), and 44 percent having no opinion (that is, "neutral").

As with the IOCA assessment of efficiency, a qualitative assessment of effectiveness was conducted to compliment the survey results. As discussed below, three indicators guided the assessment: (1) use of human resources and distribution of budget expenses; (2) use of materials and facilities (such as buildings and equipment); and (3) use of financial resources.

\section{Human resources and distribution of budget expenses}

Staff from multiple units of analysis reported that, despite insufficient personnel and limited resources, the various entities manage to obtain satisfactory results. This was attributed to personnel of the various institutions working long hours to reach the expected results.

With respect to the distribution of budget expenses, BEN's management fees (including wages) over the last 12 years have been below 20 percent of its annual budget (except for 2006 when they reached 
27 percent), permitting the majority of expenditures to be on program activities (figure 9 ).

At the MAER, the proportion of expenses related to staff and operations from 2011 to 2015 was between 2 and 4 percent (MAER 2015). For MSAS, the financial report of 2009-12 shows the proportion of expenditures spent on operations to be approximately 21 percent, while the proportion of expenditures spent on personnel was approximately 47 percent.

\section{Material resources}

With respect to material resources, it is clear that buildings and equipment are overused. At the BEN and BER levels, many vehicles and equipment date from 2002. Although in working condition, these resources are largely outdated.

\section{Financial resources}

Cost control and maximization of impact are key goals of the nutrition sector. These values are reflected within most units of analysis, where the ratio of financial resources to results was reported to be cost effective. Sound financial management procedures and mechanisms were credited.
At BEN, the organizational values, the control systems (manual of procedures, by-laws, and attendance register), routine staff performance assessments, program monitoring tools, and ABAP reviews promote effectiveness. In addition, BEN has a financial management plan and undergoes routine annual audits.

DAN, MEPA, DAPSA, and DCMS each have multiannual expenditure programming documents, along with an outcome-assessment framework and methodology (indicators and assessment calculation). Internal technical, administrative, and financial inspections are periodically performed. However, many of these mechanisms-which are important elements of all state services that ensure an effective use of resources-are underfunded and short-staffed.

\section{Relevance}

The IOCA assessed relevance based on (1) satisfaction of nutrition sector stakeholders and (2) agencies' ability to adapt to a changing context and stakeholders' needs. (Due to study constraints, this component of the assessment was limited to the CLM and the BEN.)

FIGURE 9: Breakdown of BEN Budget Expenses

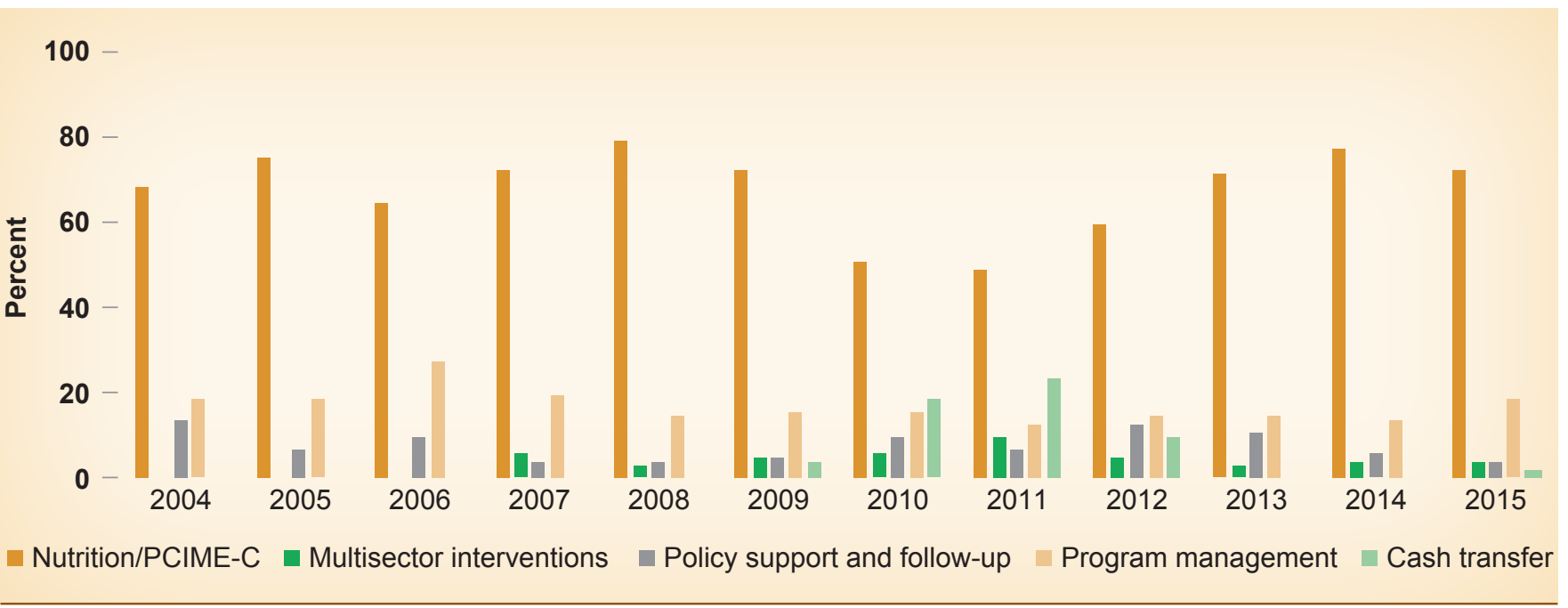

Source: CLM funding synthesis document (2004-15).

Note: PCIME-C = Community Integrated Management of Childhood Illnesses. 


\section{Stakeholder satisfaction}

Seventy-one percent of nutrition sector stakeholders at both national and regional levels reported being "satisfied" (47 percent) or "very satisfied" (24 percent) with the CLM's approach to its mission (figure 10). Based on these results, the CLM and BEN can be considered high performing in terms of relevance.

\section{Adaptation to nutrition sector evolution and to stakeholders' needs}

In recent years, the BEN has revamped its structure both for content and approach, and the CLM has made efforts to strengthen its capacity for multisectoral action, prompting greater satisfaction among stakeholders. Targeting methods, packages of services and the geographic coverage of programs have evolved in response to changing national and international standards including protocols, policy directions, and evidence and priorities.

More could be done however, to sustain the CLM's and BEN's relevance. This is particularly true with respect to institutionalization by line ministries of nutrition, for example, improved provision of qualified human resources, and better integration of objectives and stronger alignment of policies. Securing increased funding and maintaining political support are also imperative.

\section{RECOMMENDATIONS:}

- The BEN's mission should be revised to better align with the reality that has developed over time and with practical experience: That is, the BEN now functions as the operational arm of the CLM. As such, it plays a critical role in the execution of the CLM's mission, holding responsibilities that extend beyond the functions it was assigned 15 years ago.

- More systematic collection of information on beneficiary satisfaction would enhance program efficiency.
FIGURE 10: Nutrition Stakeholder Responses to: "What Is Your Overall Level of Satisfaction with the CLM Mission?"

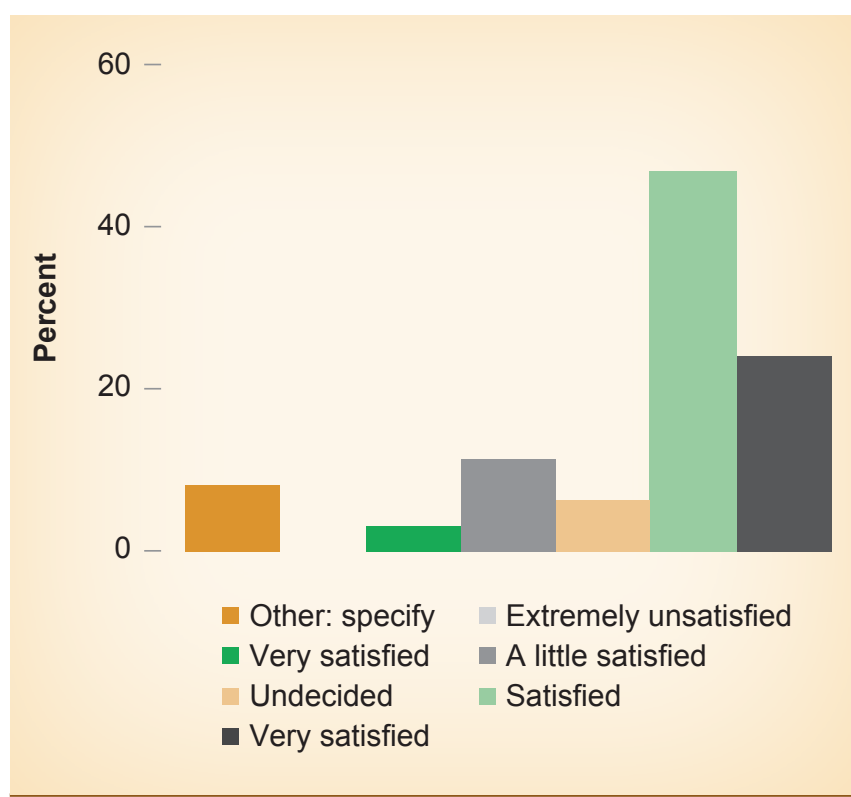

Source: Based on online surveys conducted June-July 2016.

\section{RECOMMENDATIONS:}

The CLM should work with various stakeholders toward the following goals:

- Stronger communication on the impressive effectiveness of nutrition investments to enhance sector visibility and increase stakeholder trust

- Strengthened multisectoral collaboration through a multisectoral platform that is operational at the national, regional, departmental and grassroots levels to improve harmonization of planning and efficient use of resources; a critical component of such a platform would be a monitoring and assessment system for for the collection and sharing of nutrition-related information, and a clarification of the roles and responsibilities stakeholders

- An analysis of the nutritional situation that defines a common vision of problems and solutions, clarifies relevant sectors' roles, and calls explicitly for better mobilization of resources

- Strengthened advocacy for academic training to educate a critical mass of nutritionists nationwide 


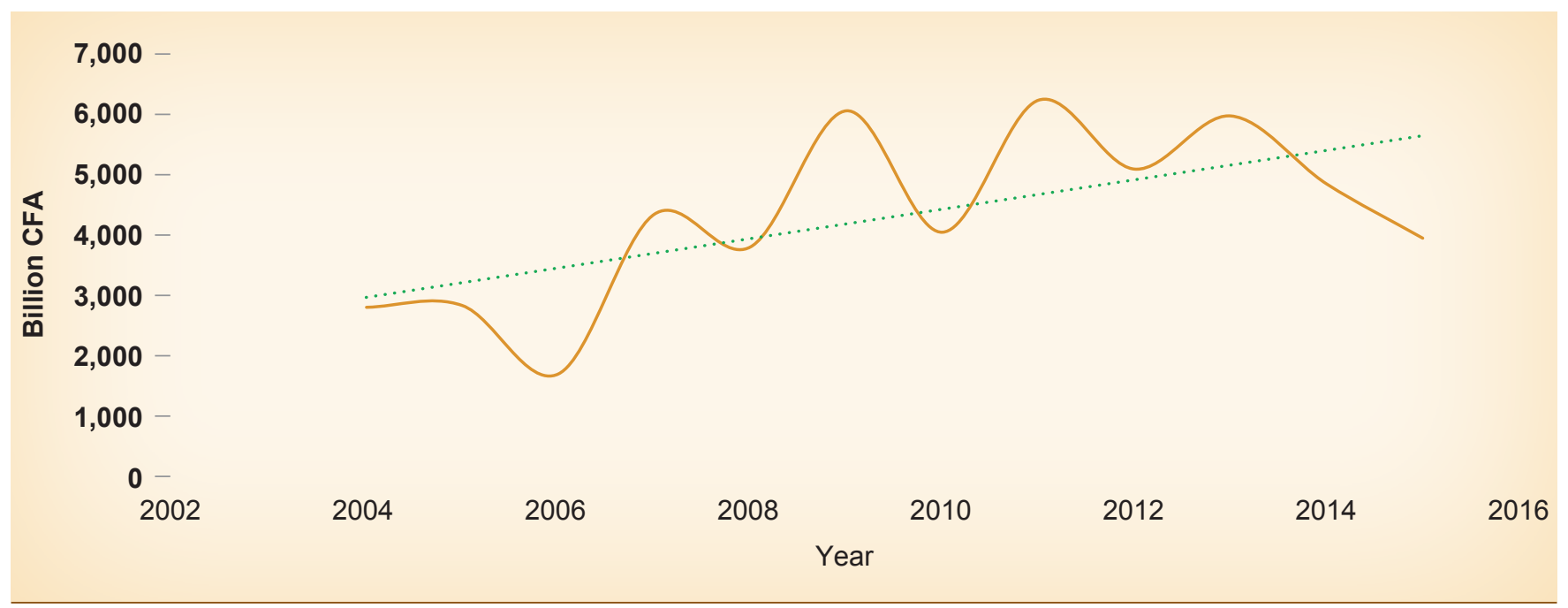

Source: CLM funding synthesis document (2004-15).

\section{Financial Viability of Units of Analysis}

Financial viability is the capacity of an organization to mobilize the necessary funds to meet its operational requirements in the short, medium, and long term. The observation in this assessment is that a substantial portion of CLM, MEPA, DAPSA, DCMS, and DAN resources come from the government of Senegal and bilateral and multilateral donors that provide funding for nutrition-specific and nutrition-sensitive programs. Here, we emphasize the available resources and the existing TFPs.

\section{Resources available}

The challenge of limited financing was repeatedly cited by all respondent organizations. On the whole, the level of resources does not match the level of ambition. Perhaps most notably, the BEN and CLM do not have adequate resources to scale up in terms of broadening their package of services or expanding coverage. While the CLM's financial resources have seesawed dramatically since 2004 , there has been a marked downward trend in recent years (figure 11).

Additionally, CLM is often forced to prepare its budget in a climate of uncertainty that requires midyear amendments to adjust to changes in resources and cash flow. For example, information on government budget allocations after 2016 was unavailable at the time of this assessment in June 2016.

With respect to line ministry entitites, the state budget covers operations, while projects, programs, and some additional items are funded by TFPs (see next section). Notably, DCMS receives no resources from the government for nutrition, even though nutrition is stipulated in the PAQUET-EF.

\section{TFPs}

All the units of analysis have TFPs, including INGOs, bilateral and multilateral organizations, United Nations agencies, global movements, and private enterprises.

\section{CLM and BEN}

The CLM and BEN have leveraged the adaptation and reorientation capacities of the PRN, its network nationwide (58 districts, 400 of $567 \mathrm{CLs}$, and 14 regions), and its countrywide coverage to gain the trust of TFPs and seize opportunities to mobilize additional resources.

From 2004 to 2015, the government provided 36 percent of CLM's funding and the remainder was provided by donors, with the World Bank providing the lion's 
FIGURE 12: CLM Funding Sources 2004 to 2015

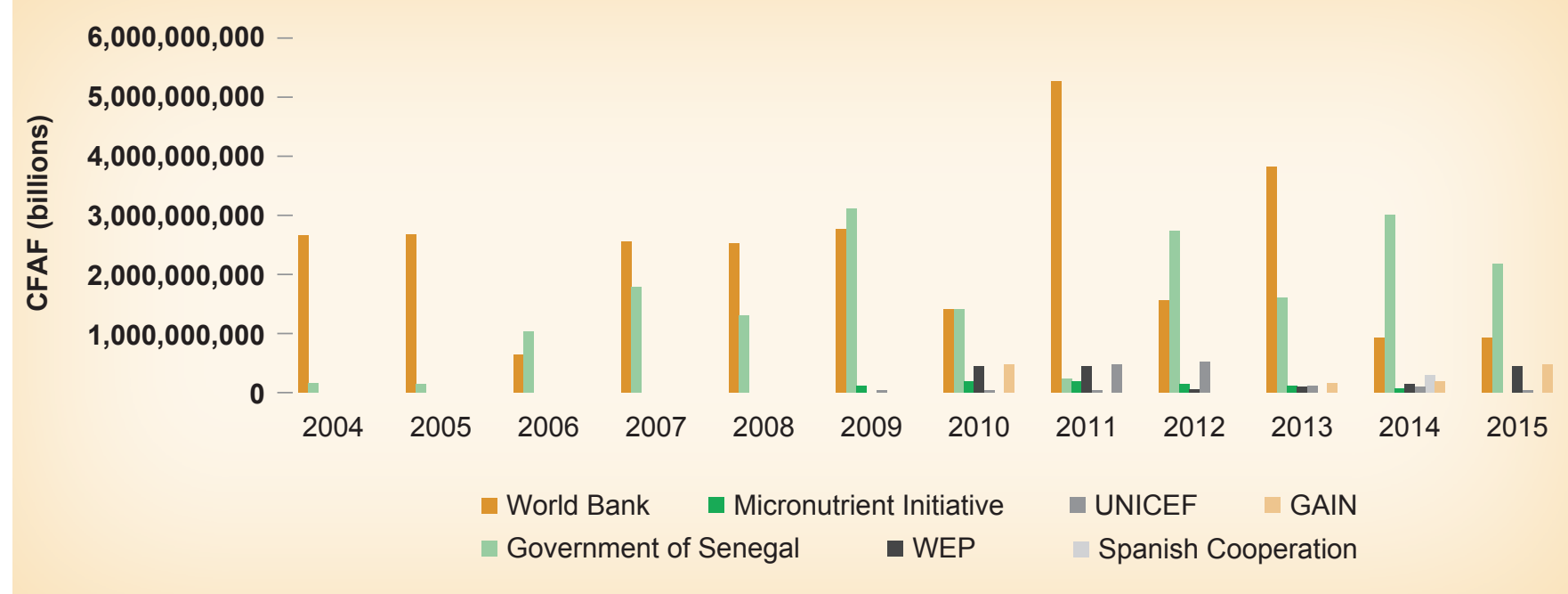

Source: CLM funding synthesis document (2004-15).

share (56 percent), UNICEF providing 4 percent, and $\mathrm{MI}$, GAIN and WFP together contributing 2 percent (figure 12).

The BEN has secured support for various programs and projects from TFPs including the World Bank, GAIN, WFP, UNICEF, MI, Banque Africaine de Développement (African Development Bank) (AfDB), the Spanish Cooperation Agency, the European Union, and the Government of Canada. Overall, donors' financial support of the BEN's budget has fluctuated between 95 percent (in 2004-05 and again in 2011), to less than half (in 2006 and again in 2012). In 2015, the last year for which numbers were available when this report was written, TFPs' contributions to the BEN stood at 45 percent (figure 13).

\section{DAN, DCMS, DAPSA, MEPA and MAER}

Unlike the other ministerial entities included in this analysis, TFPs support both projects and staff operations at the DAN (table 9). DAN is also a member of regional and international platforms including the Afri-

FIGURE 13: Donors' Financial Support of the BEN 2004-2015

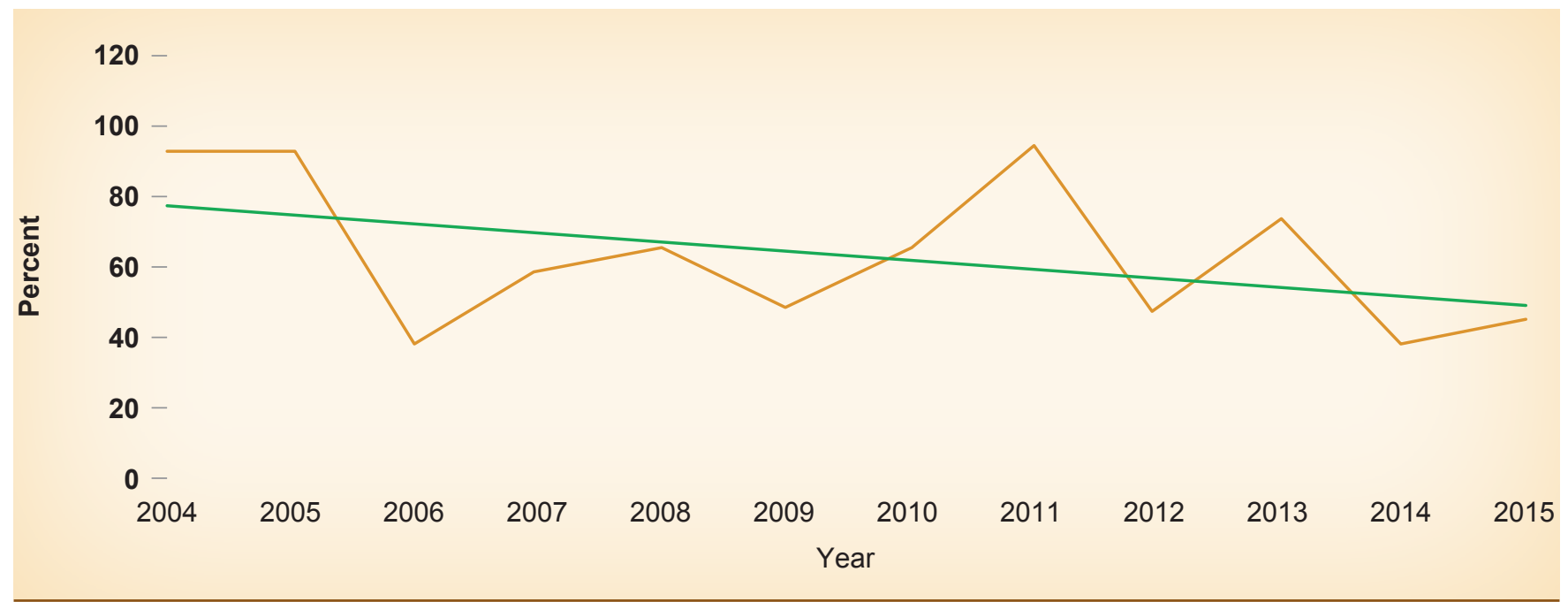

Source: CLM funding synthesis document (2004-2015). 
can Union, WAEMU, Union Economique et Monétaire Ouest Africaine (Economic Community of West African States) (ECOWAS), the SUN Movement, REACH, Alliance Globale pour la Résilience (AGIR)—Sahel et Afrique de l'Ouest (Global Alliance for Resilience (AGIR)-Sahel and West Africa) (AGIR), and Nouvelle Alliance pour la Sécurité Alimentaire et la Nutrition (New Alliance for Food Security and Nutrition) (NASAN).

DCMS receives funding for nutrition projects, the Healthy Kids program, and other occasional funding from TFPs.

MAER and MEPA both receive TFP support for food security and nutrition-sensitive projects and programs. Overall, between 2011 and 2015, foreign financial support for MAER was estimated to be 42 percent $^{6}$ of the overall budget, and at the time this report was written, external donors were projected to be providing 98 percent of the budget for MAER. It was also noted that MAER receives extensive technical support from the World Bank, Agence des États-Unis pour le Développement International (United States Agency for International Development) (USAID), AfDB, India's International Cooperation Agency, China's International Cooperation Agency, Agence Coréenne de Coopération Internationale (Korean International Cooperation Agency) (KOICA), Agence de Coopération Internatio- nale du Japon (Japanese International Cooperation Agency) (JICA), and United Nations agencies.

The heavy dependency on a wide range of TFPs has pluses and minuses. On the one hand, the diversification in funding sources enables the sector to weather variations in funding by individual agencies. On the other hand, nutrition programming in Senegal is highly vulnerable as foreign funding is unstable. An additional challenge is sustaining coordination between partners and harmonization of interventions and strategies in the best interest of the country.

\section{RECOMMENDATIONS:}

- To reduce vulnerability and increase donor harmonization, a budgeted nutrition action plan that includes evidence-based resource mobilization strategies should be developed. This plan should take available funding into account and also target additional external and internal resources (including government and CLs as well as TFPs).

- A multisectoral action plan is essential to harmonize and coordinate nutrition sector investments. 


\section{Strengths and Obstacles}

\section{Nutrition Sector Strengths}

Seven strengths were identified by the IOCA:

- The stable political situation. Political stability in Senegal is a major positive factor for nutrition, which, for over a decade, has enabled the furtherance and consolidation of the government's nutrition policies.

- Existence of the CLM and its institutional anchorage in the Prime Minister's office. The CLM, entrusted with a clear coordination mandate and placed within the Prime Minister's Office, has laid the foundation for a multisectoral nutrition strategy. The CLM has established and consolidated its reputation through thorough and transparent management of national programs and projects, whose implementation by the BEN has been an undeniable success. For 15 years, CLM has fostered a critical mass of stakeholders in the field of nutrition, and there is growing consensus on the importance of multisector coordination in the development of the nutrition sector.

- Well-articulated nutrition policies and programs. Senegal's nutrition policies have improved with the evolution of knowledge in the sector, capitalizing on the global environment and on experience and lessons learned, as shown in the section on the institutional environment. The PNDN reflects that knowledge as well as national ambitions in the field of nutrition, and is well-aligned with the PSE. Nutrition is also clearly addressed in the PSE and other national policy documents. Senegal has, through CLM, successfully implemented nutrition programs, such as PRN, with visible results such as the improvement in the rate of stunting.

- Provision of state funding and donor support. Nutrition funding is provided by the government through a direct budget line for nutrition in the national budget, which has been increasing since 2001, and a requirement for an explicit line for nutrition in the budgets of CLs. (The adoption of Decentralization Act 3 in 2013 reaffirmed local governments' responsibility for the funding and implementation of nutrition programs.) In addition to these government efforts, donors, whose numbers continue to grow with time, have made contributions. This financial support has made it possible for the nutrition sector to achieve tangible results. The WAEMU reform may enable the adoption of multiyear budgeting in the nutrition sector, providing more visibility for planning. 
- Senegal's adherence to the SUN Movement and the REACH initiative. Senegal joined the SUN Movement in 2011 and the REACH initiative in 2014. Both have improved the country's visibility at international level, increasing recognition of its efforts and successes, and improving access to foreign resources, partnerships, and information. It has also facilitated the sharing of experiences with other countries and the adoption of approaches for the development and strengthening of the nutrition sector, with particular emphasis on governance.

- Institutionalization of the multisector approach. Placement of the CLM within the Prime Minister's Office is a clear indication of the government's commitment to the multisectoral approach and to nutrition mainstreaming. In principle, relevant ministries are required to include an explicit budget line for nutrition and to produce reports on designated nutrition-related indicators. Multisectoral partipation in preparation of the PNDN and the launching of an inclusive process for development of the PSMN are additional indicators of the government's commitment to multisectoralism.

- A postgraduate nutrition program, which awards master's and doctoral degrees, has been initiated at UCAD. Although enrollment capacity is constrained by the low number of teachers, this program offers opportunities to strengthen nutrition-related capacity nationwide.

\section{Nutrition Sector Obstacles}

The IOCA identified seven major obstacles to optimal development of the nutrition sector in Senegal.

- Poor nutrition mainstreaming in line ministries. Senior authorities in key ministries do not act to sufficiently mainstream nutrition. According to the PNDN and related documents, these ministries are CLM members and ministerial nutrition focal points are critical to nutrition mainstreaming. In practice, however, there is very little attention paid to nutrition interventions by line ministries. Most of the nutrition interventions undertaken by these sectors, with a few exceptions, are funded by the CLM. Intrasectoral collaboration is poor, and nutrition focal points often work in isolation, with their activities disregarded or considered external to the sector's interests. The challenge is exacerbated by the lack of initiative on the part of many focal points. Most do not play the role of nutrition champion by engaging leaders of their sector or otherwise advocating strongly for nutrition. Budget allocations dedicated to nutrition often do not exist in line ministries; when nutrition interventions are scheduled, the resources are generally expected to come from donors and as such are subject to the uncertainties of foreign funding. Unless leadership within the sectors becomes more committed to nutrition mainstreaming, the recent participation by line ministries in the development of the PSMN will serve no purpose.

- Poor coordination of stakeholders in the nutrition sector. The problem of coordination at the national, regional, and local levels is acute, even though various networks (such as for TFPs, NGOs, the private sector, and research) have been created through the SUN Movement. These networks facilitate coordination and collaboration among groups of stakeholders, but nutrition interventions across all stakeholders are not always harmonized, and the presence of multiple stakeholders leads to duplication and overlapping of effort. After 15 years, CLM still hasn't operationalized this aspect of its mission. Current efforts to do so are limited to convening multisectoral meetings, hosted either by the BEN or CLM, or by another stakeholder of the sector, depending on the need. It is hoped that additional progress can be made by leveraging the collaborative approach that was used to develop the PNDN. This process created enthusiasm and hope among stakeholders regarding development of a framework for coordination, including a clear shared vision and well-defined roles and responsibilities.

- Shortfalls in the CLM's leadership role. Through the success of the PRN and the provision of funding for sector-specific nutrition interventions at the decentralized level, the CLM has established its leadership role. However, the CLM's mission goes beyond PRN; the evolution of the nutrition sector 
requires more systematic coordination across sectors. Stakeholders at the national, regional, and departmental levels unanimously agree that the CLM needs to take on this role more aggressively.

- Heavy dependence on foreign funding and poor coordination of TFPs. The nutrition sector is highly dependent on foreign funding. Between 2012 and 2015, foreign funding paid for 88 percent of nutrition expenditures, compared to 12 percent covered by government (Offosse N. 2018). This situation creates vulnerabilities that are further exacerbated by poor coordination between TFPs. Even when foreign funding goes through the Ministry of Finance, assets are not coordinated at the central level for consistency and harmonization. Despite the efforts of the SUN Movement (through the creation of the donor-United Nations platform) and the existence of the PNDN, there is no common nutrition funding platform built around the priorities of the government. Rather, TFPs provide ad hoc funding to the various sectors (such as health, agriculture, livestock, and education) in isolation for nutrition-specific or nutrition-sensitive programs, increasing competition and discouraging collaboration. It is hoped that the PSMN will galvanize establishment of a single funding system for the entire nutrition sector, creating new incentives for collaboration and improving coordination of TFPs.

- Limited technical capacities of the nutrition sector. Weaknesses in nutrition-related capacity are evident from the central to the local level, and stakeholders stress the need to strengthen their knowledge in nutrition. Lack of knowledge was marked in the disengagement of some stakeholders, who were not aware of the importance of their sector's role in improving nutrition outcomes.
Only in the health sector have personnel received any training in nutrition; those in the agriculture, livestock, and education have not. This oversight can be largely attributed to the fact that nutrition is not recognized as a profession by the Senegalese civil service. As long as this perception persists, students will be discouraged from pursuing nutrition studies and the BEN, CLM, and other entities will grapple with problems posed by a shortage of nutritionists.

- Inadequate human resources and low incentives. Findings from the IOCA's analysis of organizational structure within the various units of analysis indicate an increasingly limited functional capacity from central government downward. A majority of civil servants reported feeling demoralized by poor incentives and a feeling of being overworked.

- Inadequate attention to training and research in nutrition. Government support for training and research in the field of nutrition is inadequate. For the past 50 years, the government has focused on research done by the ITA on promoting the consumption of local products. However, climate change has made the challenges of food and nutrition security increasingly complex, and with the transformation of the nutrition environment, new challenges have emerged. Addressing the country's vulnerability to climate change will require substantial investments in research, especially to develop seeds adapted to climate conditions and products with high nutritional value. It is hoped that the launch by the University of Sine Saloum in Kaolack of a training and research unit in nutrition and food in 2017 will help strengthen the capacities of academic institutions in the training of human resources in nutrition. 


\section{Guidelines for Strengthening Institutional and Organizational Capacity within Senegal's Nutrition Sector}

The guidelines below aim to improve three components of Senegal's nutrition sector: governance, resources, and training.

\section{Component 1: Governance of the Nutrition Sector}

Five recommendations for enhancing governance of the nutrition sector are presented below.

\section{Strengthen CLM leadership for optimal accomplishment of its mission}

(See table 9, theme 3 for more details on this recommendation)

The CLM's scope of action must be reoriented to include a much stronger emphasis on multisectoral collaboration. Since its inception, the CLM has concentrated on validation of the ABAPs and FPRs prepared by BEN as part of PRN. While clearly successful in terms of PRN outputs, this approach has detracted from the need to promote multisectoral collaboration. Revitalizing the CLM's internal operations and better aligning BEN's mission with that of the CLM are two strategies for strengthening this critical focus:
- Revitalizing CLM's internal operations. It is essential that the CLM, through its chairman, create technical working groups to generate internal momentum and to affirm CLM leadership in nutrition. These working groups would play a critical role in assessing how CLM leadership can be improved and provide important inputs to a CLM action plan.

- Better aligning BEN's mission with that of the CLM. As the CLM depends on BEN for implementataion, an amendment should be made to the latter's misson to add "coordinating the nutrition sector and consolidating multisectoralism." To operationalize this amendment, BEN's institutional structure would need to be revamped to include a unit in charge of multisectoralism. Staff for this unit would need diverse expertise including organizational governance, strategic communication, advocacy and fund raising, and relations with TFPs.

\section{Ensure multisectoral coordination within the nutrition sector}

(See table 9, theme 3 for more details on this recommendation)

Multisectoral coordination of the nutrition sector is critical to optimizing contributions from different sectors 
and for ensuring consistency of nutrition interventions at different levels. Coordination of different sectors is closely linked to CLM leadership; it includes intrasectoral and intersectoral collaboration and should emphasize the strengthening of each relevant sector's nutrition promoting activities, as follows:

\section{- Encourage intrasectoral collaboration on nu-} trition with CLM focal points as initiators. CLM focal points should play a key role in intrasectoral collaboration by fostering distribution of nutrition information to as many departments as possible within a given sector, and by advocating for the inclusion of nutrition in sectoral planning activities. The CLM must establish nutrition coordination units and place focal points in strategic positions within member sectors. Additionally, CLM member sectors should be required to establish nutrition steering committees and to develop action plans comprising explicit nutrition-promoting activities.

- Establish a multisector, multistakeholder coordination platform at the national level. Led by the CLM, this platform would complement the sector-specific coordination units described in the preceding bullet and would leverage previously established SUN Movement coalitions. The goal would be to foster regular dialogue on strategies for promoting nutriiton, with emphasis on identifying responsibilities and roles for different sectors and stakeholders.

- Strengthen sectoral and multisectoral coordination at the regional level. Bottlenecks and inconsistencies between the central and regional levels are major challenges to Senegal's nutrition sector. The CLM should engage BERs to leverage current and planned decentralized entities such as CRSs and regional SUN Movement platforms. In particular, it is recommended that the BERs act to strengthen the nutrition-related capacities of CRSs in leadership and governance. This requires a more dynamic framework than can be provided by CRSs given their current mandate, which is limited to harmonization of nutrition interventions and strategies at the regional level. CRS terms of reference should be revised to extend their mandate beyond CLM programs and projects implemented by BEN.
- Strengthen sectoral and multisectoral coordination at the local level. As at the regional level, BERs should, as the technical branches of CLM, also work to strengthen coordination at the local level. In this context, key partners include administrative authorities, existing decentralized services, and CLs. At the grassroots, they include Organisations Communautaire de Base (Community-Based Organizations) (CBOs) and communities themselves.

\section{Develop institutional communication strategies}

(See table 9, theme 2 for more details on this recommendation)

The following steps are recommended to improve the institutional communication strategies of the units of analysis and other nutrition entities:

- Enhance internal and external communication of organizations within the nutrition sector. The IOCA found that the units of analysis face communications challenges. The CLM and BEN should improve exchanges between their members by building on technological progress in communication. Sectoral entities should improve their internal communications as well as those with other decentralized departments and services. The creation of a functional web site that is systematically updated is essential to meeting these goals.

- CLM should develop an institutional communication plan for advocacy and BCC and to report on the results of the sector.

- Maintain a strategic dialogue with top management in relevant sectors. The CLM should initiate and foster the mainstreaming of nutrition through institutional communication with relevant sectors, such as health, agriculture, livestock, hydraulics, fishing, education, finance, and the CNSA, as well as with decentralized bodies. This dialogue would build trust and clarify the contribution of the sector in question to nutrition, making roles and responsibilities explicit and contributing to a culture of multisectoral accountability.

- Target members of parliament and other politicians regarding nutrition's position on the 
political agenda. This strategy is critical for maintaining and expanding government funding and is also important as it encourages politicians to integrate nutrition into their day-to-day discourse on development priorities. Key to such messaging is an emphasis on the importance of mainstreaming. Decision makers must be convinced of the need to strengthen nutrition-related actions across relevant sectors, especially with respect to allocation of adequate funding.

- Target TFPs. Strategies should be implemented by the CLM for permanent communication with TFPs to secure their commitment in the long term, and to coordinate interventions and maintain program alignment with government and other TFPs.

\section{Ensure strategic multisectoral and operational planning}

(See table 9, theme 3 for more details on this recommendation)

A major goal of nutrition mainstreaming is the appropriation of strategic and operational nutrition plans by multiple sectors. The CLM should use its control over the PSMN planning process to encourage this type of appropriation through joint planning, especially with respect to stipulation of clear and explicit budget allocations in member sectors. Alignment of the PSMN's development with the various sectors' DPPDs is an important strategy for achieving this goal.

\section{Establish a common results framework and an information and knowledge management system}

(See table 9, theme 5 for more details on this recommendation)

The PSMN calls for a common results framework that establishes accountability to nutrition across multiple sectors and at all levels. The CLM, in consultation with stakeholders, should establish monitoring and assessment mechanisms promoting timely collection of data at all levels. Additionally, the CLM should establish a system for the management of these data to inform timely decision making and to improve the quality and breadth of nutritional knowledge compiled over time. Ideally, the CLM would partner on this initiative with the CNSA and other institutions conducting large-scale surveys on nutrition so as to pool nutrition-related information and knowledge.

\section{Component 2: Resources}

Component 2 consists of the following three recommendations:

\section{Develop strategies for establishing a system of nutrition funding and resource mobilization}

(See table 9, theme 7 for more details on this recommendation)

The challenge of establishing a single funding system for nutrition programs and projects, including the scaling up of the PRN, is acute. Most sectors expect to carry out their nutrition interventions using CLM funds. The CLM should maximize its chances of receiving government funding first by finalizing its nutrition investment project document under the PSMN, and second by collaborating with ministerial entities, especially MEFP, to establish budget lines explicitly reserved for nutrition-specific or nutrition-sensitive interventions. These budget lines should stipulate whether funding is to be drawn from the CLM or from a ministry's own resources. The CLM should also employ mobilization strategies based on strategic nutrition documents, for example, advocating to government for an increase in funding with which to strengthen the PRN, and to help sectors with budget appropriations and meetings with donors. Finally, BEN and the BERs should work with the CLs to increase their contributions to nutrition funding.

\section{Strengthen human resources and enhance incentives}

(See table 9, theme 4 for more details on this recommendation)

The nutrition sector's human resource problems are attributable in part to an organizational structure that 
prioritizes staffing at the central level. The government should prioritize strengthening key state-level nutrition entities by raising salaries, increasing benefits, and recruiting additional personnel. Additionally, BEN should work to fill vacant posts as well as the new posts created by the revision of its organizational structure. BEN should also act to boost staff morale, which the IOCA found to be low.

With respect to sectoral entities, the CLM should provide focal points with adequate technical and financial resources. Sectoral entities should also ensure that at least some of their staff are capable of addressing nutrition issues and ensuring that their sector plays its role. To achieve this goal, nutrition-related knowledge of staff working in sectoral entities should be enhanced (for example, with respect to planning, statistics, and monitoring and assessment). An important strategy for increasing mainstreaming is revision of job descriptions to include performance indicators on nutrition.

Finally, in order to develop a national human resource strategy for nutrition, the CLM should conduct a country-wide assessment to determine training and staffing needs nationwide.

\section{Improve the technological and logistical capacity and infrastructure of units of analysis}

(See table 9, theme 4 for more details on this recommendation)

- Technological means. All units should upgrade their technological capacities. All the units of analysis should adopt new communication technologies to enhance their organizational performance and the CLM should create a communication platform to facilitate interaction among its members, as well as exchanges between stakeholders. With respect to telephone service, the nutrition sector should negotiate a preferential tariff that provides discounted rates to minimize expenses borne by staff. BEN should improve the capacity of its server and introduce a security and electronic data protection plan. It is also critical to introduce systematic updating of antivirus software, automatic and regular data backup on a central server, and systematic and regular maintenance of computer hardware. The BEN should also construct a viable Intranet to facilitate internal communications, and all units should train their staff in basic information technology security.

- Logistical means. The BEN should develop a policy to address depreciation of its vehicles and to facilitate renewal of its fleet to avoid using cars for over ten years, which leads to high maintenance and service charges. All units of analysis should establish their needs for logistical means at the central and regional levels and develop strategies for their acquisition.

- Infrastructure. The issue of inadequate working environments needs special attention. For the public services, the government should improve office space and equipment at both the central and decentralized levels. The DAN should advocate to its line ministry for funds for the construction and equipment of CREN units, and the BEN should seek funding to provide additional office space at the central level and in the regions. Building maintenance plans should be developed and observed by all units.

\section{Component 3: Training and Education}

\section{Strategic investment in training and education}

(See table 9, theme 1 and theme 6 for more details on this recommendation)

The IOCA found serious problems of nutrition-related capacity at all levels. The following steps are recommended.

\section{- Strengthen nutrition capacities of stakeholders} at all levels. The need for capacity building in nutrition has repeatedly surfaced as a leitmotiv for many stakeholders. It is essential that the CLM organize training sessions in nutrition for all sectors at the national level. This training should be two-pronged. The first prong should target leadership in relevant sectors (high-level staff in ministries, NGOs, INGOs, 
TFPs, research institutions, universities, the private sector, and the media). The second prong should target technical and operational staff in relevant sectors, including CLM focal points. These training sessions should be supplemented by activities such as experience exchanges, consultation meetings, and learning forums. At regional, departmental, and local levels, BERs should, with BEN support, conduct similar sessions for administrative authorities, CLs, and technical agents from relevant sectors to enhance their knowledge and skills in nutrition. At the grassroots, the capacities of community relays, traditional leaders, and communities should be strengthened by AECs.

\section{- Academic and professional training in nutrition.} Academic training in nutrition is very limited in Senegal. To expand opportunities, the CLM should join with academia to advocate to the government and to TFPs for the provision of education funding for the nutrition sector. In addition, UCAD should, in the short and medium term, attempt to expand its enrollment capacity, which is currently limited. For example, developing partnerships with other universities and hosting visiting professors could help make up for the lack of faculty. In addition, nutrition scholarships should be offered to increase interest among prospective students, and the government should formally recognize nutrition as a profession to facilitate Civil Service recruitment. Finally, the CLM should partner with vocational training schools that specialize in agriculture, livestock, agroindustry, and education for the introduction of training modules in nutrition; special emphasis should be placed on updating programs of nursing and medical schools in nutrition, both for content and number of hours.

- Continuous training and research. In partnership with the National Laboratory or other academic institutions, the CLM should develop online or short training modules to strengthen nutrition-related capacities. The CLM should also establish links with research institutions active in nutrition to encourage strategic research and to help advocate to the government and donors for research funding.

\section{Costed institutional and organizational capacity-building plan}

The need to build capacity that enables CLM member sectors, through their focal points, to work together to mainstream nutrition is the base on which this costed plan was developed. It covers the BEN and its BERs, as well as line ministries designated by the CLM for improved governance of the nutrition sector. Functional aspects of leadership, coordination, management, and monitoring and assessment are addressed. 


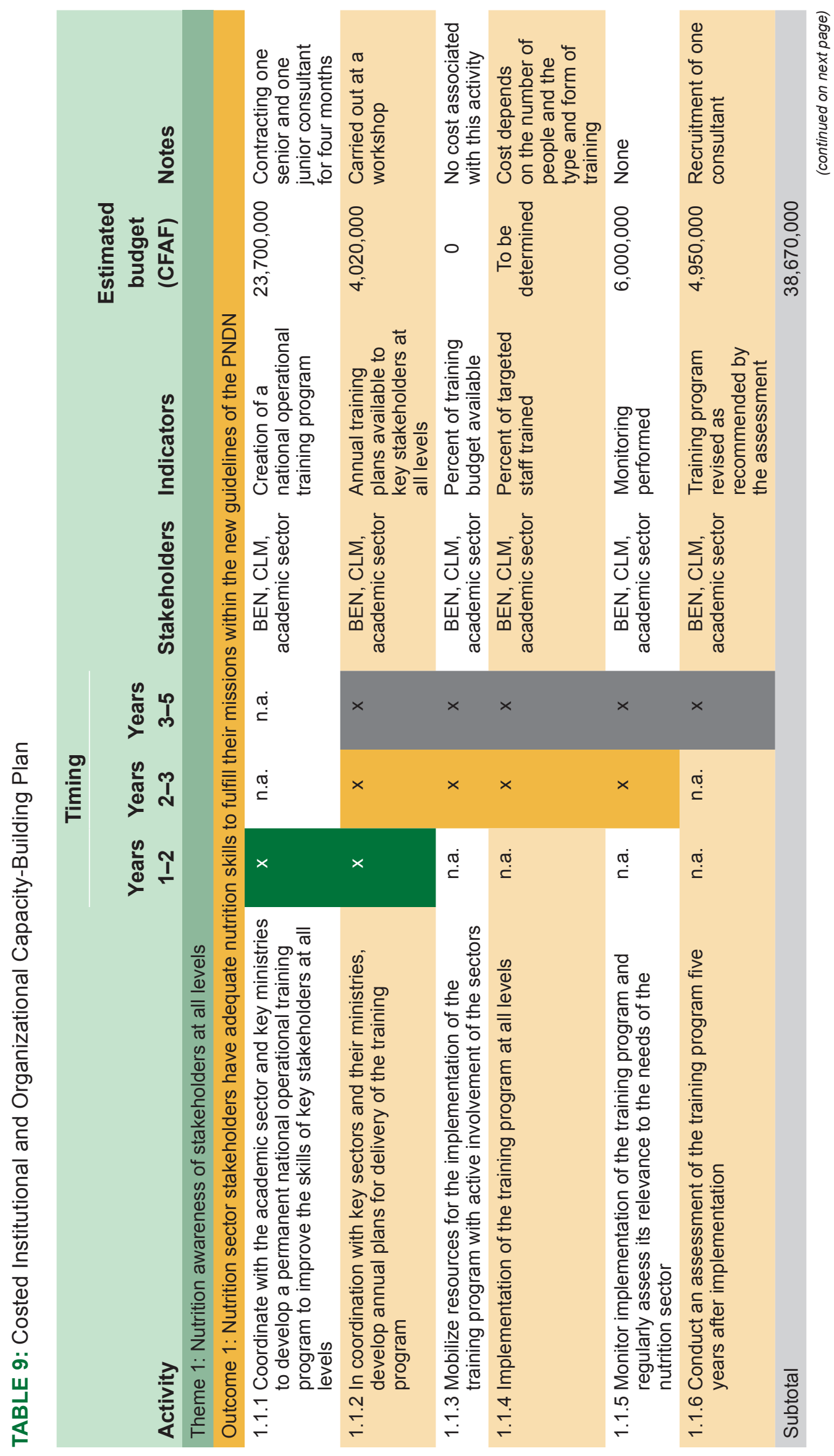




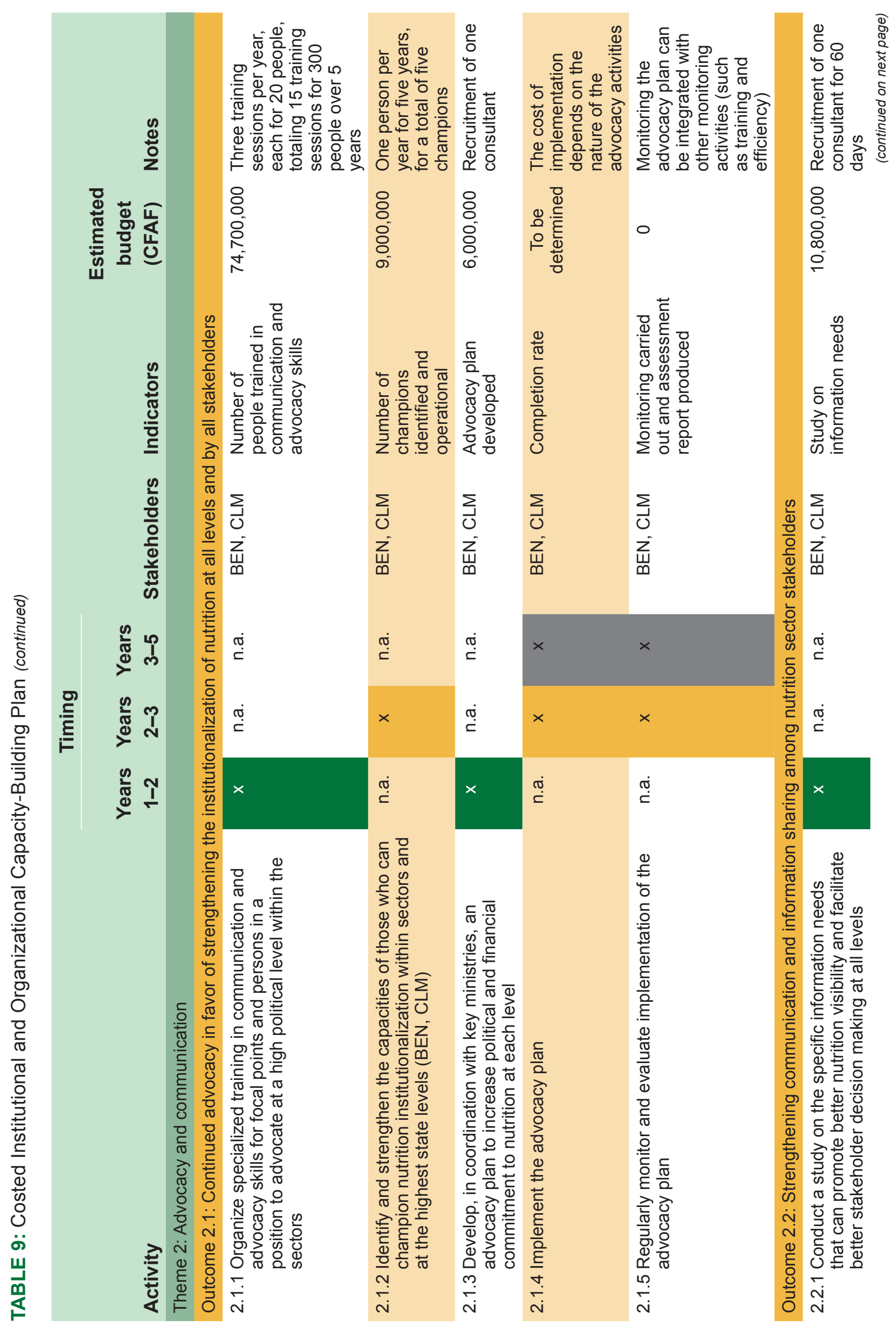




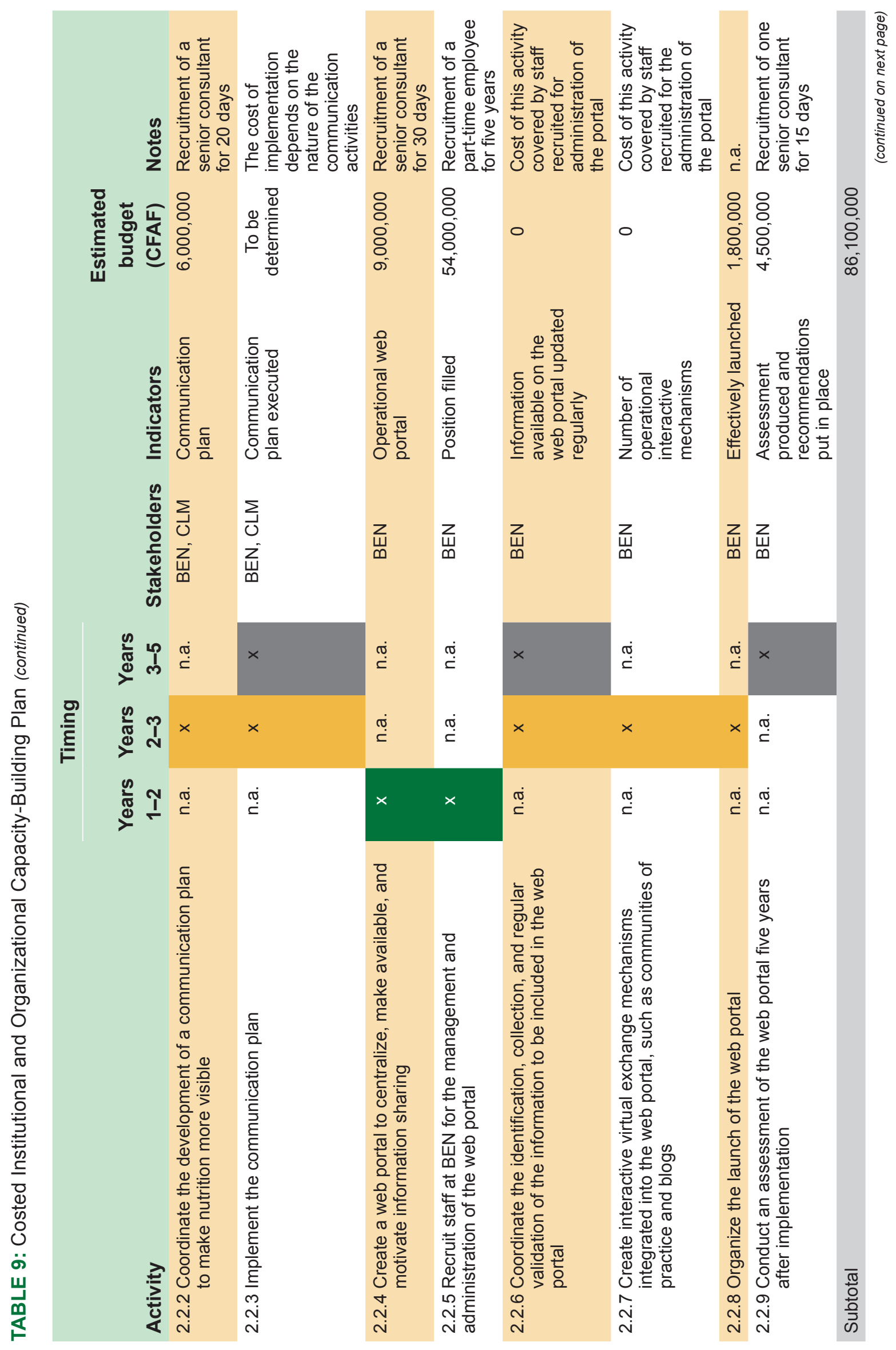




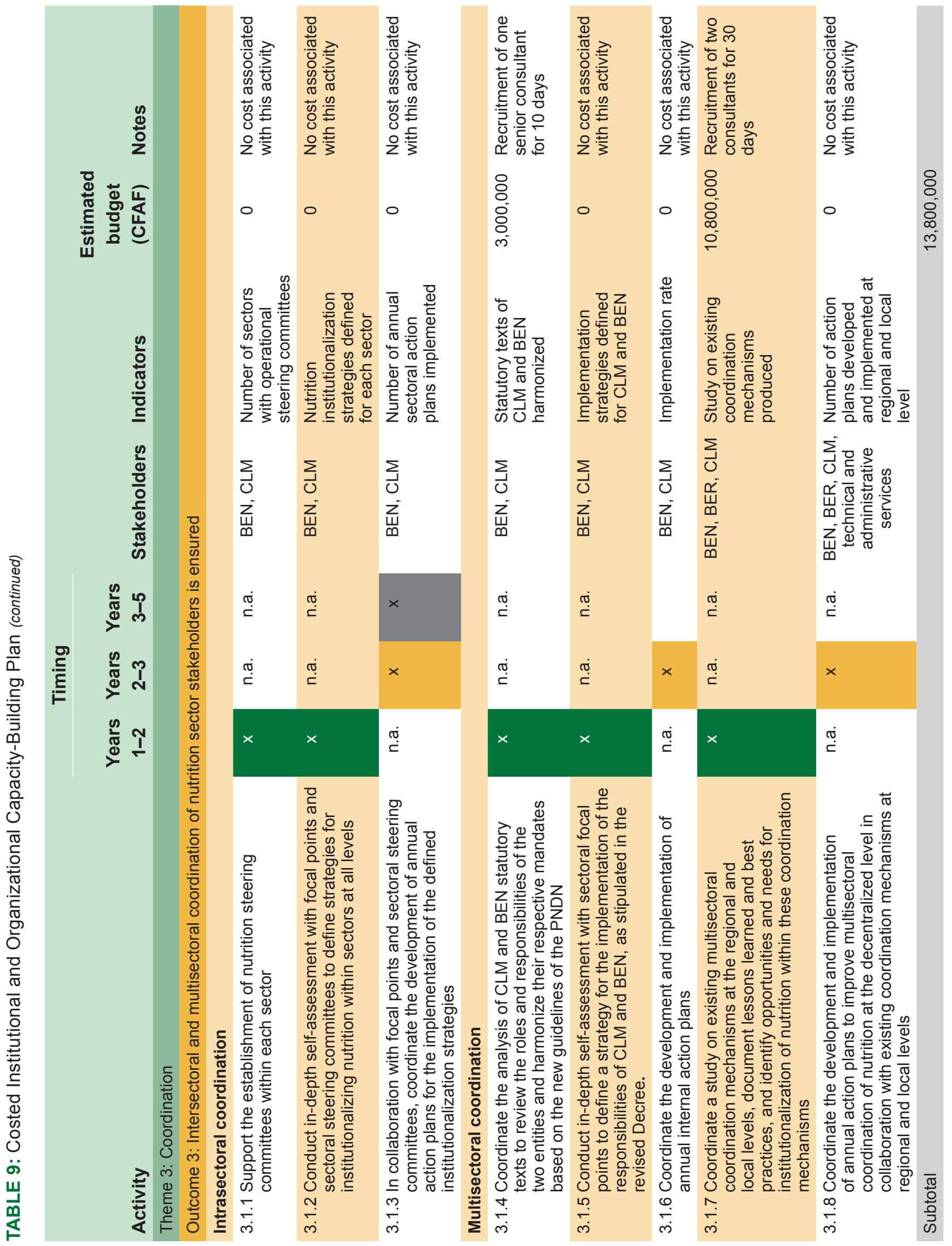




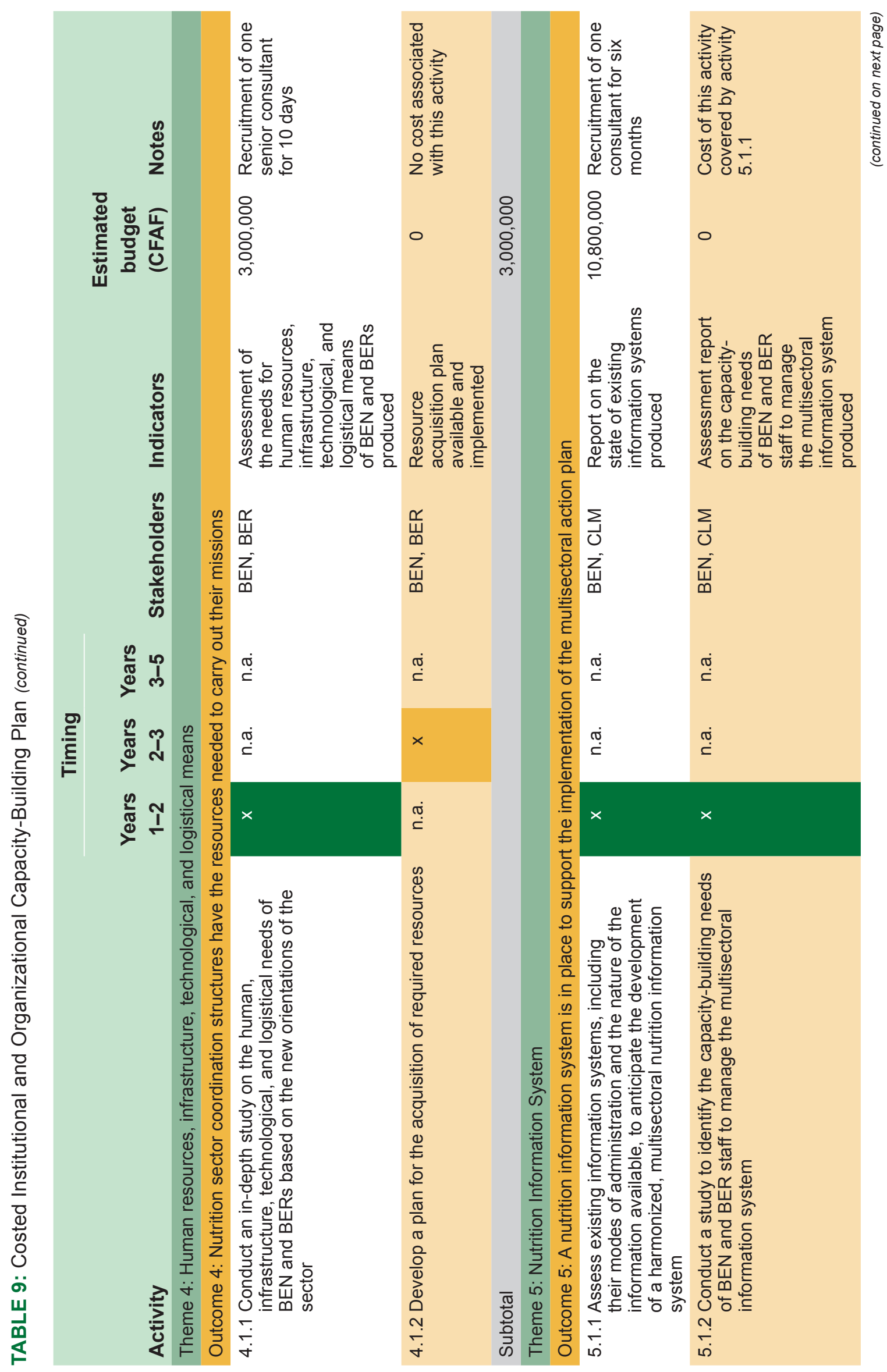




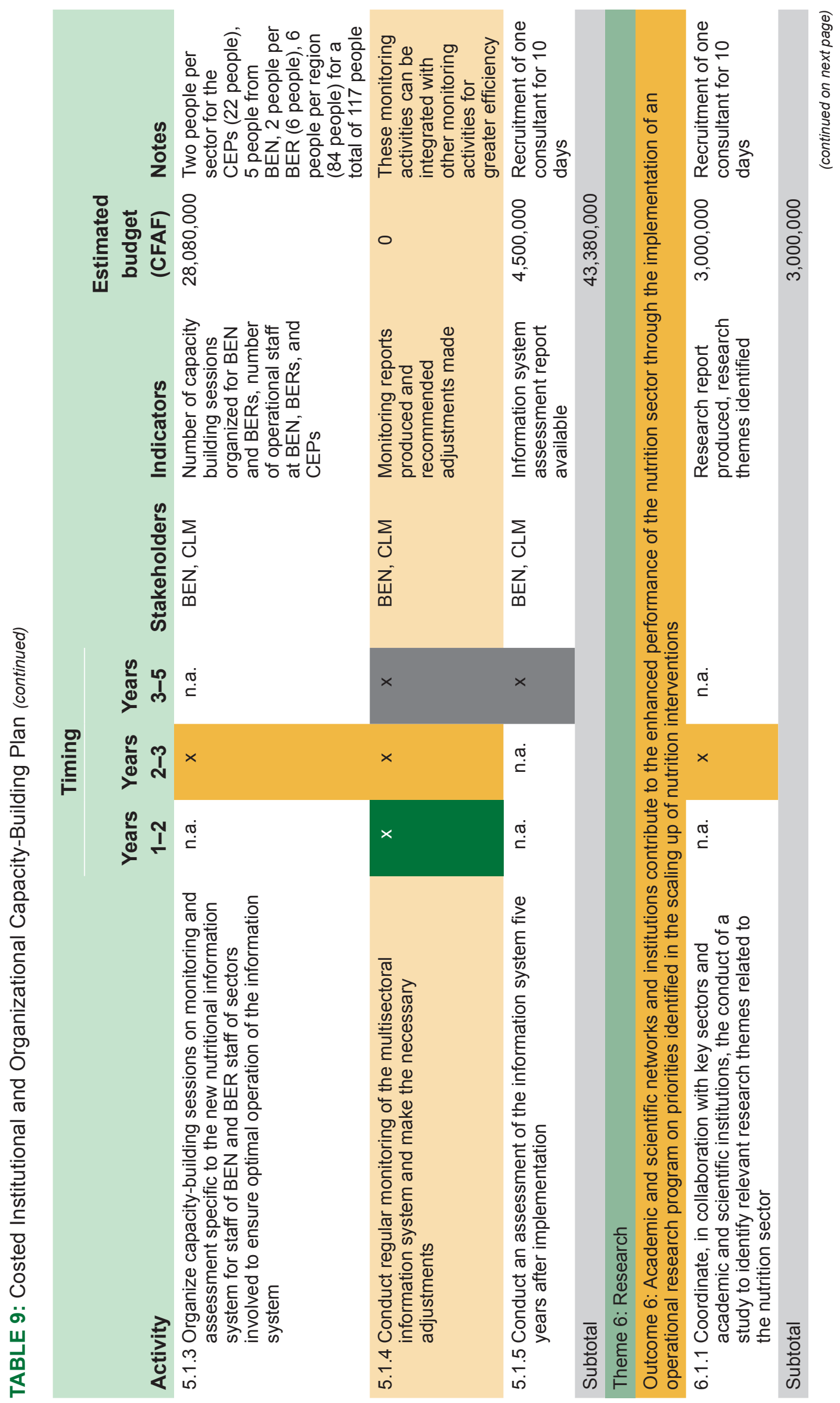




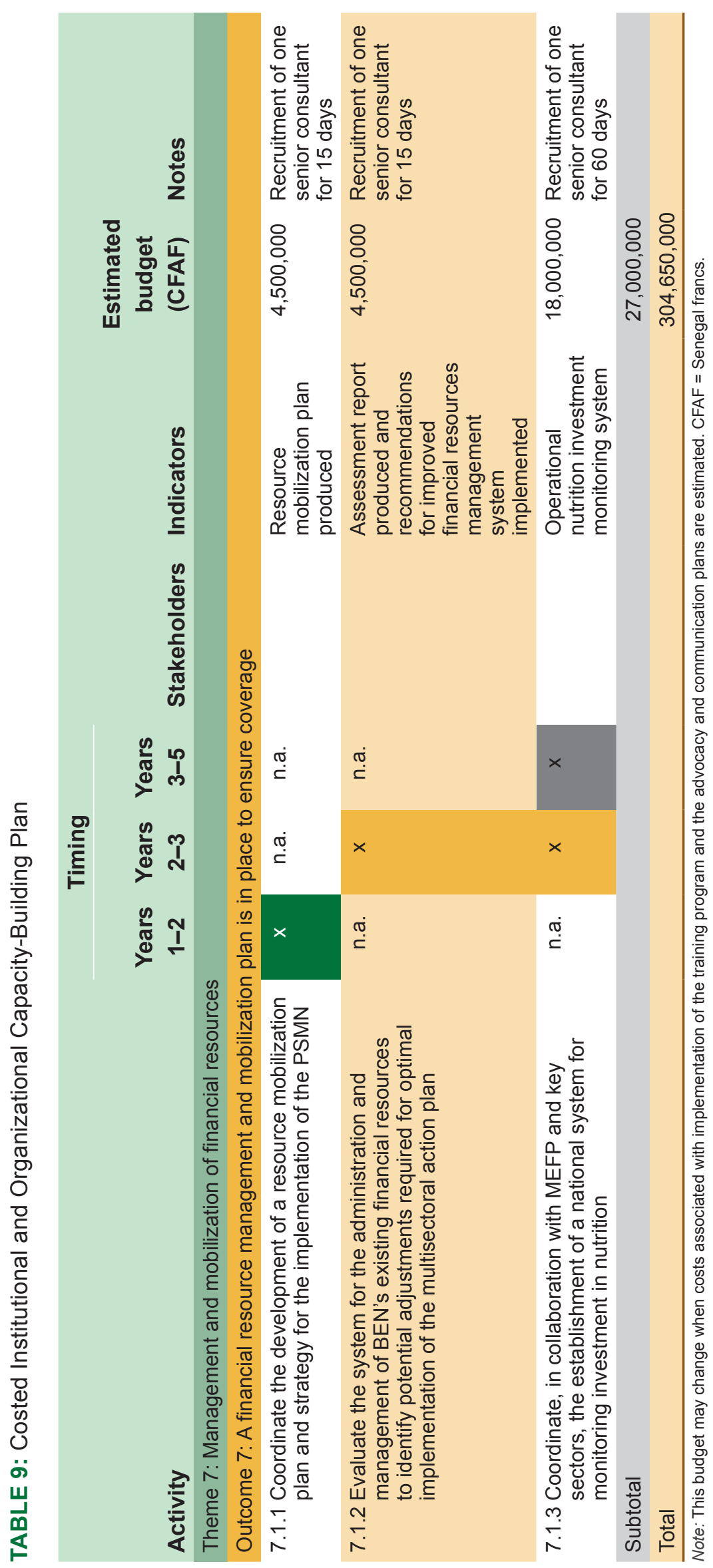




\section{APPENDIX A List of Recommendations by Chapter}

\section{Institutional environment of the Nutrition Sector}

Enhance the visibility of nutrition in the political discourse. Despite the government's efforts, nutrition is not addressed in leaders' statements, and politicians do not seem to understand the visible and concrete political issues of nutrition.

Enhance the visibility of nutrition in the sectors. Due, in part, to a lack of clearly defined objectives based on an analysis of the problem by sector, there is little ownership of nutrition and no nutrition indicators are monitored at the sectoral level.

Insufficient financial and human resources are allocated for interventions in nutrition. On the strategic level, appropriation of funds for sectors key to nutrition is lacking and gives rise to two major challenges: (1) sectoral institutionalization of nutrition; and (2) strengthening of multisectorality.

Strengthening the financial stability of the CLM is essential. As long as the CLM budget is included in the investment budget, its allocations depend on political will. Although this gives the CLM the advantage of being assessed on its performance, it remains vulnerable as it evolves in an environment of uncertainty; its survival depends on political interest in policies related to nutrition issues.

Due to its institutional anchorage in the Prime Minister's office, the CLM is well positioned to lead on implementation of a multisector approach. However, CLM relies on BEN for the deployment of its mission, and currently, multisectoral coordination is not reflected in BEN's mandate. As a result, multisectoral collaboration efforts have been relegated to the sidelines at the national, regional, departmental, and local levels. It is imperative to reverse this situation by extending BEN's mandate beyond implementation of the PRN.

\section{Stakeholders of the nutrition sector}

The CLM's institutional grounding makes it a key actor for implementation of a multisectoral approach. However, the context has changed significantly since the creation of the CLM and the BEN, and today the sector needs strong leadership specifically with respect to coordination and collaboration.

Because the decree establishing the BEN focused its mandate on the PRN's implementation, and because the CLM relies on the BEN for deployment of its mission, the BEN's mandate should be expanded to increase its legitimacy. Currently, multisectoral coordination is not reflected in the mandate, and as such is relegated to the sidelines at national, regional, departmental, and local levels. Even though the BEN is implicitly working in this direction, its efforts are still inadequate and fall short of the increasingly high expectations for stronger leadership and maximum multisectorality and collaboration in the sector.

The CLM budget is included in the investment budget, and its budget allocations depend on political will. The CLM should seek to secure the continued commitment of political authorities to increase its budget allocations and government's investment in nutrition. 


\section{Stakeholder contributions (no recommendations provided)}

\section{Organizational Capacities of the Nutrition Sector}

DCMS should strengthen its structure at decentralized levels (regional and departmental) to ensure an effective presence in the field.

MEPA should redefine and align the missions and responsibilities of its different divisions to avoid duplication, increase efficiency and to address the shortage of services in the field. The decentralized technical services of MEPA do the work of four directorates, and there is a problem of translation of services because of their attachment to the Cabinet as opposed to the directorates. The hierarchical nature of MEPA's field services also poses a stumbling block. Specialists should be recruited to analyze MEPA's human resource needs and to propose an organizational chart adapted to a strategic orientation that addresses these limitations.

BEN's organizational structure should be adapted to the new challenges and expectations of the nutrition sector. Establishing new technical units (such as governance and funding) or reengineering old ones will keep BEN in line with the changing dynamics of the sector. At the regional level, the institutional communication capacities of BER technical teams must be improved.

As part of the implementation of the new strategic plan, a coordination of actors will be required. As such, it is important for the CLM to strengthen its internal coordination and to conduct a review of its actions as an institution to evaluate implementation of its mandate.

Biannual exchange meetings on nutrition interventions with TFPs should be reinstated.

DCMS must improve its coordination with the decentralized level by changing the existing ineffective mechanism.

MEPA should improve the planning of its meetings to cut their number.

DAN should continue to hold regular meetings at various levels.

To offset the lack of career development protocol, the BEN should consider strategies for talent retention. For example: continuous capacity building, recognition of staff contributions, encouragement of creativity, and internal collaboration.

BEN should systematically document human resource needs, encourage compliance with the procedural manual, and employ staff trained in human resource management or strengthen the capacities of staff members with skills in that area.

BEN should hire more personnel with skills in nutrition, specifically nutrition advocacy, network management, public-private partnerships, fundraising, governance, and data processing. BEN should finalize recruitment and deployment for all vacant posts or retrain current staff to fill these roles.

BEN should create coordination positions attached to a BER for the supervision of activities instead of leaving the BERs to cover several regions with very limited staff.

BERs should strengthen the capacities of their personnel in human resources, program management, logistics, and procurement and promote the development of nutrition capacity through short training courses, certifications, and part-time university degree programs.

DAN, through the DSRSE, should request that MSAS authorize an increase in skilled staff specializing in nutrition, public health or both, as well as staff holding expertise in policy development and communications. Simultaneously, DAN should strive to strengthen capacities of current staff (at both central and field levels) in nutrition and managerial operations (personnel, equipment, and inputs) for the CREN, and for the UREN.

DCMS should redefine the profile of its officers to better match the Division's objectives and to strengthen capacities in nutrition.

MEPA should strengthen its field staff and advocate to the government for funds to reduce its human resource gap, including recruitment of a human resource manager and strengthening of nutrition staff.

DAPSA should advocate to the government for funds to provide basic training in statistical assessment of food and nutrition security.

Under the PSMN, the CLM's budget planning tool must be reviewed so as to improve different sectors' contributions to nutrition budget planning for BERs.

Heads of nutrition departments and divisions within line ministries and CLM focal points should continue to advocate to the relevant authorities to mainstream nutrition and to allocate sufficient resources to related activities.

Improve the control of budgets assigned to state services. For example, the DCMS should advocate for the mainstreaming of nutrition indicators in the PAQUET-EF during the MEN's budget allocation review of program documents.

BEN should systematize budget orientation sessions for partners receiving CLM funding and involve the TFPs in the planning of BEN interventions.

BEN should share with the BERs all information on agreements signed and commitments made with other sectors. BEN and BERs should set up formal frameworks to share and plan activities rather than relying on those carried out on an ad hoc basis. 
(continued)

DCMS, DAPSA, MEPA, and DAN should expand their planning to other departments in their ministries and to partners to enhance synergies and build on experience.

BEN should use monitoring and assessment software to improve its data presentation.

To avoid duplication of effort in health districts, BEN and DAN should harmonize indicators and data gathering tools to facilitate the work of health personnel and improve the use of community data by health facilities.

BEN should evaluate impact as well as/instead of outcome indicators and disseminate the assessment results.

DAN should, in cooperation with other stakeholders, focus on improving the monitoring and assessment of nutrition indicators at the region and district levels.

All units of analysis should focus on staff training in monitoring and assessment.

DCMS and DAPSA should each set up a monitoring and assessment system in line with the PMSN.

Efforts should be made to create mechanisms for data and information sharing between the units of analysis.

BEN and the CLM should develop a digital communication strategy that updates their websites and raises nutrition sector visibility; sector visibility should also be increased through advertisements, television documentaries, and press packs.

BEN and BERs should increase visibility at the regional level through radio programs on nutrition.

"Nutrition tours" with the regional, national, and international media and open house events would increase the public's awareness of nutrition issues.

DCMS should improve its visibility by promoting its health and nutrition activities and by better engaging the DPRE and communicating with other MEN divisions and departments.

DAN should improve its visibility by implementing its media communication plan and by working in close collaboration with DSRSE's communication unit and SNEIPS. DAN and the CLM should also work together to develop the capacities of health journalists.

The CLM should revise the terms of reference of its members, clearly defining their roles in relation to their respective sectors, other CLM members, and the CLM itself.

The CLM should raise the profile of its sectoral focal points and facilitate their roles as nutrition champions; coaching them to use their sector-specific expertise to identify strategies to institutionalize nutrition, and by placing appropriate communication tools at their disposal.

The CLM must affirm its leadership in the field of nutrition and strengthen its strategic dialogue and advocacy with various sectors for the institutionalization of nutrition. It must also address its intersectoral coordination mission by creating a multisector platform that coordinates all stakeholders, meets regularly, and conducts joint monitoring actions. Such efforts would clarify roles and responsibilities and facilitate establishment of a common performance measurement framework such as sectoral reviews.

Providing a structure for TFP collaboration on nutrition (and other types of initiaves) will increase the consistency of their actions. Such a structure should be informed by sectoral reviews, which foster accountability and improve complementarity between programs.

Within the nutrition sector, development of the PSMN increases the need to strengthen collaboration among TFPs. Pooled funding targeting common priorities must be established.

BEN should regularly take stock of its computer resources and infrastructure to establish needs and requirements.

Units of the various ministries should give priority to the preventive maintenance of computer hardware rather than addressing problems as they appear or upon demand.

Special attention should be paid by each unit to the need for functioning workspaces at central and regional levels.

\section{Organizational culture and performance incentives within the units of analysis}

The BEN should improve the control and visibility of financial resources to improve performance by urging TFPs to consider staff motivation in the provision of funding.

The BEN's employee recognition activities should be restored, for example, merit or seniority-based staff awards, letters of congratulation, certifications, and an annual staff celebration event.

The CLM should improve its reimbursement of work-related expenses, such as transportation costs, currently paid by staff.

Ministerial entities should raise salaries, improve the timeliness of overtime renumeration, grant performance-based bonuses, and introduce risk bonuses when appropriate.

Staff enrichment activities within the BEN and BERs should be introduced, for example study trip and training opportunities. BER officials should be permitted to use corporate vehicles for professional purposes, including after regular working hours when necessary, amending the manual of procedures if necessary. 
(continued)

To boost staff morale, the BEN and BERs should create opportunities for socialization.

To enhance its attractiveness, MEPA should improve working conditions and increase salaries and benefits.

DCMS should enhance staff motivation measures by strengthening capacity and increasing allowances.

DAN should improve its working environment by creating opportunities for socialization and equipping the division with basic amenities.

\section{Organizational performance of the units of analysis}

The BEN's mission should be revised to better align with the reality that has developed over time and with practical experience: That is, the BEN now functions as the operational arm of the CLM. As such, it plays a critical role in the execution of the CLM's mission, holding responsibilities that extend beyond the functions it was assigned 15 years ago.

More systematic collection of information by the BEN on beneficiary satisfaction would enhance program efficiency.

CLM and relevant partners should work to improve communication on the impressive effectiveness of nutrition investments to enhance sector visibility and increase stakeholder trust.

CLM and relevant partners should strengthen multisectoral collaboration through a multisectoral platform that is operational at the national, regional, departmental and grassroots levels to improve harmonization of planning and efficient use of resources; a critical component of such a platform would be a monitoring and assessment system for the collection and sharing of nutrition-related information, and a clarification of the roles and responsibilities stakeholders.

CLM should commission an analysis of the nutritional situation that defines a common vision of problems and solutions and clarifies relevant sectors' roles, and calls explicitly for better mobilization of resources.

CLM and relevant partners should increase advocacy for academic training to educate a critical mass of nutritionists nationwide.

To reduce vulnerability and increase donor harmonization, a budgeted nutrition action plan which includes evidence-based resource mobilization strategies, should be developed. This plan should take available funding into account and also target additional external and internal resources (including government and CLs as well as TFPs).

A multisectoral action plan is essential to harmonize and coordinate nutrition sector investments.

\section{Strengths and obstacles in the nutrition sector in Senegal (no recommendations provided)}

\section{Guidelines for strengthening institutional and organizational capacity within Senegal's nutrition sector}

The guidelines in this concluding chapter provide a summary of the recommendations listed above, and also link them to the costed institutional and organizational capacity-building plan (table 10). 


\section{APPENDIX B Interview and Focus Group Participants}

\section{Individual Interviews}

\begin{tabular}{|c|c|c|}
\hline Name & Position/Structure & Email \\
\hline Momar Talla Gueye & Director of Research and Development/ITA & $\begin{array}{l}\text { gueyemt@gmail.com } \\
\text { mtgueye@ita.sn }\end{array}$ \\
\hline Oumar Diouf & FAO National Coordinator (Pro-Act) & oumar.diouf@fao.org \\
\hline Bocar Mamadou DAFF & Director DSRSE & bmdaff@gmail.com \\
\hline Sophie Cowppli-Bony & Facilitator International REACH & sophie.cowppli-bony@wfp.org \\
\hline Abdoulaye Ka & National Coordinator BEN/CLM & aka@clm.sn \\
\hline Mahamadou Traoré & Senior Physician Medical Region of Fatick & mohamed_traore2001@yahoo.fr \\
\hline Babacar Diouf & Head of Regional Trade Service/Fatick & srcfatick@gmail.com \\
\hline Safietou Ba Diop & Technical Adviser Social Protection Delegation & basafietou@yahoo.fr \\
\hline Cheikh Ahmadou Lo & Representative Afrique GAIN & calo@gainhealth.org \\
\hline Ndeye Fatou Ndiaye & Coordinator of COSFAM for ITA & nfndiaye@ita.sn \\
\hline Aminata Ndiaye Coly & Nutritionist BACDI & aminata.ndiaye@bacdi.org \\
\hline Laylee Moshiri & UNICEF Country Representative & Imoshiri@unicef.org \\
\hline Georges Fom Ameh & Head of Survival Programme UNICEF & Gameh.@unicef.org \\
\hline Aissatou Dioum & Nutrition Specializt UNICEF & \\
\hline Mouhamadou Guélaye Sall & Pediatrician/Pediatric Ward, Hôpital Le Dantec & mgsall@gmail.com \\
\hline Salif Signaté & Economist Planner/DP DGPPE MEFP & signatezal@yahoo.fr \\
\hline Sophie Guèye Sow & $\begin{array}{l}\text { Director Health Nutrition and Community } \\
\text { Approach/Agence Nationale de la Petite Enfance } \\
\text { et de la Case des Tout-Petits (National Agency } \\
\text { of Early Childhood Development and Reception } \\
\text { Center) (ANPECTP) DSNAC }\end{array}$ & sowsophiegueye@yahoo.fr \\
\hline Balla Moussa Diedhiou & Director Sahel/Micronutrient Initiative & bdiedhiou@micronutrient.org \\
\hline
\end{tabular}

(continued on next page) 
(continued)

\begin{tabular}{|c|c|c|}
\hline Name & Position/Structure & Email \\
\hline Rama Aïdara & Economic Surveys Commissioner & ramaidara@gmail.com \\
\hline Mame Diarra Loum & Fisheries Engineer/DPM & loum.mamediarra@gmail.com \\
\hline Ndèye Mayé Diouf & Program Officer/MEFP/DCEF & mayediouf@hotmail.com \\
\hline Megan Kyles & Ag Nutrition /USAID & mkyles@usaid.gov \\
\hline Mamadou Diallo & $\begin{array}{l}\text { Deputy Head of Animal Breeding Service } \\
\text { Tambacounda }\end{array}$ & gandomamadou@gmail.com \\
\hline Samba Ndao & $\begin{array}{l}\text { Head of Regional Agricultural Service/ } \\
\text { Tambacounda }\end{array}$ & drdrtamba@yahoo.fr \\
\hline Khadim Ndiaye & Head of Regional Trade Service, Tambacounda & servicecommercetamba@gmail.com \\
\hline Habib Ndiaye & Senior Physician/Tambacounda Medical Region & ndiaye_abib@yahoo.fr \\
\hline Guéno Seck Camara & National Food Security Council & guenoseck@secnsa.sn \\
\hline Abdou Khadre Diop & $\begin{array}{l}\text { Deputy Governor in charge of Development/ } \\
\text { Tambacounda }\end{array}$ & khadre114@yahoo.fr \\
\hline Abdoulaye Thiam & $\begin{array}{l}\text { HKI } \\
\text { Country Director }\end{array}$ & athiam@hki.org \\
\hline Demba Toure & Prefect Koumpentoum Department & ddemba20@yahoo.fr \\
\hline Sidy Coulibaly & $\begin{array}{l}\text { Head of Planning/Agence de Développement } \\
\text { Régional (Regional Development Agency) (ARD) } \\
\text { Tambacounda }\end{array}$ & estsidy@yahoo.fr \\
\hline Elimane Ba & Prefect of Gossas & prefecturegossas@hotmail.com \\
\hline Maria Eugenia Garcia Noguera & $\begin{array}{l}\text { Humanitarian Programs Officer/Agence } \\
\text { Espagnole pour la Coopération Internationale } \\
\text { et le Développement (Spanish Agency for } \\
\text { International Co-operation and Development) } \\
\text { (AECID) }\end{array}$ & meugenia.garcia@aecid.es \\
\hline Anna Bergeot & European Union & anna.bergeot@eeas.europa.eu \\
\hline Moussa Mbaye & CEP/MEPA Coordinator & msbaye58@yahoo.fr \\
\hline Massamba Ndiaye & ABR/CLM Tambacounda & \\
\hline Menno Mulder-Sibanda & World Bank & mmuldersibanda@worldbank.org \\
\hline
\end{tabular}

\section{Group interviews}

\section{BEN}

\begin{tabular}{lll} 
Name & Position/Structure & E-Mail \\
\hline Malick Faye & RFC-BEN/CLM & mfaye@clm.sn \\
\hline Maurice Ndour & RAL-BEN/CLM & mndour@clm.org \\
\hline Ousseynou Diakhaté & CHC-BEN/CLM & odiakhate@clm.sn \\
\hline Ndèye Khady Touré & CMN-BEN/CLM & nndiaye@clm.sn \\
\hline El Hadji Momar Thiam & RSE-BEN/CLM & ethiam@clm.sn \\
\hline Aminata Ndoye & RPO-BEN/CLM & andoye@clm.sn \\
\hline Fatou Thiam & GPP-BEN/CLM & fthiam@clm.sn \\
\hline Christian V. Thiemon & CPP-BEN/CLM & cthiemon@clm.sn \\
\hline Astou NG. Diop & COS-BEN/CLM & andaw@clm.sn \\
\hline Adama Cissé Ndiéguène & Communication-BEN/CLM & acisse@clm.sn \\
\hline
\end{tabular}




\section{DAN}

\begin{tabular}{lll} 
Name & Position/Structure & E-Mail \\
\hline Maty Diagne Camara & Head of Division/DAN & matydiagne@yahoo.com \\
\hline Adjiratou Sow Diallo & Head of S\&E & mamydiallo2@yahoo.fr \\
\hline Rokhy Dramé Diallo & C/SR-DSMNN/DSRSE & dabainsa@yahoo.fr \\
\hline Ndèye Mossane Ndour & $\begin{array}{l}\text { Midwife-Division de la Survie de l'Enfant } \\
\text { (Division of Child Survival) (DSE)/DSRSE }\end{array}$ & mossane72@yahoo.fr \\
\hline Marie Louise Gaye & TSS in Nutrition-DAN/DSRSE & marielougaye2000@yahoo.fr \\
\hline Agnès Ndiaye & DSE/DAN & agnesgoudiaby@yahoo.fr \\
\hline Abdoulaye Guèye & SP Nutrition Intern-DAN/DSRSE & adoublayegueye@gmail.com \\
\hline
\end{tabular}

\section{DCMS}

\section{Name}

Mor Diaw

Fatou Sabelle Diop

Sira BA

Ibrahima Ciss

Salimata Mbodji Sene
Position/Structure

Head of Division DCMS/MEN

Nutritionist DCMS/MEN

DEPS/MEN

DPRE/MEN

DEMSG/MEN

\section{E-Mail}

diawmor@hotmail.com

fasabelle@hotmail.com

siraba1@gmail.com

ciss_ibrahima@yahoo.fr

sallsenma@yahoo.fr

\section{BER of Thiès}

\section{Name}

Nene Hawa SY

Ndeye Rokhaya Seck

Astou Diakhate

Modou Mostapha Faye

\section{Position/Structure}

RBR/BER Thiès

Program Officer /BER Thiès

Finance/BER Thiès

Finance/BER Thiès

\section{E-mail}

nsy@clm.sn

rseck@clm.sn

adiakhate@clm.sn

modoufaye@clm.sn

\section{AEC Tambacounda (Child Fund, Caritas, CRS)}

\begin{tabular}{lll} 
Name & Position/Structure & E-Mail \\
Mame Balla Dieng & Account Administrator Africare & mdieng@africare.org \\
Amadou Bassirou Diawara & Projet Manager Africare & bdiawara@africare.org \\
Madeleine Hélène Cécile Coly & Area Manager Africare & mcoly@africare.org \\
Maurice Bonang & PRN/CRS Focal Point & maurice.bonang@crs.org \\
Etienne Yatte & Project Manager CRS/Caritas & etienne.yatte@caritastamba.org \\
\hline
\end{tabular}

\section{AEC Fatick (World Vision International)}

\begin{tabular}{lll} 
Name & Position/Structure & E-Mail \\
Paul Waly Diouf & $\begin{array}{l}\text { Project Coordinator Vision du Monde } \\
\text { (World Vision International) (WVI) }\end{array}$ & paul_waly_diouf@wvi.org \\
Ndèye Yacine Gassama & Health Supervisor WVI & ndeye_yacine_gassama@wvi.org \\
\hline $\begin{array}{l}\text { Stéphane Bop } \\
\text { Wilfrid Houedjissin }\end{array}$ & Health Supervisor WVI & stephane_bop@wvi.org \\
Marie Jeanne Tine & Accountant & wilfrid_houedjissin@wvi.org \\
\hline
\end{tabular}




\section{AEC Gossas Association Régionale des Agriculteurs de la Région (Regional Association of Fatick Farmers) (ARAF)}

\begin{tabular}{lll} 
Name & Position/Structure & E-Mail \\
Cheikh Sèye & Accountant AEC ARAF/Gossas & seye_cheikh@hotmail.fr \\
Waly Faye & Secretary General AEC ARAF/Gossas & wakaangou@yahoo.fr \\
Ibrahima Diallo & Project Manager AEC ARAF/Guinguinéo & idsagna@yahoo.fr \\
\hline Mamour Mbodji & Project Manager AEC ARAF/Gossas & mamour.mbodji@gmail.com
\end{tabular}

Action contre le Fain (Action Against Hunger) (ACF)

$\begin{array}{lll}\text { Name } & \text { Position/Structure } & \text { E-Mail } \\ \text { Fabrice Carbonne } & \text { Country Director /ACF } & \text { fcarbonne@sn.acfspain.org } \\ \text { Sandrine Busière } & \text { Medico-Nutrition Coordinator/ACF } & \text { sbusiere@sn.acfspain.org }\end{array}$

\section{Croix Rouge Française (French Red Cross) (CRF)}

\begin{tabular}{lll} 
Name & Position/Structure & E-Mail \\
\hline John Mubalama & Country Director/CRF & Hod-senegal.frc@croix-rouge.fr \\
Magloire Bunkembo Mampindou & Health Coordinator/CRF & sante-senegal.frc@croix-rouge.fr
\end{tabular}

\section{Ministry of the Environment and Sustainable Development/ \\ Ministry of Hydraulics and Sanitation}

\begin{tabular}{lll} 
Name & Position/Structure & E-Mail \\
\hline Mame Sokhna Ndiouck & Environmentalist MEDD/DEEC & nmamesoxna@yahoo.com \\
Maïmouna Dione Diarra & Project Manager Sanitation Directorate & maidione2001@yahoo.fr
\end{tabular}

\section{Nutrition Laboratory/UCAD}

\begin{tabular}{lll} 
Name & Position/Structure & E-Mail \\
\hline Nicole Dossou & Maître de Conférences/Labo Nutrition/UCAD & nicole.dossou@ucad.edu.sn \\
\hline Adama Diouf & Nutritionniste/Labo Nutrition/UCAD & adama.diouf@ucad.edu.sn
\end{tabular}

\section{Koumpentoum Decentralized Services}

\begin{tabular}{lll} 
Name & Position/Structure & E-Mail \\
Papa Anoune Sall & $\begin{array}{l}\text { Head of Service/Animal Breeding } \\
\text { Koumpentoum }\end{array}$ & papaanounesall@yahoo.fr \\
\hline Landing Diedhiou & $\begin{array}{l}\text { Head of Service/Service Départemental } \\
\text { d'Appui au Développement Local } \\
\text { (Departmental Local Development Support } \\
\text { Service (SDADL) }\end{array}$ & dingdiedhiou@yahoo.fr \\
\hline Cheikh Tidiane Sy & $\begin{array}{l}\text { Chef de Service/Service Départemental de } \\
\text { l'Action Sociale (Departmental Service for } \\
\text { Social Action) (SDAS) }\end{array}$ & cheikhtidianesyc11@yahoo.fr \\
Ndiama Badara Sadio & $\begin{array}{l}\text { Chef de Service/ Service Départemental du } \\
\text { Développement Rural (Departmental Service } \\
\text { of Rural Development) (SDDR) }\end{array}$ & ndibada@yahoo.fr \\
\hline Abdoulaye Faye & $\begin{array}{l}\text { Major Point Focal Malnutrition/Centre de } \\
\text { Santé Koumpentoum }\end{array}$ & abdoulayefaye909@gmail.com \\
\hline
\end{tabular}


Fatick Decentralized Services

\begin{tabular}{lll} 
Name & Position/Structure & E-Mail \\
Boubacar Diallo & Head of Regional Agriculture Service Fatick & drdrfatick@yahoo.fr \\
Ismaïla Diop Ndiaye & Regional Coordinator ANPECTP & ismailadiopndiaye@gmail.com \\
Aliou Sène & Head of Regional Action Service & bendiogoye@yahoo.fr \\
\hline
\end{tabular}

\section{Gossas Decentralized Services}

\begin{tabular}{lll} 
Name & Position/Structure & E-Mail \\
Hamath DIALLO & Inspector of Education IEF & macelkara@yahoo.fr \\
\hline Sadio DIAKHATE & $\begin{array}{l}\text { Head Departmental Community Development } \\
\text { Service C/SDDC }\end{array}$ & Sadiodiakhate75@gmail.com \\
\hline Fallou NDOUR & Head of SDEL & reelmousa@gmail.com \\
Moustapha SARR & $\begin{array}{l}\text { Health Care Supervisor PriMayor of Health, } \\
\text { District of Gossas }\end{array}$ & Moustapha.sarr@yahoo.fr \\
\hline
\end{tabular}

\section{Private Sector (Dakar)}

\begin{tabular}{lll} 
Name & Position/Structure & E-Mail \\
Maguette Ndioum & Chairman, Management Committee of Lac & maxndioum@hotmail.fr \\
& Rose/APISI UEMOA & \\
Boulaye Camara & Director of Operations SUNEOR & bcamara@suneor.sn \\
Fatoumata Doucoure Dia & Quality control officer NMA Sanders & fatoumata.doucoure@nmasanders.com \\
Aliou Diouf & Quality-Security-Environment Officer/ & aliou.diouf@copeol.com \\
& OLESEN & \\
\hline
\end{tabular}

\section{Local NGOs (Dakar)}

\begin{tabular}{lll} 
Name & Position/Structure & E-Mail \\
\hline Emmanuel Seyni Ndione & Executive Secretary Enda Graf Sahel & emmanuel.ndione@endagrafsahel.org \\
Abdou Diouf & Executive Secretary Eau-Vie-Environnement & abdoudiouf@eve-sn.org \\
Anta Sow & Programme Officer Enda Graf Sahel & anta.sow@endagrafsahel.org \\
Moussa Souane & Coordinator Kafoo/PRN Kafoo Sedhiou & kafoonutrition@yahoo.fr \\
\hline
\end{tabular}

\section{CLM}

\begin{tabular}{lll} 
Name & Position/Structure & E-Mail \\
Fatou Goumbo Guèye & Project Manager DAPSA/MAER & fagueye20032003@yahoo.fr \\
Assane Guèye & Statistician NGO APAPS CONGAD & mafary83@gmail.com \\
\hline
\end{tabular}


Interviews and Group Discussions (Authorities, Local Authorities, and Communities)

Prefecture of Gossas

\begin{tabular}{lll} 
Name & Position/Structure & Contacts \\
Elimane Ba & Prefect of Gossas & prefecturegossas@hotmail.com \\
\hline
\end{tabular}

\section{Local Government of Thiaré (Fatick)}

\begin{tabular}{ll} 
Name & Position/Structure \\
Djibril Niane & ICP \\
Sanegui Niane & Mayor, Thiaré \\
Mamadou Ngom & Councillor \\
Mamadou Faye & Councillor \\
\hline
\end{tabular}

\section{Local Government of Ndienné Lagane (Gossas)}

\section{Name}

Youssoupha Ndiaye

Cheikh Dieng

Alseyni Diop

Ngagne Dionne

Bécaye Touré

Mbaye Niang

Sidy Bara Diop

Dame Kane

Serigne Mbacké Diop

Awa Niang

Absa Dionne

Wane

Sokhna Sene

Abdou Faye

Aly Konté

Mbagnick Sene

Ndèye Sene

Aly Lo

\section{Position/Structure}

Municipal Secretary

Councillor

2nd Deputy Mayor

1st Deputy Mayor

Councillor

Councillor Pdt Com.

Councillor

Councillor

Councillor

Councillor

Councillor

Professor/ CEM Ndienné

Councillor

Councillor

Pdt Youth Com.

Councillor

Councillor

ICP

\section{Men's Focus Group, Boof Poupouye, Fatick}

\begin{tabular}{ll} 
Name & Position/Structure \\
\hline Diène Codou Faye & Trader \\
\hline Ngor Gningue & Farmer \\
\hline Esnest Gningue & Farmer \\
\hline Biram Diouf & Farmer \\
\hline Diène Faye & Farmer \\
\hline Mbassa Diouf & Farmer \\
\hline Kory Sene & Farmer \\
\hline Gorgui Faye & Herdsman \\
\hline Fata Faye & Farmer \\
\hline Wagane Faye & Farmer \\
\hline
\end{tabular}


Wome's Focus Group, Boof Poupouye, Fatick

Name

Mariama Diouf

Diarra Ndiaye

Binta Mbodji

Seynabou Marone

Ndèye Malick Dieng

Tacko Dieng

Khady Diouf

Khady Diagne

Fatou Diong

Daba Diore

Mbissine Faye

Women's Focus Group, Khaye Mbayard, Gossas

Name

Aïda Ndiaye

Kiné Ndiaye

Sokhna Diaw

Awa Faye

Awa Diop

Fatou Sarr

Khemes Guèye

Sokhna Fall

Khady Diouf

Ndèye Sarr

Khady Mbaye

\section{Men's Focus Group, Khaye Mbayard, Gossas}

\begin{tabular}{ll} 
Name & Position/Structure \\
\hline Abdou Fall & Village Chief \\
\hline Abdou Faye & Village Chief \\
\hline Coré Pouye & Notable \\
\hline Massaer Mbengue & Notable \\
\hline Coly Faye & Notable \\
\hline Samba Diop & \\
\hline Mame Modou Ndiaye & \\
\hline Gora Fall & \\
\hline Ousmane Fall & \\
\hline Djibi Ka & \\
Birame Faye & \\
\hline
\end{tabular}


Women's Focus Group, Sourouyel, Nétéboulou/Tambacounda

Name

Mariama Diallo

Aïssatou Bâ

Djiba Diao

Adja Sow

Fatoumata Bâ

Cody Dabo

Diabou Bâ

Dieynaba Diallo

Fatoumata Sidibé

Bodo Kairé

Haby Dianka

Khadidiatou Diao

Djiba Mané

Oumou Soumaré

Kadiatou Touré

Aïssatou Diallo

\section{Local Government of Nétéboulou, Tambacounda}

\begin{tabular}{ll} 
Name & Position/Structure \\
\hline Issa Signaté & Mayor de la Commune \\
\hline Diamé Diaby & City Councillor \\
\hline Mamadi Dansokho & City Councillor \\
\hline Fousseyni Dembelé & City Councillor \\
\hline Ckeikh Hamidou Sy & City Councillor \\
\hline Olivier Sambou & ICP \\
\hline Diamé Doumbouya & Notable \\
\hline Mady Cissao & \\
\hline Fatoumata Signaté & Relais communautaire (Volunteer community health worker) \\
\hline Aïssatou Niamthio Dembelé & Relais communautaire \\
\hline Aminata Keïta & Relais communautaire \\
\hline Alicouran Camara & Relais communautaire \\
\hline
\end{tabular}


Local Government of Koumpentoum

\section{Name}

Diouma Sow

Khop Doumbouya

Gorgui Diouf

Cheikh Sy

Djibril Coulibaly

Ousmane Bâ

Mamadou Diallo

Ndiaga Kébé

Sello Gadiaga

Selly Kane

Ablaye Bâ

Alioune Diallo

Lansana Traoré

Khady Mbaye

Oumar Traoré

Malick Ndao

\section{Position/Structure}

Councillor

Councillor

Neighborhood representative

City Councillor

City Councillor

Notable

City Councillor

Neighborhood Chief

Notable

Mayor

Imam

Délégué de quartier (Neighborhood delegate)

Délégué de quartier

Secretary

Secretary

Village chief

\section{Women's Focus Group, Koumpentoum}

\section{Name}

Fatou Ndiaye

Daba Bâ

Binta Diao

Khady Faye

Hawa Thiam

Adama Thiam

Mbollo Yatte

Fatoumata Ndiaye

Yama Ndao

Faty Bâ

Coumba Diallo

Astou Mbacké

Aïssatou Niang

Awa Niang

Awa Cissé

Fatou Guèye

Marème Thiam

Siré Diouma Diallo

Maguette Samb

Ndella Thiam

Aïssatou Sall

Aïssatou Ndao 


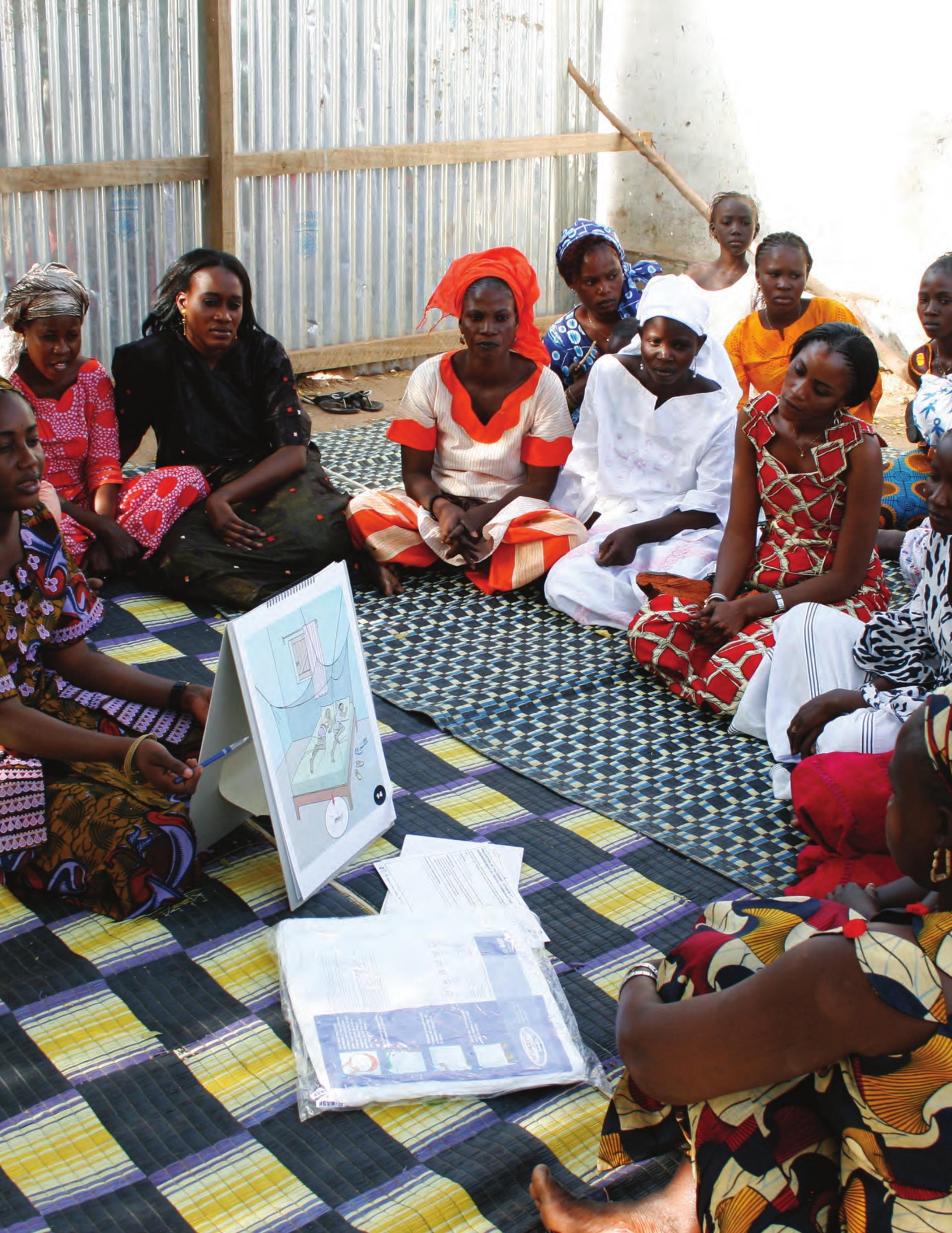




\section{Endnotes}

1. The PNDN is referred to in earlier reports as "Document de Politique Nationale de Développement de la Nutrition (DPNDN)

2. While collectivités locales was the correct usage at the time this report was written, decentralized entities are currently referred to as collectivités territoriales
3. Based on the approach described by Lusthaus et al. (2003).

4. Recruitment of new staff was also reported to be underway at the time this assessment was conducted.

5. See Spray (2018) for additional details on PRN.

6. Based on budget data from MAER (2014). 



\section{References}

ANSD (National Statistics and Demography Agency). 2012, 2016. 2013. 2014. 2016.

CLM (Unit for the Fight against Malnutrition).2006 PRN Phase II Implementation Manual. Dakar, Senegal: CLM.

Funding Synthesis Document (2004-2015). Dakar, Senegal: CLM.

2015. Financial Monitoring Report $n^{\circ} 35\left(1^{\text {st }}\right.$ July-30 September 2015), November 2015. Dakar, Senegal: CLM.

Date not available.. Qualitative Study of the Determinants of Malnutrition at Community Level. Dakar, Senegal: CLM.

DSRSE. Institutional and Organizational Diagnostic Report 2014.
IFPRI (International Food Policy Research Institute). 2016. Global Nutrition Report 2016: From Promise to Impact: Ending Malnutrition by 2030. Washington, DC: IFPRI.

Lusthaus, C., M.-H. Adrien, G. Anderson, F. Carden, and G. Plinio Montalván. 2003. Organizational Assessment: A Framework for Improving Performance. Ottawa, Canada: International Development Research Center.

MAER (Ministry of Agriculture and Rural Equipment). 2015. Performance report for 2014. Dakar, Senegal: MAER.

2016. Annual Performance Project (PAP). Dakar, Senegal: MAER.

MEN (Ministry of Education). 2014. Dakar, Senegal:MEN.

MSAS (Ministry of Health and Social Affairs). 2013. Financial Report 2009-2012.

Nene, Marc. 2017. "Nutrition Situation in Senegal." Analysis \& Perspective: 15 Years of Experience in the Development of Nutrition Policy in Senegal. 
Washington, DC: World Bank; Dakar, Sénégal: CLM.

Offosse N., M-J. 2018. "Nutrition Financing in Senegal." Analysis \& Perspective: 15 Years of Experience in the Development of Nutrition Policy in Senegal. Washington, DC: World Bank; Dakar, Sénégal: CLM.

Ruel-Bergeron, J. 2017. "The Case for Investment in Nutrition in Senegal." Analysis \& Perspective: 15 Years of Experience in the Development of $\mathrm{Nu}$ - trition Policy in Senegal. Washington, DC: World Bank; Dakar, Sénégal: CLM.

Spray, A.L. 2018. "Evolution of Nutrition Policy in Senegal." Analysis \& Perspective: 15 Years of Experience in the Development of Nutrition Policy in Senegal. Washington, DC: World Bank; Dakar, Sénégal: CLM.

WHO. 2017. Children: Reducing Mortality (database) World Health Organization, Geneva, Switzerland http://www.who.int/mediacentre/factsheets/fs178/fr/. 


\section{WORLD BANK GROUP}

1818 H Street, NW

Washington, DC 20433

Funding for the report was provided by UNICEF, the World Bank and the Japanese Trust Fund for Nutrition.
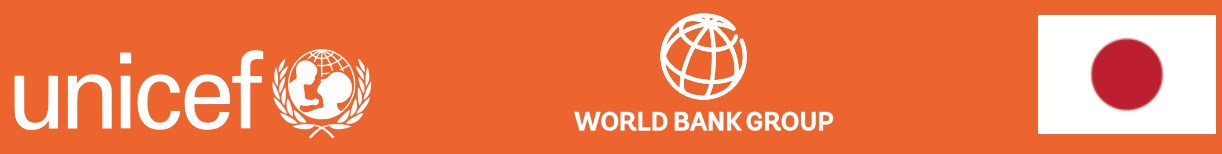

Le groupe de travail qui a supervisé la série était composé de membres des organisations suivantes:
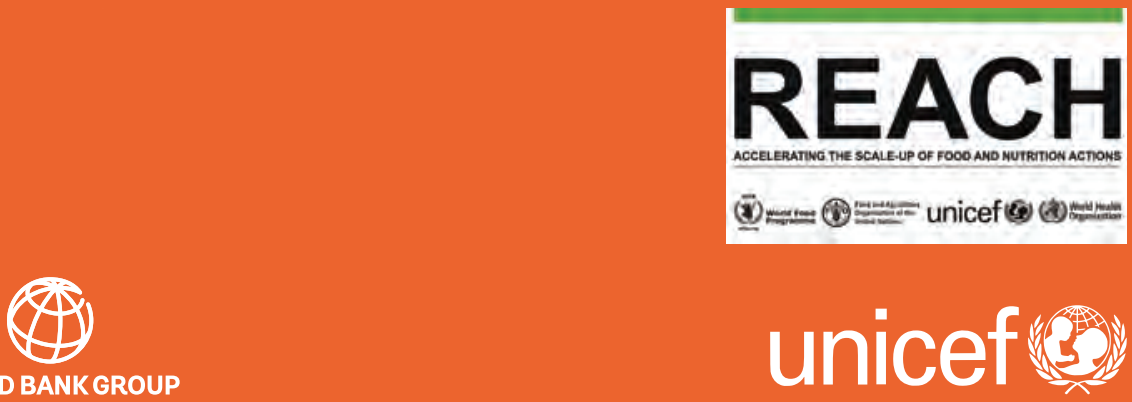